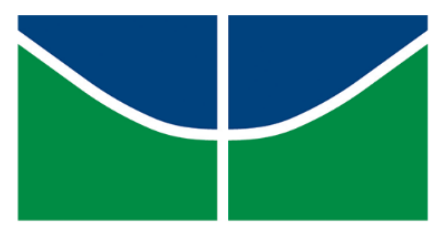

Universidade de Brasília

Instituto de Biologia

Pós-Graduação em Biologia Microbiana

\title{
CARACTERIZAÇÃO PARCIAL DE MANANASES PRODUZIDAS POR Clonostachys byssicola CULTIVADO EM CASCA DE SOJA
}

\section{DIANDRA ALBUQUERQUE LOPES COSTA}




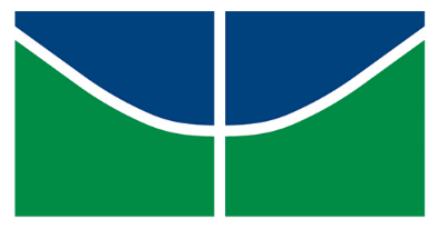

Universidade de Brasília

Instituto de Biologia

Pós-Graduação em Biologia Microbiana

\section{DIANDRA ALBUQUERQUE LOPES COSTA}

Orientador: Prof. Dr. Edivaldo Ximenes Ferreira Filho

Dissertação apresentada ao programa de Pós-

Graduação em Biologia Microbiana da

Universidade de Brasília como parte dos requisitos para obtenção do Título de Mestre.

Brasília-DF, fevereiro de 2017. 


\title{
CARACTERIZAÇÃO PARCIAL DE MANANASES PRODUZIDAS POR Clonostachys byssicola CULTIVADO EM CASCA DE SOJA
}

\section{DIANDRA ALBUQUERQUE LOPES COSTA}

\author{
Banca Examinadora: \\ $\checkmark$ Profa. Dra. Janice Lisboa de Marco \\ $\checkmark$ Prof. Dr. Carlos André Ornelas Ricart \\ $\checkmark$ Prof. Dr. Luis Henrique Ferreira do Vale
}

Prof. Dr. Edivaldo Ximenes Ferreira Filho - Orientador 


\section{AGRADECIMENTOS}

A Deus..

"Por tudo o que tens feito, por tudo que vais fazer, por tuas promessas e tudo que és eu quero te agradecer por todo o meu ser..."

Ao meu esposo, Wilmar, que sempre me apoiou e me incentivou a seguir em frente com meus objetivos. Por acreditar que sou capaz, por me acompanhar em momentos difíceis, por tolerar meus defeitos e minhas ansiedades, por me entender.... Obrigada, pois mesmo não podendo estar com você, durante a semana, você me fazia sentir segura e não me deixou desistir. Não existem palavras que possam expressar tamanha gratidão por você!

Aos meus pais, Antônio e Emiliana, por terem me proporcionado condições para seguir meus objetivos. O que seria de mim sem vocês? Como eu sou grata por ter pais tão atenciosos, mesmo em condições difíceis, vocês sempre lutaram por mim. Eu não seria nada sem vocês. Vocês são meus maiores exemplos de vida!

Aos meus irmãos, Veri, Jonatas e Diego, “especiais” da minha vida!

Ao meu orientador, Prof. Dr. Edivaldo Ximenes, por ter me aceitado e me orientado até aqui, pela paciência e por todos os ensinamentos, muito obrigada!

Aos meus colegas do laboratório: Antonielle, Andreza, Alonso, Allison, Babi, Caio, Carol, Fran, Guilherme, Helder, Leonora, Raissa, agradeço pelos momentos divertidos, pelas companhias de almoço, pelos momentos de gula, vocês são muito divertidos!

Em especial agradeço pelos ensinamentos do Helder, Caio, Antonielle, Raissa e Andreza. Obrigada por terem tirado um tempo de vocês para me ajudar, sempre que eu precisei. Por guardarem minhas amostras, por desligarem a bomba da cromatografia nos finais de semana, por olharem meus géis, por aplicarem minha amostra em coluna cromatográfica, quando eu estava em período de aula, por serem tão legais! 
Aos membros da banca examinadora (Janice Lisboa, Carlos André e Luis Henrique) por terem aceito meu convite e pelas colaborações durante minha qualificação, vocês acrescentaram muito no meu trabalho.

Às técnicas do laboratório, Magal e Marísia, pelo suporte.

Ao professor Thomas Christopher, por disponibilizar o HPLC e estar sempre disponível para nos ajudar.

A todos aqueles que, de alguma forma, contribuíram para o meu trabalho. Muito obrigada! 


\section{APOIO FINANCEIRO}

Esta pesquisa foi desenvolvida com o apoio financeiro da CAPES, CNPq e FAPDF. 


\section{SUMÁRIO}

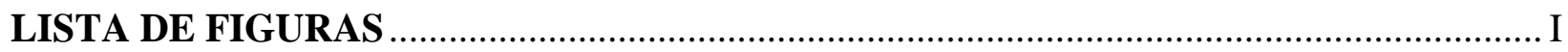

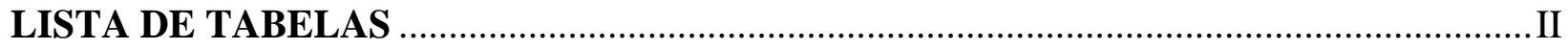

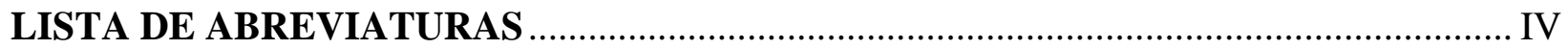

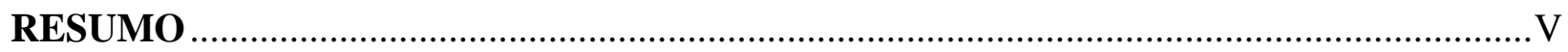

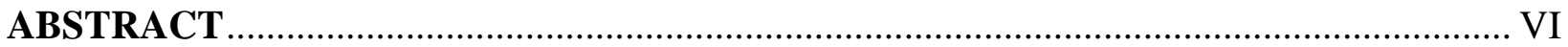

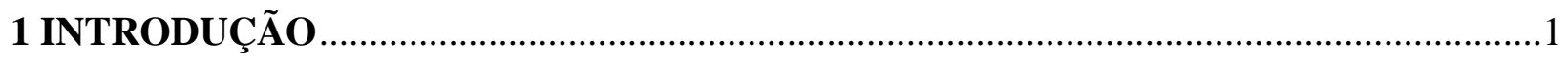

1.1 COMPOSIÇÃO DA PAREDE CELULAR VEGETAL ................................................2

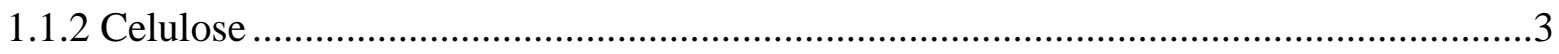

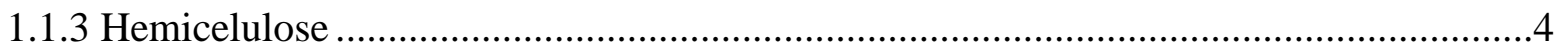

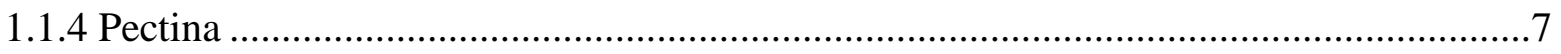

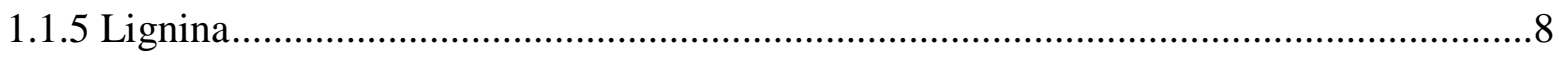

1.2 ENZIMAS QUE DEGRADAM A BIOMASSA LIGNOCELULÓSICA .........................9

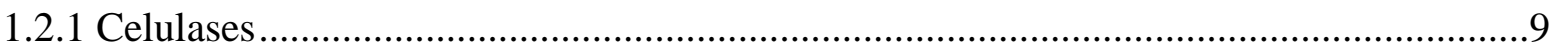

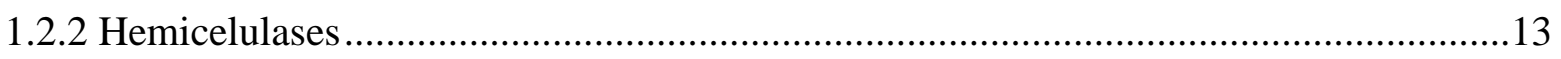

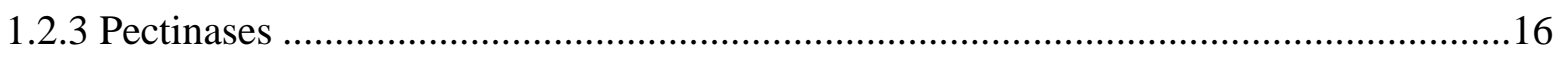

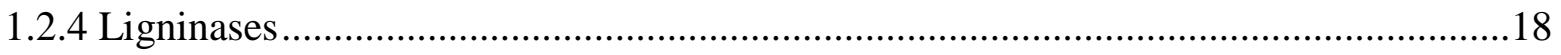

1.3 APLICAÇÃO INDUSTRIAL DE MANANASES .......................................................19

1.3.1 Redução da viscosidade de extratos de café ............................................................20

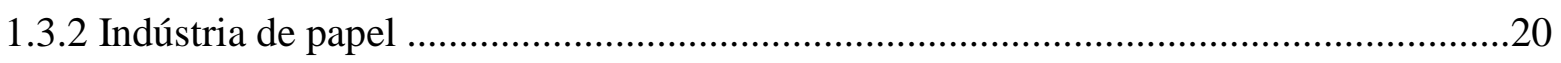

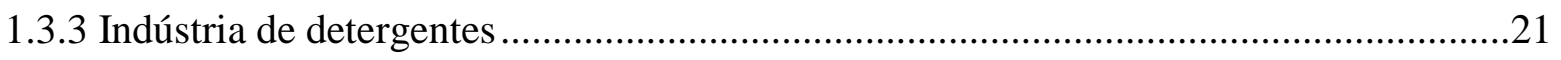

1.3.4 Mananases como aditivos de rações de animais....................................................21

1.3.5 Indústria farmacêutica e de alimentos ..................................................................22

1.3.6 Produção de etanol de segunda geração .............................................................22

1.3.7 Extração de óleo de coco .....................................................................................23

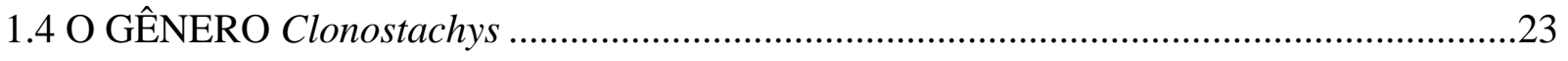

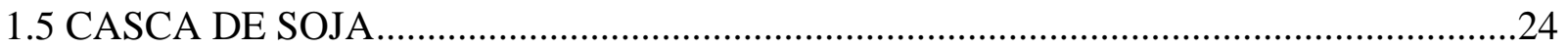

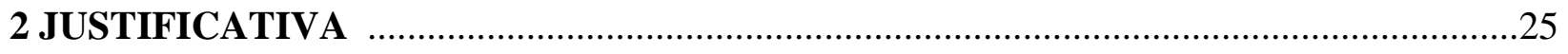




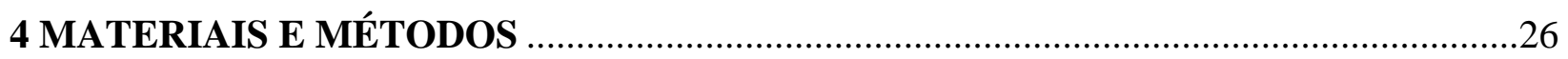

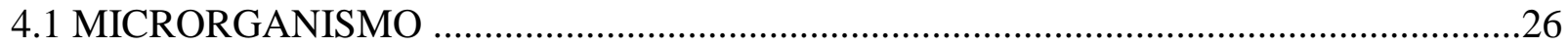

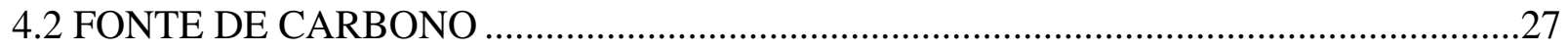

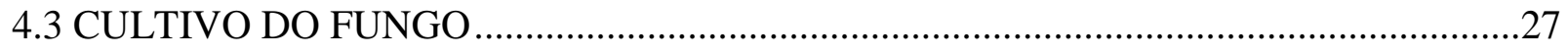

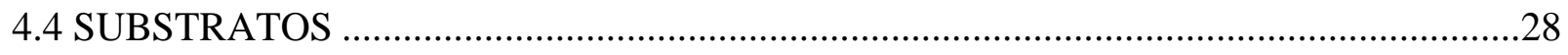

4.5 DETERMINAÇÃO DA ATIVIDADE ENZIMÁTICA E CONCENTRAÇÃO PROTEÍCA

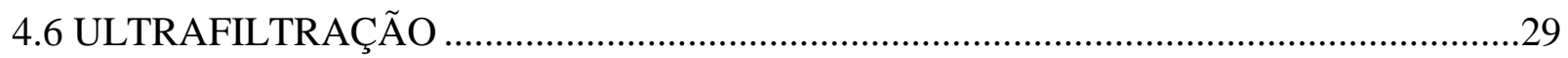

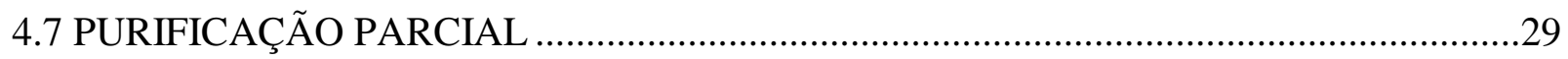

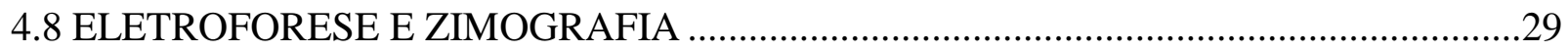

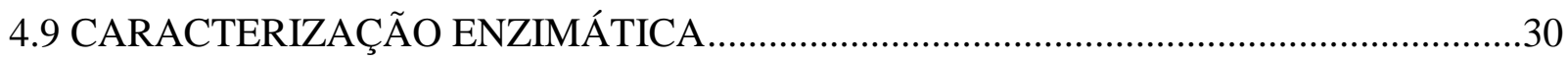

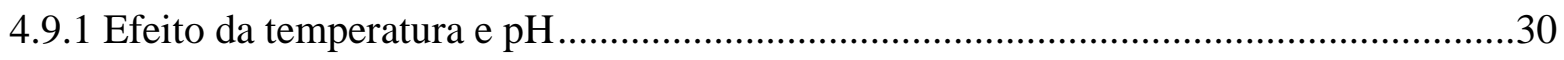

4.9.2 Avaliação da termoestabilidade .................................................................................

4.9.3 Determinação dos parâmetros cinéticos .....................................................................

4.9.4 Efeito de íons metálicos e EDTA na atividade de mananase ..........................................31

4.9.5 Efeito de compostos fenólicos na atividade de mananase .............................................32

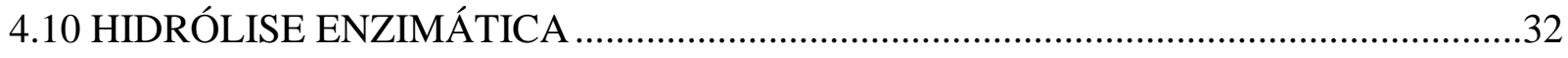

4.10.1 Análise por HPLC das amostras do ensaio de hidrólise …………………..................32

4.11 ESQUEMA DA PURIFICAÇÃO PARCIAL DE MANANASE PRODUZIDA POR $C$.

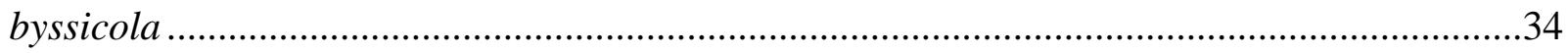

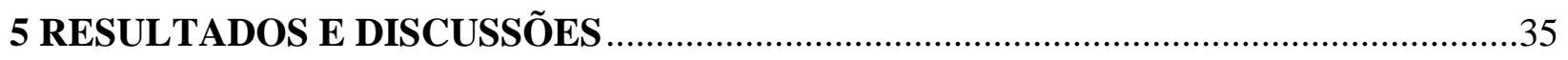

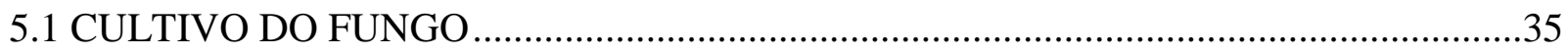

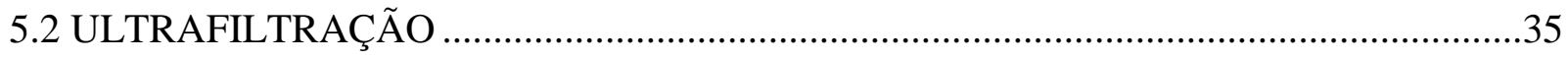

5.3 PURIFICAÇÃO PARCIAL DE MANANASE POR CROMATOGRAFIA DE TROCA

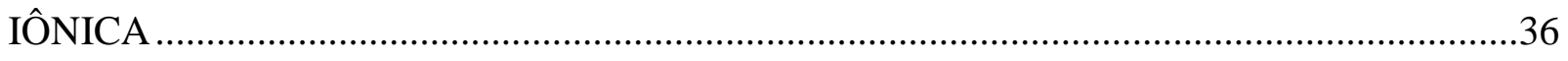

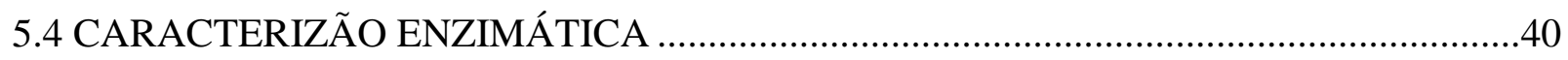




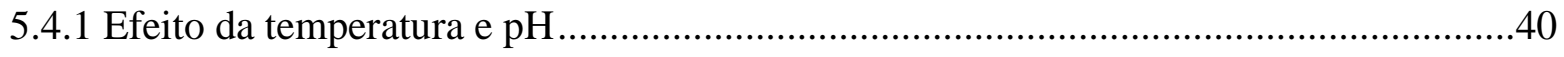

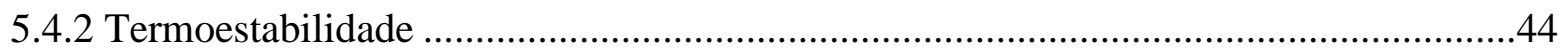

5.4.3 Efeito de íons e EDTA na atividade de mananases ...................................................47

5.4.4 Efeito de compostos fenólicos na atividade de mananases .....................................49

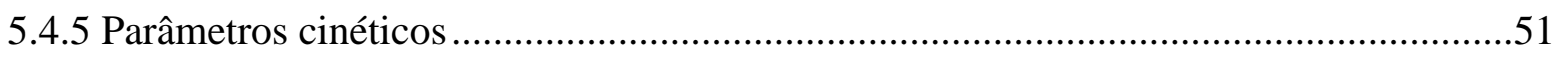

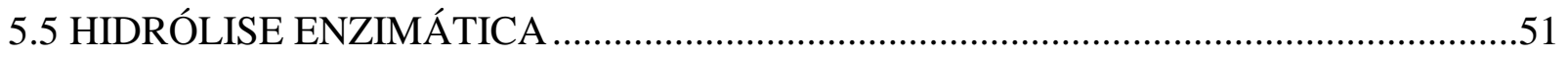

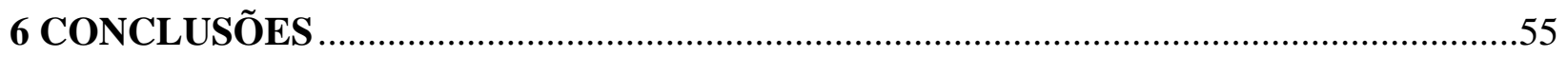

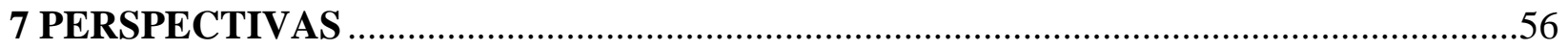

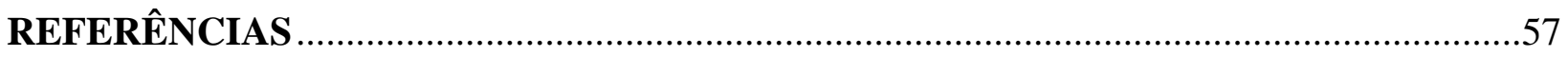




\section{LISTA DE FIGURAS}

Figura 1. Configuração da parede celular vegetal ................................................................

Figura 2. Ilustração esquemática da estrutura da celulose ..................................................4

Figura 3. Estrutura de diferentes formas de mananas ....................................................6

Figura 4. Ilustração esquemática dos principais polissacarídeos pécticos................................8

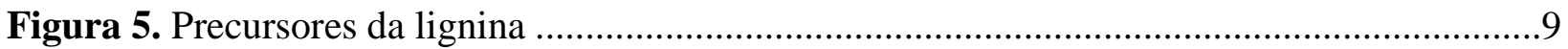

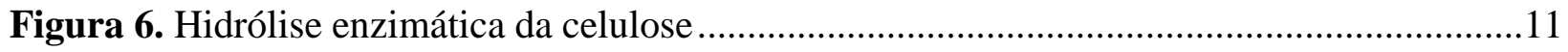

Figura 7. Representação esquemática do celulossoma .....................................................12

Figura 8. Hidrólise enzimática da manana.................................................................. 13

Figura 9. Mecanismo de hidrólise por retenção.................................................................14

Figura 10. Degradação enzimática da pectina por pectinases ..............................................18

Figura 11. Microscopia confocal por fluorescência mostrando a remoção de goma guar por

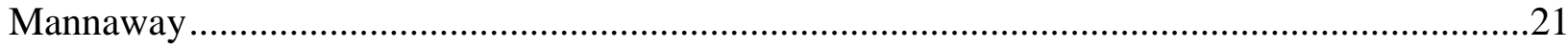

Figura 12. Esquema da purificação parcial e caracterização de $\beta$-mananases de $C$. byssicola

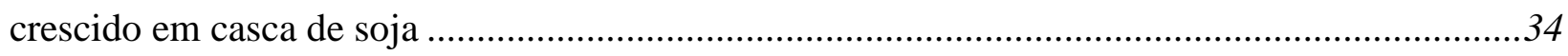

Figura 13. Perfil cromatográfico do EBC em cromatografia de troca aniônica (DEAE Sepharose

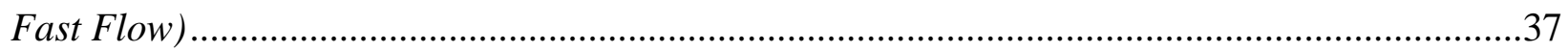

Figura 14. Perfil cromatográfico das frações ManDEAE em cromatografia de troca aniônica $Q$ Sepharose Fast Flow.

Figura 15. SDS-PAGE e Zimograma das frações cromatográficas: DEAE Sepharose Fast Flow

e $Q$ Sepharose Fast Flow.....

Figura 16. Efeito da temperatura na atividade de mananase ............................................41

Figura 17. Efeito do $\mathrm{pH}$ na atividade de mananase ................................................................42

Figura 18. Determinação da termoestabilidade de mananase do extrato bruto concentrado a 40, 50 e $55^{\circ} \mathrm{C}$ 
Figura 19. Determinação da termoestabilidade de mananase da fração semi-purificada a 40, 50 e $55^{\circ} \mathrm{C}$ .46

Figura 20. Quantificação de açúcares redutores totais por DNS obtidos pela hidrólise da manana $1 \%$ e da casca de soja pelas enzimas do EBC

Figura 21. Identificação de mano-oligossacarídeos produzidos durante a hidrólise da manana $1 \%$ por enzimas presentes no EBC . .54 


\section{LISTA DE TABELAS}

Tabela 1. Composição química da casca de soja ...............................................................25

Tabela 2. Resultados obtidos a partir da ultrafiltração do extrato bruto de C. bysicola ...............36

Tabela 3. $\mathrm{pH}$ e temperatura ótima de mananase descrita para diferentes microrganismos ..........43

Tabela 4. Efeito de íons e EDTA na atividade de mananase ...............................................48

Tabela 5. Efeito de íons e EDTA na atividade de mananases de diversos microrganismos........49

Tabela 6. Efeito de compostos fenólicos na atividade de mananase ........................................51 


\section{LISTA DE ABREVIATURAS}

AAs: atividades auxiliares

CBH: celobiohidrolases

CBM: módulo de ligação ao carboidrato

CDH: celobiose desidrogenase

CM: farelo de copra

GG: goma guar

KG: goma de konjac

LiP: lignina peroxidase

LBG: goma de alfarroba

Man-DEAE: fração reunida da cromatografia utilizando a coluna DEAE Sepharose Fast Flow

Man-QFF: fração reunida da cromatografia utilizando a coluna HiTrap Q Sepharose Fast Flow

MnP: manganês peroxidases

DNS: ácido 3,5-dinitro-salicílico

EBC: extrato bruto concentrado
EG: endoglicanase

EDTA: ácido etilenodiamino tetra-acético

GH: glicosídeo hidrolase

HPLC: cromatografia líquida de alta performance

LPMO: monooxigenases líticas de polissacarídeos

PS: parede secundária

PG: poligalacturonases

PKM: farelo de amêndoa de palma

PMG: polimetilgalacturonase

PMGL: polimetilgalacturonato liase

SDS-PAGE: dodecil sulfato de sódio eletroforese em gel de poliacrilamida

UI: Unidade Internacional 


\section{RESUMO}

As mananases microbianas são principalmente enzimas extracelulares, cuja produção é grandemente influenciada por fatores nutricionais e fisioquímicos, como fonte de nitrogênio, carbono, $\mathrm{pH}$, temperatura, agitação e concentração de oxigênio dissolvido. Dada a propriedade de atuar em uma ampla faixa de $\mathrm{pH}$ e temperatura, as mananases microbianas apresentam uma variedade de aplicações, podendo ser empregadas na produção de etanol de segunda geração, indústrias têxteis, como também no melhoramento do valor nutricional de alguns alimentos. Neste trabalho, o fungo filamentoso Clonostachys byssicola foi utilizado para produção de mananases tendo a casca de soja como fonte de carbono. C. byssicola, foi cultivado em meio submerso contendo casca de soja $1 \%$ por sete dias. O extrato bruto, concentrado por ultrafiltração (EBC) com membrana de retenção de $30 \mathrm{kDa}$, apresentou atividade de mananase de 4,18 $\mathrm{UI} / \mathrm{mL}$. As amostras de mananases presentes no EBC foram semi-purificadas por dois tipos de cromatografia de troca aniônica: DEAE Sepharose Fast Flow (DEAE) e Q Sepharose Fast Flow (QFF). O EBC e a fração semi-purificada (ManQFF) apresentaram temperaturas com maior atividade à 55 e $45^{\circ} \mathrm{C}$, respectivamente. Ambas as amostras enzimáticas foram mais ativas em $\mathrm{pH}$ 5,0. As amostras enzimáticas do EBC e ManQFF apresentaram termoestabilidade a $40^{\circ} \mathrm{C}$ por um período de 192 horas e $50 \mathrm{~min}$, respectivamente. $\mathrm{O}$ íon $\mathrm{Co}^{2+}$ aumentou as atividades de mananases do $\mathrm{EBC}(15 \%) \mathrm{e}$ ManQFF (35\%) quando incubado em uma concentração final de $10 \mathrm{mM}$. Contudo, os compostos fenólicos inibiram a atividade de mananase. A atividade de mananase do EBC apresentou um $\mathrm{K}_{\mathrm{M}}$ aparente de $12,73 \pm 1,97 \mathrm{mg} / \mathrm{mL}$ e $\mathrm{V}_{\text {máx }}$ de 7,65 \pm 0,52 UI/mL, enquanto a presente na fração semi-purificada exibiu $\mathrm{K}_{\mathrm{M}}$ de $8,53 \pm 0,31 \mathrm{mg} / \mathrm{mL}$ e $\mathrm{V}_{\text {máx }}$ de 0,255 $\pm 0,0033 \mathrm{UI} / \mathrm{Ml}$. A análise da eletroforese e zimografia, mostrou que $C$. byssicola produz proteoformas de mananases com massas moleculares variando de 36,6 a $53 \mathrm{kDa}$. Ademais, os ensaios de hidrólise enzimática da manana $1 \%$ e da casca de soja $1 \%$ com amostras do EBC, mostraram a produção de grandes quantidades de manooligossacarídeos, cujos principais produtos liberados foram manose e manobiose.

Palavras chave: mananase, casca de soja, Clonostachys byssicola 


\begin{abstract}
Microbial mannanases are mainly extracellular enzymes whose production is greatly influenced by nutritional and physicochemical factors such as nitrogen and carbon sources, $\mathrm{pH}$, temperature, agitation and dissolved oxygen concentration. Given the property of acting in a wide range of $\mathrm{pH}$ and temperature, the microbial manannases present a variety of applications, being able to be used in the production of second generation ethanol, textile industries, as well in improving the nutritional value of some foods. In this work, the filamentous fungus Clonostachys byssicola was used to produce mannanases having the soybean hull $1 \%$ as carbon source $C$. byssicola, was cultivated in submerged medium containing soybean hull for seven days. The crude extract was concentrated by ultrafiltration $(\mathrm{EBC})$ membrane with retention of $30 \mathrm{kDa}$ and presented mananase activity of $4.18 \mathrm{IU} / \mathrm{mL}$. The mannanase samples present in the EBC were semipurified by two types of anion exchange chromatography: DEAE Sepharose Fast Flow (DEAE) and Q Sepharose Fast Flow (QFF). Both, EBC and semi-purified fraction (ManQFF) were more active at 55 and $45^{\circ} \mathrm{C}$, respectively. Both enzymatic samples were also more active at $\mathrm{pH}$ 5.0. Regarding their thermostability, EBC and ManQFF enzymatic samples showed half-lives of 192 hours and $50 \mathrm{~min}$ at $40^{\circ} \mathrm{C}$, respectively. The $\mathrm{Co}^{2+}$ ion increased mannanase activities of EBC (15\%) and ManQFF (35\%) when incubated at a final concentration of $10 \mathrm{mM}$. However, phenolic compounds inhibited the activity of mannanase. EBC mannanase activity had an apparent $\mathrm{K}_{\mathrm{M}}$ of $12.73 \pm 1.97 \mathrm{mg} / \mathrm{mL}$ and $\mathrm{V}_{\max }$ of $7.65 \pm 0.52 \mathrm{IU} / \mathrm{mL}$, whereas the semi-purified fraction exhibited $\mathrm{K}_{\mathrm{M}}$ of $8.53 \pm$ $0.31 \mathrm{mg} / \mathrm{mL}$ and $\mathrm{V}_{\max }$ of $0.255 \pm 0.0033 \mathrm{IU} / \mathrm{mL}$. Electrophoresis and zymogram studies showed that $C$. byssicola produces proteoforms of mannanases with molecular mass varying from 36.6 to $53 \mathrm{kDa}$. In addition, enzymatic hydrolysis experiments of mannan $1 \%$ and soybean hulls $1 \%$ with EBC samples showed the production of large quantities of mannooligosaccharides, mannobiose and mannose.
\end{abstract}

Keywords: mannanase, soybean hull, Clonostachys byssicola 


\section{INTRODUÇÃO}

A biomassa lignocelulósica, um dos maiores componentes estruturais presentes em plantas, representa grande parte da matéria orgânica renovável sendo composta principalmente de lignina, celulose e hemicelulose. Devido as suas propriedades químicas, esse substrato apresenta grande importância biotecnológica (HOWARD, et al., 2003; MALHERBE \& CLOETE 2002). A conversão de materiais lignocelulósicos em produtos com valores agregados, tais como substratos para fermentação, compostos químicos e biocombustíveis é uma estratégia de desenvolvimento sustentável (FERNANDO, et al., 2006; RAGAUSKAS, et al., 2006). A otimização do uso da biomassa, de modo que se tenham cadeias de valores similares àquelas dos derivados do petróleo, é o principal objetivo da biorrefinaria. Biorrefinaria é definida como uma instalação que integra processos de conversão de biomassa em biocombustíveis, insumos químicos, materiais, alimentos e energia (EMBRAPA AGROENERGIA, 2015). Os principais setores responsáveis por fornecerem matéria prima renovável para biorrefinaria são agriculturas, silviculturas e indústrias (CHERUBINI, 2010).

Os resíduos agroindustriais são fontes de carbono utilizadas para o crescimento de diversos tipos de microrganismos, dentre eles, os fungos filamentosos estão entre os principais microrganismos que degradam lignocelulose em ambientes naturais (ÁLVAREZ; REYES-SOSA; DÍEZ, 2015). Um dos fatores que dificultam a degradação desses resíduos é a presença dos polissacarídeos que compõe a parede celular das plantas, também conhecidos como holocelulose vegetal, e a lignina. Juntos, eles são responsáveis por aumentar a recalcitrância da parede celular vegetal, dificultando sua degradação, como também a intrusão de microrganismos (ABRAMSON; SHOSEYOV; SHANI, 2009; SIQUEIRA e FERREIRA FILHO, 2010).

A complexidade e heterogeneidade da parede celular das plantas requer a ação sinérgica de glicosil hidrolases produzidas por microrganismos. A quebra da estrutura holocelulósica é realizada por um conjunto de enzimas, incluindo celulases, hemicelulases e pectinases (SIQUEIRA et al., 2009). Uma forma de facilitar a degradação da estrutura lignocelulósica é a inclusão de etapas de pré-tratamento que facilitam a remoção de lignina, tornando a celulose e hemicelulose mais acessíveis às enzimas hidrolíticas (MOREIRA, 2013). Dentre os métodos de pré-tratamento, são descritos os métodos físicos (moagem), químicos (ácido diluído), térmicos (tratamento a vapor) e biológicos (fungos que degradam a madeira) (KRISTENSEN, 2009). Durante o pré- 
tratamento, parte da hemicelulose é removida devido à sua proximidade com a celulose, entretanto, grande parte desse polissacarídeo permanece na fração sólida do material, podendo ser utilizado como substrato para indução enzimática (MOREIRA, 2013).

A maioria das enzimas industriais são hidrolíticas, sendo utilizadas para degradação de substâncias naturais. Depois das proteases, as carboidrases representam o segundo maior grupo de enzimas utilizadas em indústrias têxteis e de detergente (KIRK; BORCHERT; FUGLSAND, 2002). Como as celulases e xilanases, as enzimas que degradam manana (mananase) possuem aplicações em diversos processos biotecnológicos, incluindo indústrias de papel, têxtil, café, alimentos, produção de etanol de segunda geração (RODRÍGUEZ et al., 2012).

\subsection{COMPOSIÇÃO DA PAREDE CELULAR VEGETAL}

A parede celular da planta é uma fonte de lignocelulose, cuja estrutura é representada principalmente pela interação físico-química de celulose, hemicelulose e lignina (ANDREAUS; FERREIRA FILHO; BON, 2008). Descrita como uma estrutura dinâmica, a parede celular é composta por três camadas (fig. 1). A primeira camada a ser formada é a lamela média, onde sua formação começa nas etapas finais da divisão celular. A lamela média é responsável por unir as paredes celulares vegetais adjacentes, consistindo principalmente de substâncias pécticas e algumas proteínas. Os componentes pécticos formam géis hidrofílicos que cimentam uma célula à outra produzindo tecidos (SIQUEIRA e FERREIRA FILHO, 2010; VANNUCE e REZENDE, 2003).

A parede celular primária é uma estrutura altamente hidratada. Depositada durante o crescimento celular ela contém poucas microfibrilas de celulose que estão embebidas em uma matriz gelatinosa composta por pectina, hemicelulose, glicoproteínas, extensinas e expansinas. A parede primária apresenta algumas funções como suporte mecânico, estrutural e proteção contra patógenos (REITER, 2002; SIQUEIRA e FERREIRA FILHO, 2010).

A parede celular secundária é formada depois que a célula atinge forma e tamanhos definidos. Quando se considera a mesma célula, geralmente, a parede secundária é mais espessa e menos hidratada que a parede primária apresentando três camadas sucessivas de celulose (S1, S2 e S3). A quantidade de celulose presente na parede secundária é maior que a primária, no entanto a presença de hemicelulose é menos abundante. A lignina começa a ser formada no final do espessamento da parede, 
normalmente na lamela média, fortalecendo os tecidos e aumentando a rigidez da parede celular (KRISTENSEN, 2009; KUBICEK, 2012; SIQUEIRA e FERREIRA FILHO, 2010).

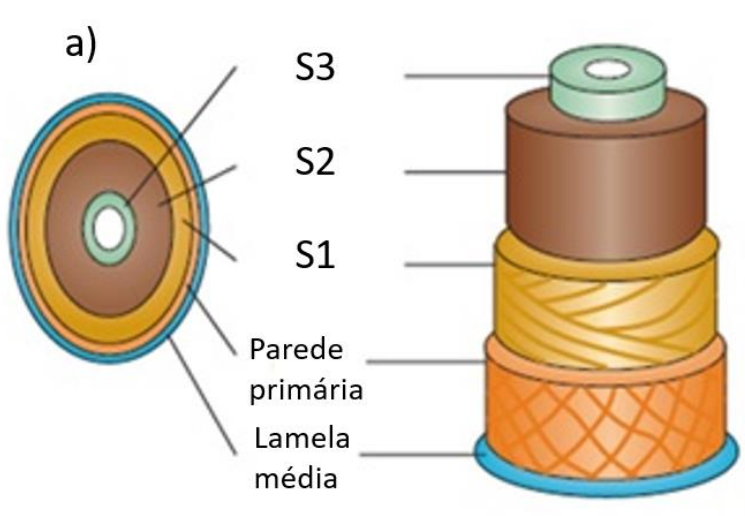

b)

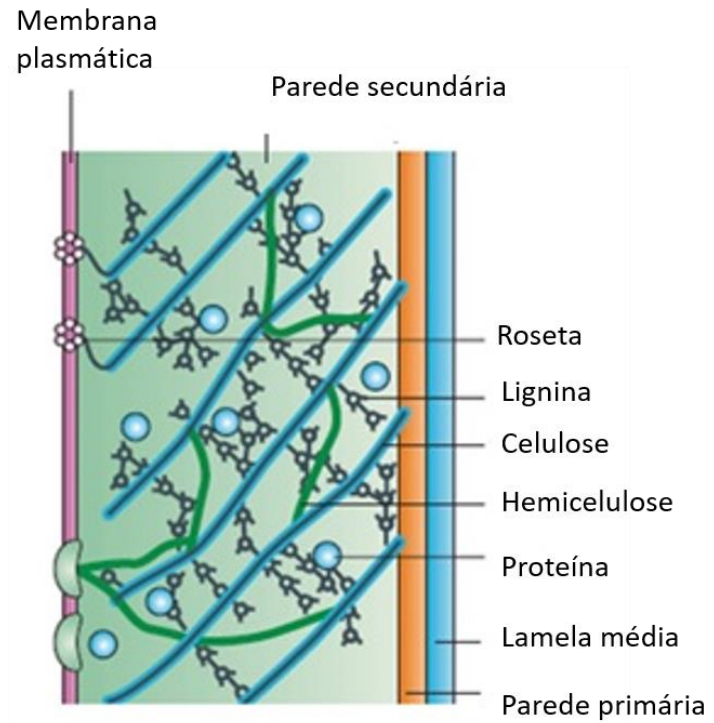

Figura 1:Configuração da parede celular vegetal. a) Camadas da Parede celular vegetal; b) Parede celular secundária representada por S1, S2 e S3. Extraído de Sticklen (2008).

\subsubsection{Celulose}

A celulose é o polissacarídeo mais abundante da natureza, compondo cerca de 45\% do peso seco da madeira (ARO; PAKULA; PENTTILÃ, 2005; PÉREZ, et al., 2002). Pode ser encontrada em plantas e alguns microrganismos, como bactérias. Umas das principais funções da celulose é atuar como polímero estrutural (SAMIR; ALLOIN; DUFRESNE, 2005). Na natureza, a celulose está disponível na sua forma quase pura, como polpas de algodão, ou como fibras embebidas em uma matriz de biopolímeros estruturais, principalmente hemicelulose e lignina (LYND, et al., 2002). Constituída por unidades de glicose unidas por ligações glicosídicas do tipo $\beta-(1,4)$ os polissacarídeos celulósicos apresentam unidades repetitivas, denominadas celobiose, e formam um homopolímero de cadeira linear que está associado com outras cadeias de celulose através ligações de hidrogênio e forças de van der Waals (fig.2). Juntas, as cadeias de celulose formam microfibrilas que podem assumir duas diferentes formas, a forma cristalina, uma estrutura insolúvel, e a forma amorfa, no qual a celulose não tem um arranjo definido, 
nessa condição a celulose está sucessível a maiores ataques enzimáticos (KUBICEK, 2012; VILLARREAL et. al., 2012).

A forma cristalina da celulose é devido às forças atrativas que existem entre as moléculas formando microfibrilas altamente ordenadas, sendo resistentes a tração, solvatação, ao alongamento, e consequentemente, são insolúveis a maioria dos solventes (AZEVEDO, 2011). O grau de polimerização (DP) das moléculas de celulose, pode variar de acordo com o tipo de celulose utilizada, valores de DP 10.000 em celulose de madeira e 15.000 em celulose de algodão, são parâmetros que contribuem para o estudo de suas propriedades físico-químicas. (SAMIR; ALLOIN; DUFRESNE, 2005).

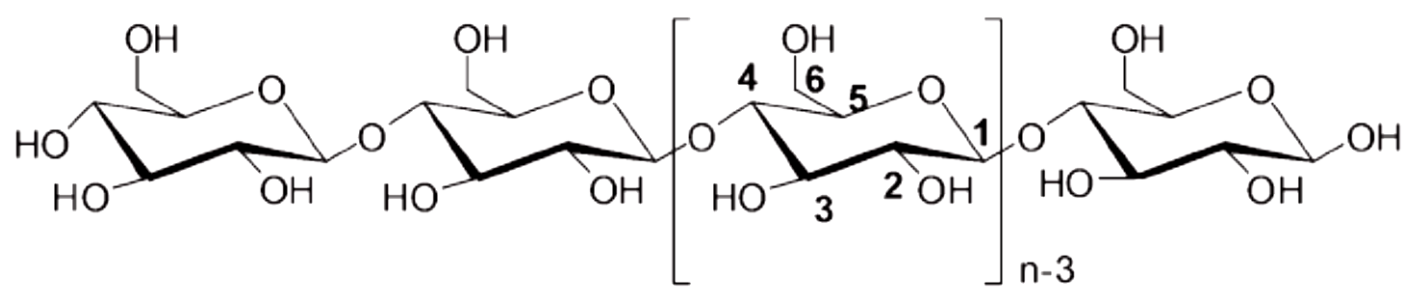

Figura 2: Ilustração esquemática da estrutura da celulose (HUANG e FU, 2013).

\subsubsection{Hemicelulose}

Hemiceluloses são o segundo polissacarídeos mais abundantes na natureza, representando certa de $20-30 \%$ do peso seco da madeira. Seus polímeros heterogêneos podem apresentar cadeias lineares ou ramificadas de açúcares como a xilose, galactose, manose, glicose e arabinose. Encontrados em estreita associação com a celulose e a lignina nas paredes celulares das plantas, as classes de hemiceluloses são nomeadas de acordo com as unidades principais de açúcares presentes na cadeia principal. Cerca de um terço de todos os componentes presentes em plantas é representado por heteropolímeros hemicelulósicos. A quantidade de hemicelulose encontrada na parede primária é maior do que em paredes secundárias e sua composição nas plantas pode variar em angiospermas e gimnospermas. Em gimnospermas são encontradas principalmente galactoglicomananas e glicomananas, em contrapartida, a presença de arabinoglicoronoxilanas e acetilglicoroxilanas são mais frequentes em angiospermas. Geralmente, hemiceluloses encontradas em angiospermas são moléculas maiores quando comparada com moléculas encontradas em gimnospermas, podendo conter entre 150-200 
resíduos (DHAWAN e KAUR, 2007; MALGAS; DYK; PLETSCHKE, 2015; MOREIRA e FERREIRA FILHO, 2008).

As mananas, distribuídas como parte das frações hemicelulósicas em gimnospermas, angiospermas, sementes e plantas de leguminosas, são polissacarídeos constituídos de resíduos de hexoses lineares ou ramificados. As mananas são classificadas em quatro subfamílias: Mananas lineares, glicomananas, galactomananas e galactoglicomananas (fig.3). As cadeias principais de manose são unidas por ligações do tipo $\beta$ - $(1,4)$ podendo apresentar uma combinação de resíduos de manose e outros polissacarídeos, como também, ramificações de resíduos de galactose (MOREIRA e FERREIRA FILHO, 2008). As mananas apresentam diversas funções nas plantas, tais como estrutural, estando em estreita associação com a celulose, armazenamento, em endospermas de semente e vacúolos de tecidos vegetais, e como molécula sinalizadora para o desenvolvimento e crescimento de algumas plantas (LIEPMAN et al., 2007; MOREIRA E FERREIRA FILHO, 2008).

Mananas lineares são polissacarídeos compostos de resíduos de manose, contendo menos que 5\% de galactose. Alguns desses polissacarídeos apresentam propriedades imunofarmacológica e terapêutica, podendo ser encontrados em grãos de café e endospermas de Palmae (MOREIRA E FERREIRA FILHO, 2008).

Galactomananas, consistem de um esqueleto carbônico formados por resíduos de manose, apresentando cadeias laterais de galactose com ligações do tipo $\alpha-(1,6)$. Devido a presença de galactose, são polissacarídeos solúveis em água, podendo ser derivados de gomas guar, tara e alfarroba. Esses polímeros podem ser utilizados como espessantes e estabilizantes de muitos produtos alimentares (PARVATHY, et al., 2005; SHOBHA, et al., 2005). Galactomananas apresentam mais que 5\% de resíduos de galactose, sua distribuição pode variar em diferentes tipos de plantas, sendo encontrada principalmente em sementes das famílias de leguminosas. Quando localizadas em endospermas de sementes, galactomananas apresentam funções fisiológicas, sendo responsáveis por reterem água, impedindo o secamento de sementes e a desnaturação de proteínas essenciais para a germinação (MOREIRA E FERREIRA FILHO, 2008).

Glicomananas compreendem resíduos de manose e glicose que estão interligados, aleatoriamente, apresentando ligações do tipo $\beta-(1,4)$, com uma proporção de 3:1 (manose/glicose). São polissacarídeos que podem atuar como preventivos de doenças crônicas e como agentes de controle de peso. Elas estão presentes em pequenas 
quantidades em frações hemicelulósicas de angiospermas e representam certa de 3-5\% do material celular total (MOREIRA E FERREIRA FILHO, 2008).

Galactoglicomananas são heteropolissacarídeos que apresentam uma cadeia principal linear contendo resíduos de manose e glicose, com ligações do tipo $\beta$ - $(1,4)$, e pontos de ramificações de $\alpha$-galactoses. A galactose, pode se ligar tanto a manose quanto aos resíduos de glicose. Sua solubilidade em água é devido a presença de substituintes laterais de galactose (MOREIRA E FERREIRA FILHO, 2008; WILLFÖR, 2003).

A)

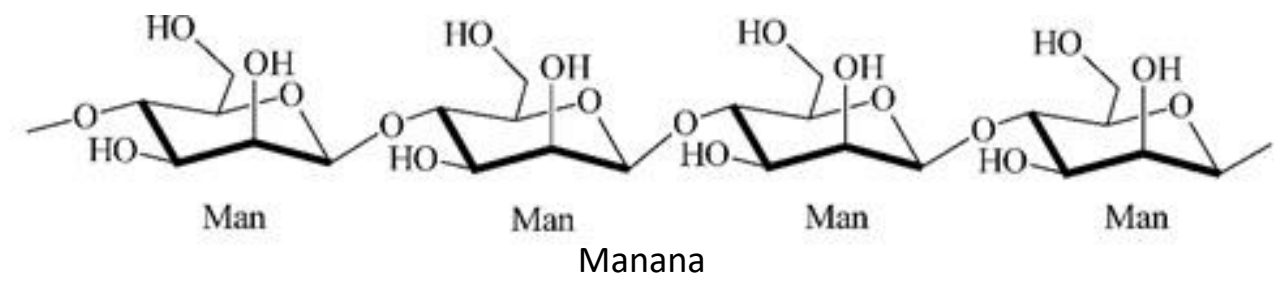

B)

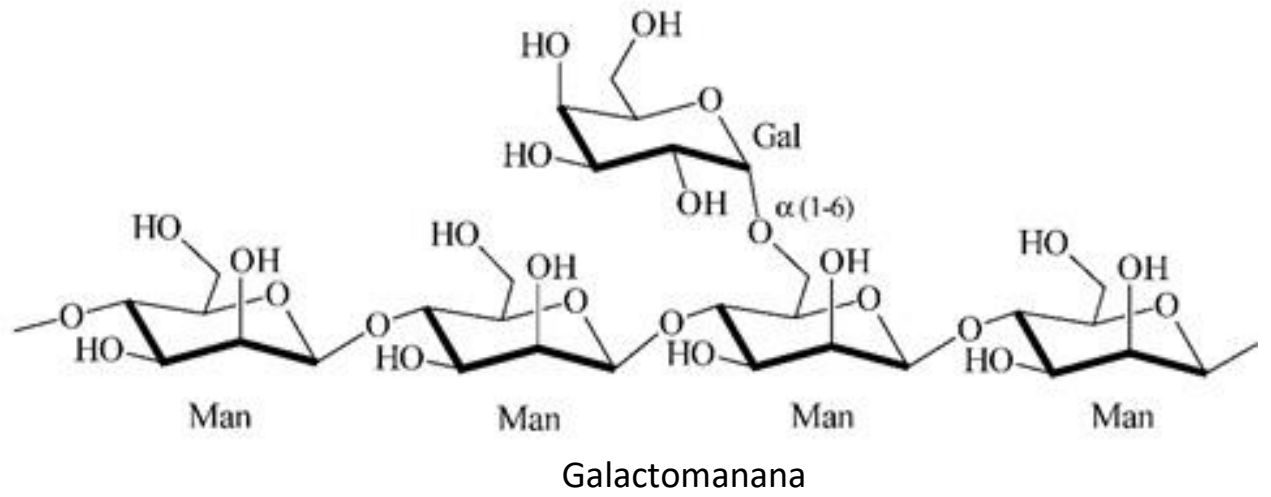

C)

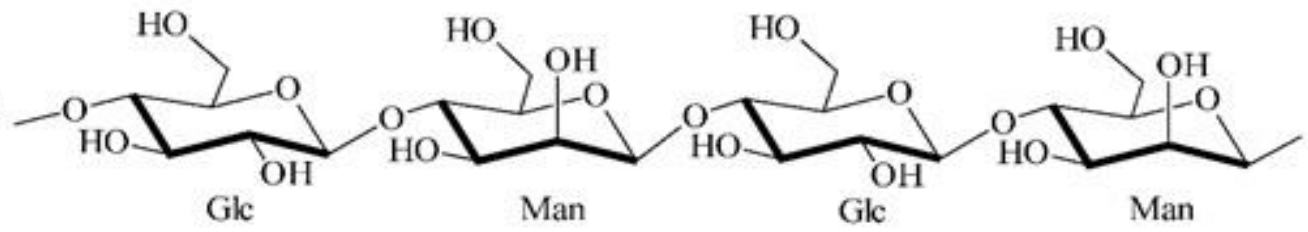

D)

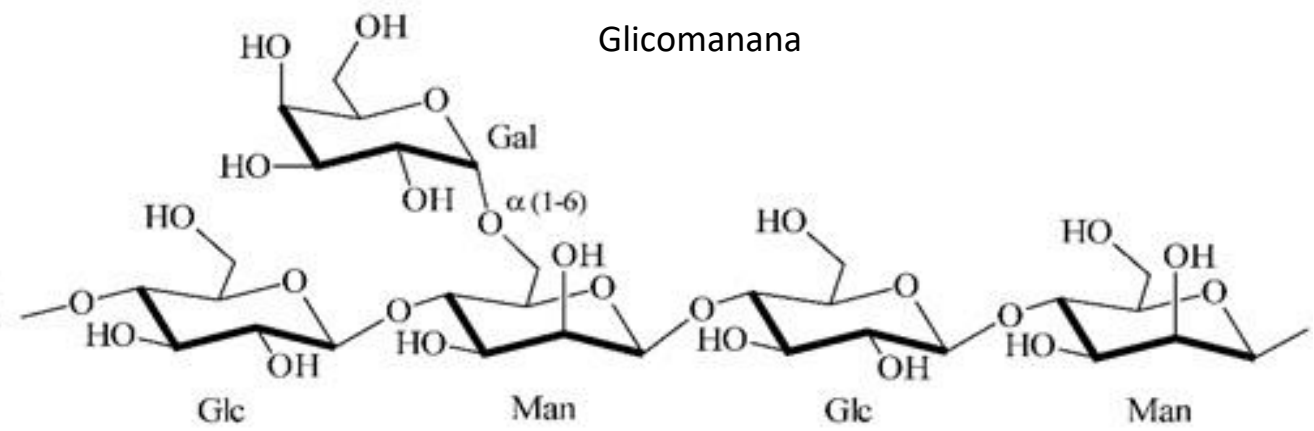

Galactoglicomanana

Figura 3. Estrutura das diferentes formas de mananas. A) Manana linear; B) Galactomanana; C) Glicomanana; D) Galactoglicomanana. (DHAWAN e KAUR 2007). 


\subsubsection{Pectina}

Os polissacarídeos pécticos estão entre os mais complexos da parede celular sendo considerados polissacarídeos estruturais (JARAMILLO, 2014; PALIN e GEITMAN, 2012). As substâncias pécticas são um complexo coloidal de polissacarídeos ácidos, formados por resíduos de ácido galacturônico unidos por ligações do tipo $\alpha-(1,4)$, sendo encontrados principalmente na lamela média. No geral, o termo pectina, designa ácidos pectíneos solúveis em água, contendo diferentes grupos de metil éster, e um grau de neutralização capaz de formar géis com açúcares e ácidos (UENOJO e PASTORE, 2007). As pectinas apresentam regiões ramificadas e não ramificadas, podendo ser classificadas em três famílias (fig. 4): homogalacturonana, ramnogalacturonana I e ramnogalacturonana II. Homogalacturonanas são compostas por cadeias lineares de resíduos de ácido galacturônico, representando os polissacarídeos pécticos mais abundantes da parede celular e correspondendo cerca de 60-65\% do total das pectinas. Ramnogalacturonanas I, são formadas por resíduos alternados de ácido galacturônico e ramnose. A estrutura desse polissacarídeo, apresenta uma composição de açúcares altamente heterogêneos, podendo ser lineares ou ramificados. Ramnogalacturonana II, contém um domínio complexo de pectina constituído por onze tipos diferentes de açúcares, compondo 10\% da pectina (CAFFALL e MOHNEN, 2009; JARAMILLO, 2014; PALIN e GEITMAN, 2012).

As pectinas são substâncias com grande relevância nas indústrias alimentares, sendo utilizadas para a produção de géis, como gelatinas. As diversidades nas estruturas de pectinas geram diferentes propriedades gelificantes. A tendência para a formação de géis se dá pela distribuição dos grupos hidrofílicos e hidrofóbicos, responsáveis pela solubilidade da pectina. Além do mais, o grau de esterificação também pode influenciar as propriedades químicas (MAATSCH, et al., 2016). A utilização de pectinas em indústrias farmacêuticas, tem mostrado o grande potencial desses polissacarídeos na influência de níveis favoráveis de colesterol no sangue. Nesse caso, um consumo de $6 \mathrm{~g}$ por dia de pectina é necessário para um significante efeito na redução do colesterol. Ademais, pectinas atuam como substâncias profiláticas naturais, contra o envenenamento por cátions tóxicos. Sendo efetiva na remoção de chumbo e mercúrio do sistema respiratório e gastrointestinal (SRIAMORNSAK, 2003).

Maiores proporções dos polissacarídeos pécticos são encontradas em lamelas médias de alguns tipos de plantas, entretanto, para o uso comercial as pectinas são 
extraídas de frutas cítricas, bagaço de maçã, como também subprodutos da fabricação de sucos. Outras fontes alternativas incluem resíduos de beterraba, provenientes da fabricação de açúcar, resíduos de girassóis, sementes utilizadas para produção de óleo comestível e resíduos de manga (SRIAMORNSAK, 2003).

Ramnogalacturonana II

Homogalacturonana

Ramnogalacturonana I

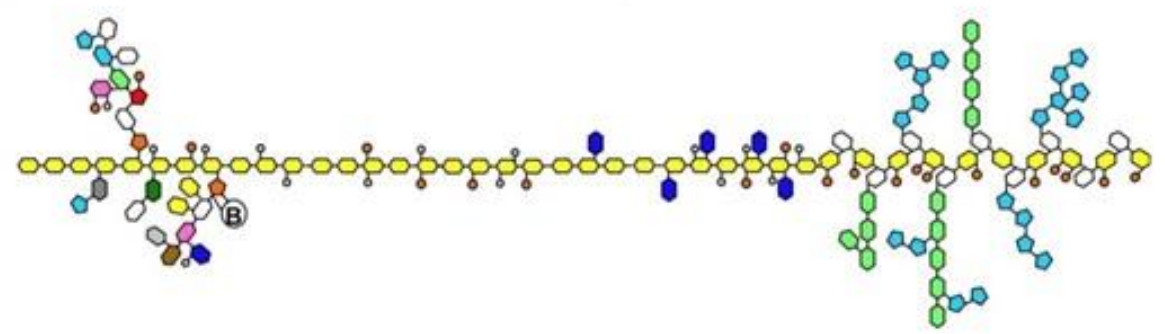

Figura 4. Ilustração esquemática dos principais polissacarídeos pécticos. (HARHOLT; SUTTANGKAKUL e SCHELLER, 2010).

\subsubsection{Lignina}

A lignina compreende um complexo polifenólico que são depositados predominantemente durante o espessamento da parede celular secundária, tornando a parede celular rígida e impermeável. Sua biossíntese pode ocorrer de forma natural, evento programado pelas células, ou de forma induzível, devido a condições de estresses e perturbações nas moléculas da parede celular (VANHOLME, et al., 2010). Os principais constituintes da lignina (fig. 5) são denominados monolignóis, álcool coniferílico, álcool sinapílico e álcool p- coumarílico (ACKER et al., 2013). Em angiospermas a composição de lignina se dá principalmente por unidades de guaiacil e siringil, no entanto, gimnospermas são constituídas principalmente por unidades de guaiacil, apresentando uma menor quantidade de p-hidroxifenil (BOERJAN; RALPH; BAUCHER, 2003).

Sintetizada por uma grande quantidade de plantas e algumas espécies de algas, a lignina constitui cerca de $15-40 \%$ da massa seca de plantas. Tem como função fornecer suporte estrutural, aumentando a recalcitrância da parede, uma vez que ela está associada a celulose e a hemicelulose, sendo assim resistente a ataques biológicos. (ABRAMSON; SHOSEYOV; SHANI, 2010; GHAFFAR e FAN, 2013).

As ligninas apresentam diversos tipos de aplicações, podendo ser utilizadas industrialmente como agentes dispersantes em tintas, pesticidas, inseticidas, auxiliando 
na redução de água, resultando em um produto menos permeável. Atua como agente emulsificante e como estabilizador de emulsões, como também, tem sido utilizada como aditivos de adesivos, podendo ser incorporada em adesivos poliméricos, como resinas fórmicas e poli-acrilamidas (HERNÁNDEZ, 2007).

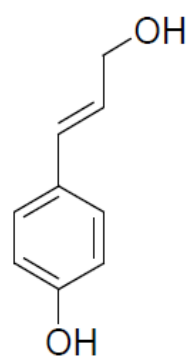

(a)

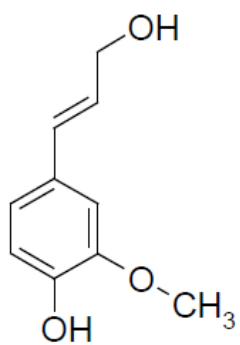

(b)<smiles>COc1cc(/C=C/CO)cc(OC)c1O</smiles>

(c)

Figura 5: Precursores da lignina. a) Álcool p- coumarílico; b) Álcool coniferílico; c) Álcool sinapílico. (DOHERTY; MOUSAVIOUN; FELLOWS, 2011).

\subsection{ENZIMAS QUE DEGRADAM A BIOMASSA LIGNOCELULÓSICA}

\subsubsection{Celulases}

As celulases podem ser encontradas em uma diversidade de microrganismos. Em bactérias as celulases estão presentes como estruturas agregadas que atacam as células, denominadas celulossomas, em contrapartida, as celulases de fungos apresentam uma arquitetura simples, contendo um domínio catalítico e um módulo de ligação ao carboidrato (CBM). O mecanismo de hidrólise enzimática da celulose ocorre pela ação sinérgica de três classes de enzimas: endoglicanases, celobiohidrolases ou exoglicanases e as $\beta$-glicosidases. (JUTURU e WU, 2014).

As endoglicanases, clivam ligações internas da celulose, preferencialmente as regiões amorfas, liberando oligossacarídeos de diferentes tamanhos e consequentemente, expondo as extremidades das cadeias glicosídicas para que as celobiohidrolases, possam atuar (HORN et al., 2012). Celobiohidrolases, degradam regiões terminais redutoras 
(celobiohidrolases I) e não redutoras (Celobiohidrolases II) liberando como produto final a celobiose, contudo, em casos extremos pode haver a liberação de glicose (MOREIRA; MILANEZI; FERREIRA FILHO, 2011). Por fim, a celobiose liberada é clivada em resíduos de glicose pelas $\beta$-glicosidases, que servem como uma fonte de carbono metabolizável por fungos (ARO; PAKULA; PENTTILÃ, 2005).

A atuação de outros tipos de enzimas responsáveis por despolimerizar a celulose tem sido identificada por diversos pesquisadores (fig. 6). As celulases oxidativas são responsáveis por degradar a celulose por meio de reações de radical livre. Algumas enzimas acessórias como oxidases líticas atuam juntamente com endoglicanases liberando oligômeros com extremidades redutoras das cadeias glicosídicas (JUTURU e WU, 2014). Essas enzimas pertencem a classe de monooxigenases líticas de polissacarídeos (LPMO), anteriormente classificadas como GH61 e CMB33 no banco de dados do CAZy (http://www.cazy.org). As LPMOs degradam a estrutura cristalina da celulose por um mecanismo oxidativo, tornando o substrato acessível a outros tipos de enzimas. As LPMOs, previamente descritas como GH61 e CMB33, apresentam similaridades estruturais, como um agrupamento amino N-terminal e duas histidinas que podem se ligar a íons metálicos. Essas enzimas foram reclassificadas como atividades auxiliares (AAs) das famílias AA9 e AA10, respectivamente (HEMSWORTH, et al., 2014; HORN, et al., 2012).

As enzimas pertencentes a família AA9, representada quase exclusivamente por fungos que degradam a madeira, catalisam a hidrólise oxidativa da celulose na presença de um doador externo de elétron, como o ácido gálico. São enzimas que apresentam atividade dependente de cobre oxidando, principalmente, o carbono $\mathrm{C} 1$ da estrutura do anel da glicose, podendo também oxidar os carbonos C4 e C6. Essas diferenças, poderiam ser explicadas pela não especificidade de algumas enzimas, como também por diferenças entre as sequências de AA9. Outros estudos sobre AA9 mostram que além do ácido gálico, as enzimas pertencentes a essa família podem utilizar diferentes tipos de doadores de elétron, como ácido ascórbico, glutationa reduzida, e as celobioses desidrogenases. Ademais em substratos que contém lignina, a lignina atua como doadora de elétrons. (HORN, et al., 2012).

As enzimas da AA10, comumente encontradas em bactérias e vírus, são monooxigenases dependentes de cobre que utilizam oxigênio molecular e doadores de elétron externos. São enzimas capazes de degradar oxidativamente estruturas cristalinas 
de quitina e celulose. Essas enzimas, aumentam a acessibilidade do substrato para enzimas hidrolíticas, e assim, atuam sinergicamente. As enzimas pertencentes as famílias AA10 são estruturalmente similares as AA9, apresentam superfícies planas que permitem a ligação do substrato (LEVASSEUR, et al., 2013).

A celobiose desidrogenase $(\mathrm{CDH})$ é uma enzima extracelular produzida por vários fungos que degradam a madeira, responsável por oxidar celodextrinas, manodextrinas e lactose. Essas enzimas pertencem a subfamília AA3_1, são hemoflavoenzimas extracelulares produzidas sob condições de culturas que contém celulose, como fonte de carbono, por fungos. As CDHs são responsáveis por oxidarem o carbono na posição $\mathrm{C} 1$ de uma molécula de celobiose, o hemiacetal é convertido em uma lactona que hidrolisa espontaneamente um ácido carboxílico (HENRIKSSON; JOHANSSON; PETTERSSON, 2000; LEVASSEUR, 2013).

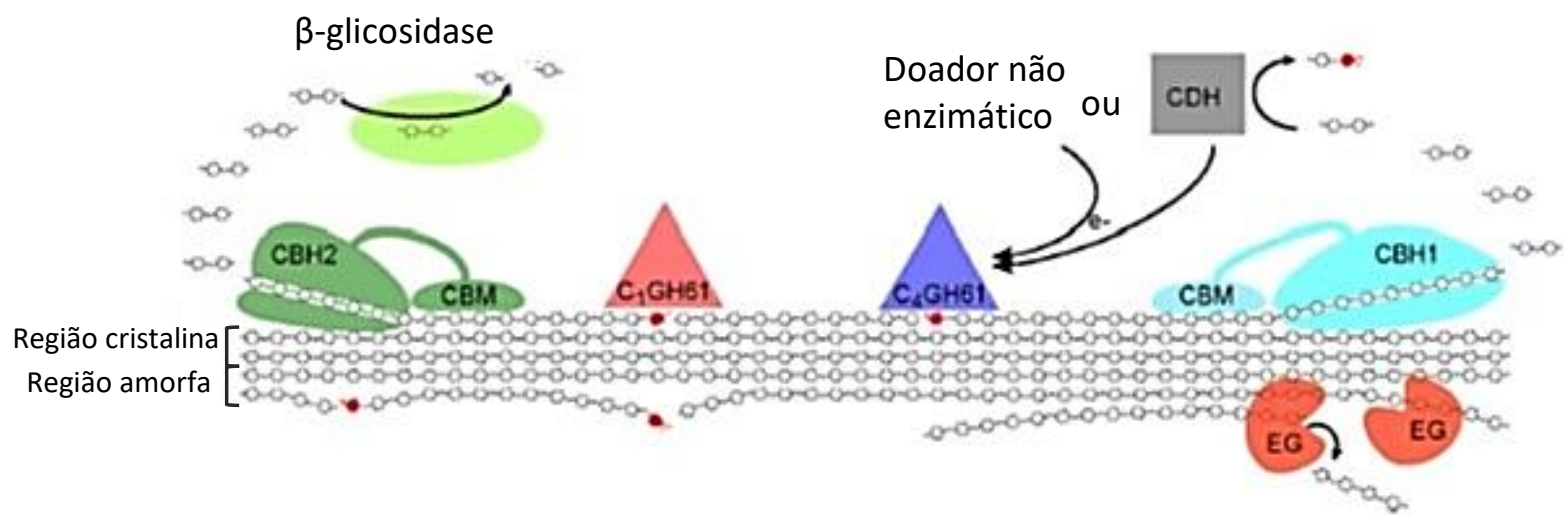

Figura 6. Hidrólise enzimática da celulose. Abreviações: EG, endoglicanases; $\mathrm{CBH}$, celobiohidrolases; $\mathrm{CDH}$, celobiose desidrogenase; CBM, modulo de ligação ao carboidrato; GH61, glicosil hidrolases da família 61. (HORN, et al., 2012).

As celulases de diversos microrganismos apresentam em sua estrutura um domínio catalítico, região que ocorre a catálise enzimática, e um CBM. Inicialmente os CBMs foram classificados como domínio de ligação a celulose (CBD), baseados na descoberta inicial de vários módulos que se ligavam a celulose. Contudo, esses módulos foram encontrados em outros tipos de enzimas, necessitando assim de uma reclassificação desses polipeptídeos. Geralmente os CBMs são encontrados em famílias de glicosil hidrolases, que contém enzimas que degradam polissacarídeos solúveis (SHOSEYOV; SHANI; LEVY, 2006; VÁRNAI; SIIKA-AHO; VIIKARI, 2013). 
As celobiohidrolases e as endoglicanases apresentam em sua estrutura um módulo catalítico e um CBM. O CBM tem como função permitir o contato do domínio catalítico com o substrato para assegurar uma orientação correta, aumentar a concentração de enzimas no substrato e romper a estrutura cristalina do substrato. O domínio catalítico é conectado ao CBM por sequências de ligação, e a falta do CBM pode acarretar em uma redução da atividade hidrolítica do módulo catalítico (ARANTES e SADDLER, 2010).

A degradação da celulose por bactérias é realizada por meio de complexos multienzimáticos, denominados celulossomas (fig. 7). Os celulossomas estão ligados a superfície da célula bacteriana e consistem de enzimas descritas na literatura, como exoglicanases, endoglicanases, xilanases, mananase, liquenase, esterase feruloil, e algumas proteínas que apresentam funções estruturais. Celulossomas apresentam uma estrutura bastante ordenada, cada subunidade do celulossoma apresenta um domínio não catalítico que interage com uma proteína estrutural, contendo um CBM e nove elementos repetitivos, denominados coesinas. Alguns microrganismos apresentam outro domínio designado domínio de peptídeo repetido 2 (DPR2), que está relacionado com a ligação da proteína estrutural à parede celular da bactéria (XIMENES e FELIX, 2003).

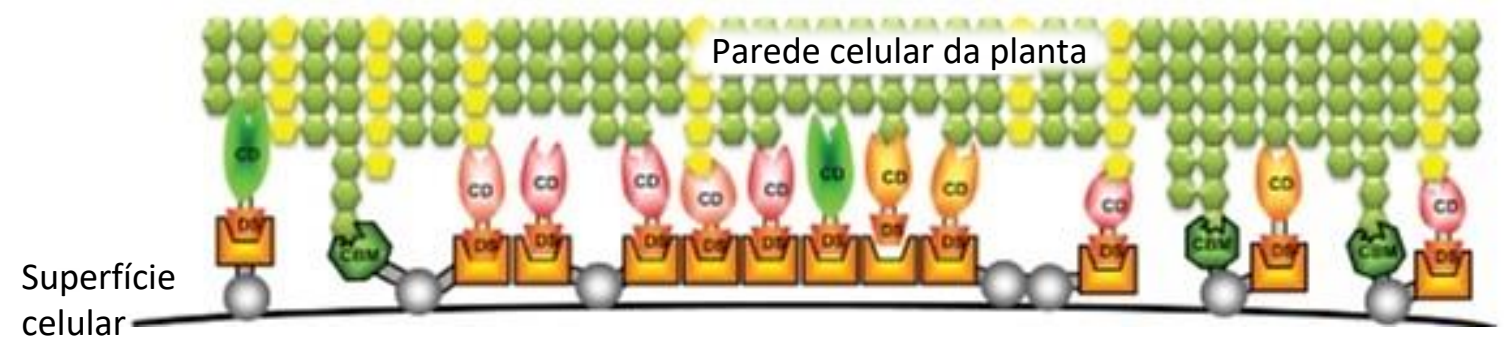

Figura 7. Representação esquemática do celulossoma. Abreviações: CBM, modulo de ligação ao carboidrato; CD, domínio catalítico; DS, domínio “dockerin” ou domínio de peptídeo repetido (TAMARU, et al., 2010).

\subsubsection{Hemicelulases}

A degradação da estrutura hemicelulósica de mananas envolve a ação sinérgica de enzimas que clivam a cadeia principal de polissacarídeos e removem substituintes laterais (fig. 8). Sinergismo ocorre quando a atividade exibida por misturas de sistemas enzimáticos é maior do que a soma das atividades dessas enzimas quando avaliadas individualmente. Com relação as enzimas mananolíticas, dois tipos de sinergismo são observados, o homosinergismo e heterosinergismo. Homosinergismo é definido como a 
cooperatividade entre duas enzimas que degradam a cadeia principal (por exemplo, $\beta$ mananases e $\beta$-manosidases) ou entre duas enzimas que removem os substituintes laterais (como as $\alpha$-galactosidases e acetil-manana esterase). Por outro lado, heterosinergismo é a interação sinérgica entre enzimas que degradam a cadeia principal e cadeias laterais (MOREIRA e FERREIRA FILHO, 2008; ZHANG e LYND, 2004).

As enzimas que degradam a manana fazem parte de um grande arsenal de glicosil hidrolases produzidas por fungos e bactérias que degradam a madeira. Essas enzimas são classificadas com base na similaridade de suas sequências podendo ser agrupadas em famílias 5 e 26 de glicosil hidrolases, compostas de endoglicanases e mananases. Membros da família 5 são representados por enzimas que degradam manana, podendo ser encontradas em bactérias e diversos microrganismos eucariotos, apresentando enzimas com estruturas em forma de barril. Em contrapartida, a família 26 é representada, quase exclusivamente, por enzimas produzidas por bactérias (MOREIRA e FERREIRA FILHO, 2008; VAN ZYL, et al., 2010).

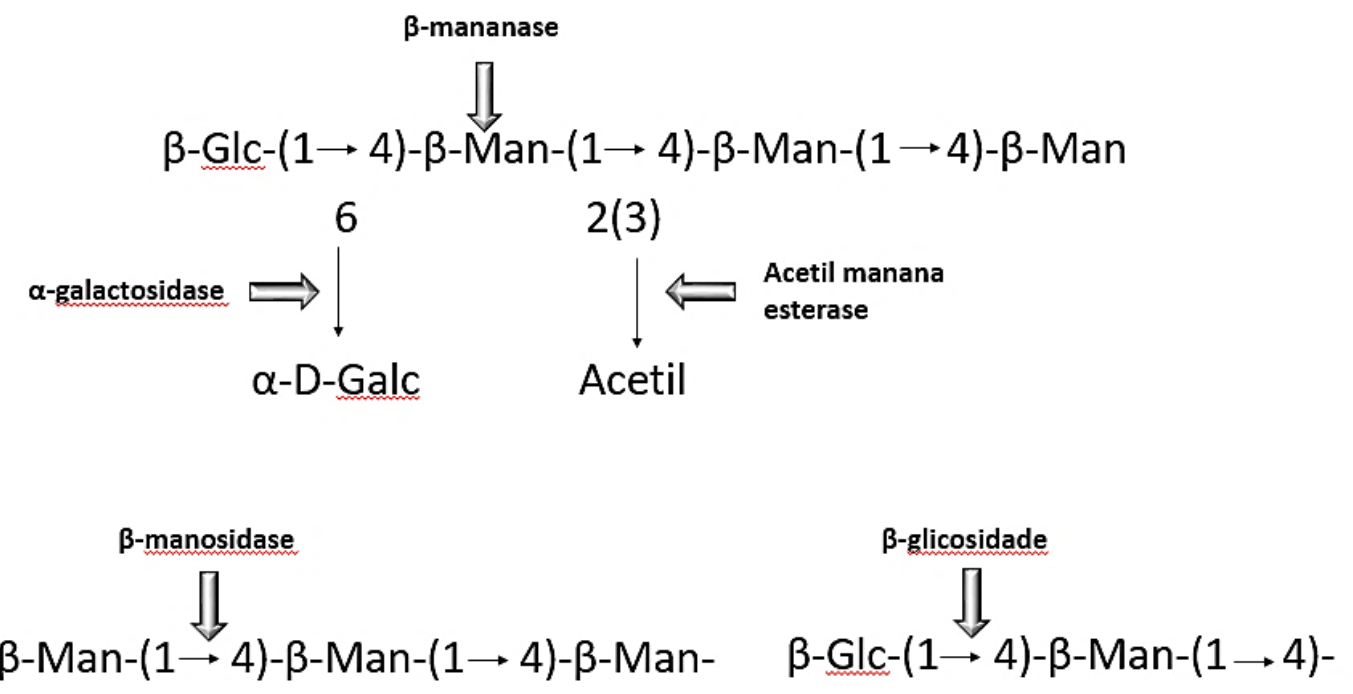

Figura 8. Hidrólise enzimática de manana (CHAUHAN et al., 2012).

A maioria das enzimas envolvidas na hidrólise das mananas lineares são $\beta$ mananases e $\beta$-manosidases. As $\beta$-mananases são enzimas responsáveis por degradarem regiões internas do esqueleto carbônico da manana, liberando mano-oligômeros e produzindo novas cadeias com extremidades não redutoras. Essa classe de enzimas pertencem as famílias 5, 26 e 113 de GHs. Tem sido relatado que os principais produtos liberados durante a hidrólise da manana são manobiose e manotriose. $\beta$-mananases 
presentes nas famílias 5 e 113 podem, além da hidrólise, realizarem reações de transglicosilação (MALGAS; DYK; PLETSCHKE, 2015; VAN ZYL, et al., 2010).

As $\beta$-manosidases são enzimas responsáveis por catalisarem a hidrólise de extremidades não redutoras de oligômeros de manana, gerando como produto manose, podendo ser encontradas em famílias 1, 2 e 5 de GH (MALGAS; DYK; PLETSCHKE, 2015; VAN ZYL, et al., 2010).

A remoção da glicose de glicomananas é realizada por $\beta$-glicosidases, uma exoenzima, pertencente as famílias 1 e 3 de GHs. Suas enzimas clivam extremidades não redutoras de oligossacarídeos. A maioria das $\beta$-glicosidases são inibidas por resíduos de glicose e não são capazes de clivarem longas cadeias contendo ligações do tipo $\beta-(1,4)$. Enzimas adicionais como $\alpha$-galactosidases e acetil manana esterases são responsáveis por clivarem cadeias laterais de galactose e liberarem grupos acetil de galactoglicomananas, respectivamente (MALGAS; DYK; PLETSCHKE, 2015; VAN ZYL, et al., 2010).

As enzimas que degradam manana apresentam modo de ação por retenção da configuração do carbono anomérico (fig. 9). Esse mecanismo ocorre por deslocamento duplo. A hidrólise das ligações glicosídicas ocorre por meio de catálise ácido/básica envolvendo dois ácidos carboxílicos presentes nas cadeias laterais de aspartato e glutamato posicionadas no sítio ativo. A priori, um grupo carboxílico atua como ácido, catalisando a protonação do oxigênio glicosídico, em contrapartida, o outro grupo carboxílico age como nucleófilo, formando um intermediário glicosil-enzima. Admite-se que o estado de transição apresente caráter dissociativo, no qual a quebra da ligação glicosídico ocorre antes do ataque nucleófilo. No segundo momento da reação, o grupo carboxílico que agiu como ácido, passa a atuar como base, removendo um próton de uma molécula de água, e simultaneamente a molécula de água hidrolisa o complexo glicosilenzima. No final da reação, a enzima passa a ter as mesmas configurações (BRÁS; FERNANDES; RAMOS, 2009; CHAUHAN, et al., 2012). 


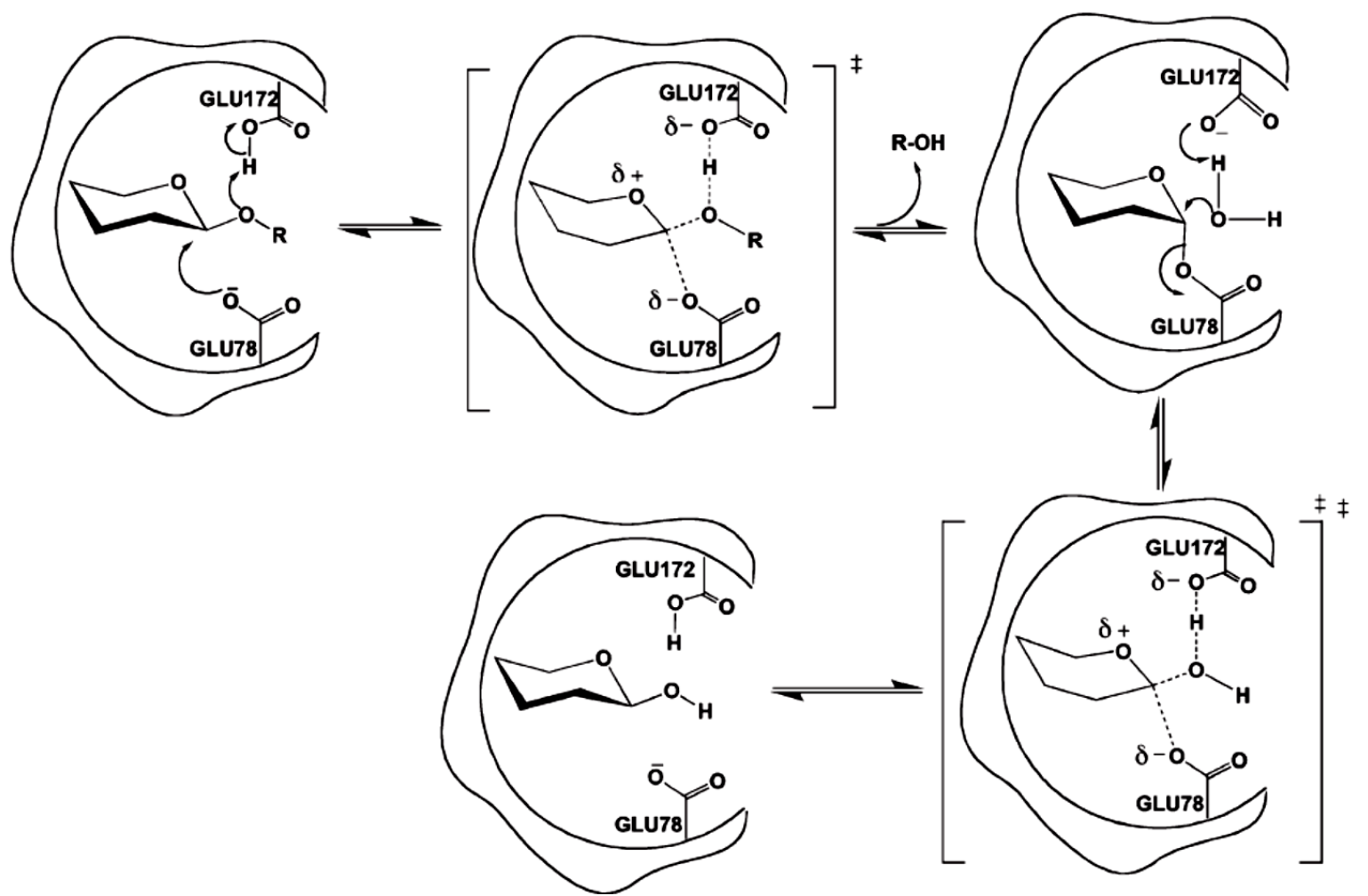

Figura 9. Mecanismo de hidrólise por retenção (MHLONGO, et al., 2014).

Mananases podem apresentar CBM em suas estruturas. Ainda que seus módulos catalíticos sejam similares, a presença e a localização de CBM podem variar entre as enzimas. Atualmente, 81 famílias de CBM têm sido relatadas e o número da sua classificação está disponível no banco de dados $C A Z y$. Mananases de fungos aeróbios como Clonostachys rosea e Aspergillus bisporus pertencem a família 1 de CBM. Essa família é composta quase exclusivamente por organismos eucariotos, seus módulos contêm aproximadamente 40 resíduos. Entretanto, mananases bacterianas das famílias 5 e 26 de GH exibem uma estrutura mais complexa. Cellulomonas fimi produz $\beta$-mananases que possui CBM da família 23 e um módulo putativo homólogo à camada $\mathrm{S}$ (SLH). Uma comparação das estruturas de diferentes mananases revela que CBMs tem sido predito para enzimas pertencentes às famílias 5 e 26 de GHs. Entretanto, apenas poucos estudos têm confirmado a presença de CBMs experimentalmente (DHAWAN e KAUR, 2007). Dentre as características encontradas em mananases que contêm CBM podem ser citadas o aumento da atividade enzimática, uma vez que esses módulos auxiliam o domínio catalítica a se ligar as cadeias de polissacarídeos, como também o aumento da termoestabilidade enzimática, uma vez que os CBMs podem fornecer proteção ao domínio catalítico (LU, et al., 2013; SRIVASTAVA, et al., 2016). 
Microrganismos são fontes ricas de uma variedade de enzimas. Enzimas que degradam mananas tem sido produzidas por uma diversidade de espécies de fungos e bactérias. As mananases são enzimas induzíveis podendo ser produzidas por fermentação no estado sólido ou líquido, utilizando diferentes substratos. A realização da fermentação no estado sólido tem algumas vantagens, incluindo menor investimento, uma vez que não é necessária a utilização de equipamentos sofisticados, agitação branda, além do mais, o crescimento do microrganismo ocorre em condições mais próximas às dos habitats naturais. Contudo, a maioria dos trabalhos tem utilizado culturas líquidas, devido a uma maior facilidade de controlar parâmetros para o crescimento de microrganismos, tais como pH, temperatura e aeração (MOREIRA e FERREIRA FILHO, 2008).

A produção de mananases por cepas requer a utilização de substratos ricos em galactomananas, como a goma de alfarroba, pó de konjac e farelo de trigo. Além da fonte de carbono, diferentes fontes de nitrogênio utilizada no meio influenciam a produção de mananases. Geralmente o nitrogênio orgânico, como a peptona e o extrato de levedura é preferido por diferentes espécies de Bacillus, enquanto o extrato de carne tem sido utilizado para Clostridium tertium. Devido a pequena quantidade de enzimas produzidas naturalmente por microrganismos, a superexpressão de enzimas é necessária para a utilização dessas ferramentas em aplicações comerciais. E uma forma de obter grandes quantidades de enzimas é por meio de expressão heteróloga (CHAUHAN et al., 2012; DHAWAN e KAUR, 2007).

\subsubsection{Pectinases}

As pectinases representam $25 \%$ nas vendas globais de enzimas alimentares, podendo ser utilizadas em vários processos industriais. A utilização de pectinases na clarificação e extração de sucos de frutas tem sido proposta e estabelecida por diversas pesquisas. Recentemente, as pectinases têm recebido grande destaque em outras aplicações biotecnológicas, como processamento têxtil, pré-tratamento de águas industriais, extração de óleos vegetais e fabricação de papel (JAYANI; SAXENA; GUPTA, 2005; TEWARI; TEWARI; HOONDAL, 2005). As enzimas pectinolíticas são produzidas em diferentes combinações por plantas e microrganismos. (UENOJO e PASTORE, 2007). A maioria das enzimas pectinolíticas pertencem à família 28 de GH, e são caracterizadas por exibirem estruturas compostas de hélices com folhas $\beta$. Essas enzimas podem ser divididas em grupos de acordo com o modo de clivagem dos 
polímeros de pectina. (BRINK e VRIES, 2011). Para a degradação da pectina são necessárias duas classes de enzimas: GH e polissacarídeos liases (BRINK e VRIES, 2011).

As pectinases são compostas por três diferentes tipos de enzimas (fig. 10): pectinas esterases, despolimerizantes (incluem as enzimas hidrolíticas e liases) e as protopectinases. A pectina esterase, também conhecida como pectina metil hidrolase, catalisa a hidrólise de grupos metil éster da pectina, liberando metanol e formando ácido péctico. A enzima atua, preferencialmente, em grupos ésteres metilados de unidades de galacturonato próximo a uma unidade não esterificada. As enzimas despolimerizantes podem hidrolisar ligações glicosídicas e realizarem reações de transeliminação. As enzimas que atuam na hidrólise de ligações glicosídicas são: polimetilgalacturonase (PMG), enzimas que rompem ligações glicosídicas do tipo $\alpha$ - $(1,4)$ de pectinas; e poligalacturonases $(\mathrm{PG})$, responsáveis por catalisarem ligações do tipo $\alpha-(1,4)$ de pectinas ácidas. As liases, rompem ligações do tipo $\alpha-(1,4)$ por transeliminação, que resulta em um galacturonideo com uma ligação insaturada entre o carbono C4 e C5 em extremidades não redutoras. São compostas por dois grupos de enzimas: polimetilgalacturonato liase (PMGL), enzimas que clivam cadeias de pectinas por transeliminação; e poligalacturonato liase (PGL), que degradam as ligações glicosídicas de pectinas ácidas por transeliminação. O terceiro grupo de enzimas é representado por protopectinases, enzimas responsáveis por solubilizarem protopectina, podendo clivar regiões internas e externas da cadeia de polissacarídeos (KASHYAP et al., 2001; UENOJO e PASTORE, 2007). 

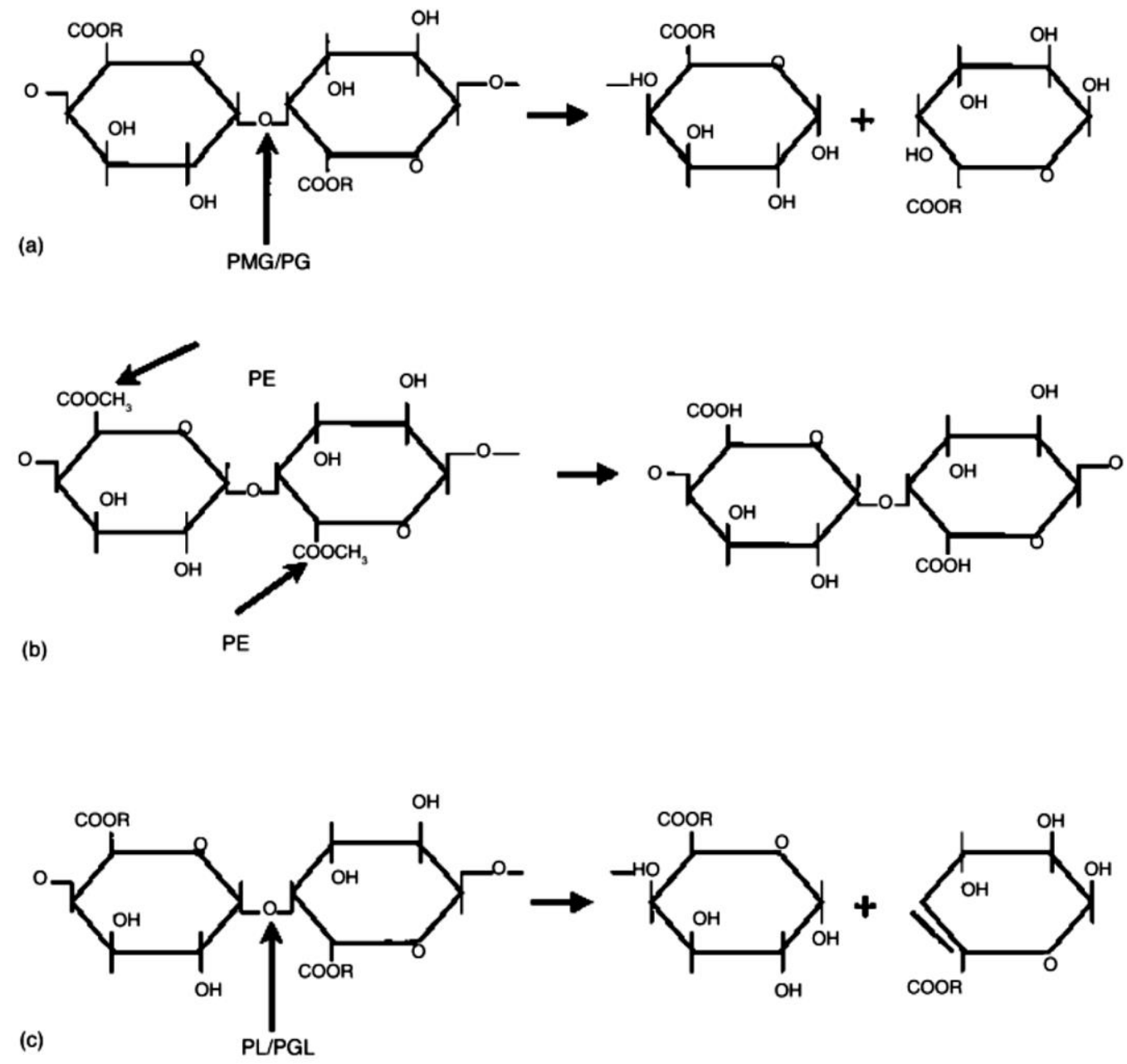

Figura 10. Degradação enzimática da pectina por pectinases. Abreviações: PMG, polimetilgalacturonase; PG, poligalacturonases; PE, pectina esterase; PL, pectina liase; PGL, poligalacturonato liase. A) $\mathrm{R}=\mathrm{H}$ para PG e $\mathrm{CH}_{3}$ para PMG; b) remoção de ésteres por PE; c) $\mathrm{R}=\mathrm{H}$ para PGL e $\mathrm{CH}_{3}$ para PL. (JAYANI; SAXENA; GUPTA, 2005).

\subsubsection{Ligninases}

$\mathrm{Na}$ natureza, os basidiomicetos são os principais fungos responsáveis por degradarem a lignina de madeiras. Os basidiomicetos são classificados em fungos causadores da podridão branca e marrom, baseado principalmente em aspectos macroscópicos (MARTÍNEZ et al., 2005). Os fungos causadores da podridão marrom são responsáveis por desconstruírem polímeros de celulose e hemicelulose, mantendo a lignina preservada numa forma levemente modificada, a degradação completa apenas dos polissacarídeos que compõe da madeira é justificada pela preferência do fungo por esses compostos. O resultado final dessa decomposição é a obtenção de uma madeira de consistência quebradiça, podendo se desintegrar a pó, e com uma coloração marrom, devido a presença de lignina. Os fungos causadores da podridão branca degradam a 
lignina e os demais polissacarídeos encontrados na madeira. Após a degradação dos componentes lignocelulósicos a madeira adquire uma coloração branca. Esses fungos são responsáveis por decomporem a madeira por meio de duas formas: deslignificação seletiva e simultânea. Na deslignificação seletiva, a lignina é degradada deixando intacto os demais polissacarídeos. Essa degradação pode ser visualizada macroscopicamente com o surgimento de zonas claras, regiões que contém apenas celulose. Em contrapartida, na deslignificação simultânea, tem-se a quebra de moléculas de lignina, celulose e hemicelulose de forma concomitante (SCHWARZE; ENGELS; MATTHECK, 2000).

As enzimas que degradam a lignina são oxidativas. Devido à natureza e o tamanho das moléculas de lignina as enzimas responsáveis pelo ataque inicial devem ser extracelulares e não específicas, atuando através de mediadores não proteicos, diferente da hidrólise de celulose e hemicelulose. As principais enzimas que degradam a lignina são: manganês peroxidase (MnP), lignina peroxidase (LiP) e lacases (ARO; PAKULA; PENTTILÃ, 2005; TUOMELA, et al., 2000).

A MnP é uma enzima que possui um grupo heme, sendo dependente de $\mathrm{H}_{2} \mathrm{O}_{2}$ para sua atividade. $\mathrm{O} \mathrm{Mn}^{2+}$ atua como agente oxidante do radical superóxido formando $\mathrm{Mn}^{3+}$. Os íons $\mathrm{Mn}^{3+}$ gerados atuam como mediadores de transferência de carga difusíveis permitindo a oxidação de vários substratos fenólicos. A LiP é capaz degradar compostos não fenólicos da lignina. Na presença de $\mathrm{H}_{2} \mathrm{O}_{2}$, a LiP pode remover elétrons de estruturas não fenólicas, originado radicais cátion, podendo degradar por clivagem oxidativa ligações de carbono da cadeia principal. Contudo, as lacases contêm cobre em seu sítio não necessitando de $\mathrm{H}_{2} \mathrm{O}_{2}$ para a sua atividade catalítica. As lacases podem oxidar grupos fenólicos, atuando como enzimas iniciais da clivagem de cadeias laterais e anéis aromáticos de regiões fenólicas da lignina (CONCEIÇÃO, 2010; LOPES, 2016).

\subsection{APLICAÇÃO INDUSTRIAL DAS MANANASES}

As mananases microbianas são principalmente enzimas extracelulares, cuja produção é grandemente influenciada por fatores nutricionais e fisioquímicos, tais como tempo de incubação, temperatura, $\mathrm{pH}$, fontes de nitrogênio e carbono, agitação e concentração de oxigênio. Dada a propriedade de atuar em uma ampla faixa de pH e temperatura, as mananases microbianas apresentam uma variedade de aplicações podendo ser utilizadas em indústrias de papéis, na hidrólise do extrato de café, na 
indústria de detergente e no melhoramento do valor nutricional de alimentos (CHAUHAN, et al., 2012; DHAWAN e KAUR, 2007).

\subsubsection{Redução da viscosidade de extratos de café}

Diferentes tipos de mananases são utilizadas para reduzir a viscosidade de extratos de cafés. Devido à grande quantidade de polissacarídeos de mananas presentes nos extratos de café, estes apresentam alta viscosidade, afetando negativamente o processamento do café instantâneo. O processamento do café é composto por várias etapas. Após a colheita do café maduro, os grãos de café são submetidos a um aquecimento controlado, etapa de torra. Posteriormente o café torrado é granulado e inserido dentro de colunas percoladoras. A adição de água e o aumento da temperatura são capazes de extraírem o café solúvel. Após a extração inicia-se o processo de concentração, que consiste na remoção de água e, por fim, o extrato concentrado pode ser seco por liofilização ou aspersão. A adição de enzimas no extrato líquido do café, resulta na hidrólise de galactomananas, e inibe a formação de géis durante a concentração do café instantâneo (DHAWAN e KAUR, 2007; MORALES, 2014).

\subsubsection{Indústria de papel}

Para obtenção de papel, produto constituído basicamente por fibras de celulose, é necessário reduzir a madeira em pequenos fragmentos e transformá-los em polpa (MONTEIRO e SILVA, 2009). As mananases são utilizadas no pré-tratamento de polpas kraft removendo porções de manana de forma seletiva sem afetar a celulose (MOREIRA e FERREIRA FILHO, 2008). A extração de lignina das fibras de celulose é um passo essencial para branqueamento das polpas de celulose. Benech e colaboradores (2007) estudaram o potencial da enzima heteróloga (man5D), uma $\beta$-mananase, em hidrolisar polpas kraft de papel, contudo, quando comparado com uma xilanase comercial, seu efeito foi menor. Clarke et al. (2000) mostraram que apesar da mananase não apresentar uma hidrólise tão efetiva, quando colocada em conjunto com uma xilanase a quantidade de açúcares redutores em um único estágio do branqueamento da polpa foi maior. 


\subsubsection{Indústria de detergentes}

Mananases foram introduzidas no mercado de detergente como agentes contra o reaparecimento de manchas durante a lavagem de roupas. A goma guar, composta de manana e galactose, é utilizada como espessante e estabilizante de alguns tipos de alimentos, como também em produtos de cuidados pessoais. Devido ao seu alto peso molecular, a goma guar pode se ligar aos tecidos. Manchas contendo goma guar incolor podem aparecer em diferentes tipos de tecidos. Da mesma forma, partículas provenientes do desgaste do vestuário ou vindo de outra lavagem podem se ligar a goma guar e aparecer como mancha. Sendo assim, mananases são enzimas que podem clivar as ligações do tipo $\beta-1,4$ entre unidades de mano e guar reduzindo o aparecimento de manchas (SCHÄFER et al., 2005). Além do mais, estudos realizados por Schäfer, et al. (2005) mostraram por meio de microscopia confocal por fluorescência a remoção de goma guar por mananases produzidas por Bacillus sp. (Mannaway) (fig. 11).
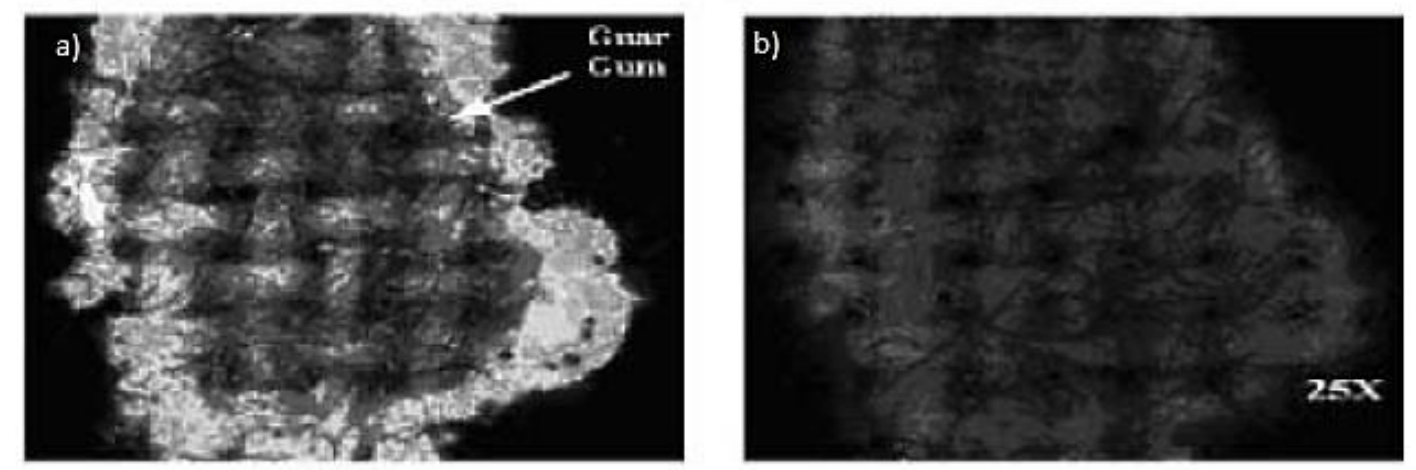

Figura 11. Microscopia confocal por fluorescência mostrando a remoção de goma guar por Mannaway: a) antes da lavagem; b) depois da lavagem (SCHÄFER et al., 2005).

\subsubsection{Mananases como aditivos de rações de animais}

$\beta$-mananas são polissacarídeos encontrados em ingredientes, tais como farelo de soja, farelo de guar e farelo de gergelim. Todos esses farelos apresentam algumas propriedades em comum, como alto conteúdo de fibra, alta viscosidade, baixa palatabilidade, sendo também desprovidos de alguns aminoácidos essenciais. A natureza viscosa da manana é um fator que contribui para a redução da absorção dos nutrientes, pois pode retardar o esvaziamento gástrico prejudicando a mistura do substrato com enzimas digestivas. A incorporação de $\beta$-mananases na dieta de muitos animais pode 
aumentar a hidrólise de $\beta$-mananas, resultando em melhor ingestão dos alimentos, diminuição da viscosidade, como também no aumento da absorção dos nutrientes (CHAUHAN, et al., 2012; MEHRI, et al., 2010).

\subsubsection{Indústria farmacêutica e de alimentos}

A utilização de mano-oligossacarídeos gerados pela hidrólise de substratos que contêm mananas, como gomas guar, alfarroba, Konjac e resíduos lignocelulósicos, tem sido de grande importância para as indústrias farmacêuticas e de alimentos. A estrutura química de mano-oligossacarídeos impede que essas hemiceluloses sejam digeridas em intestinos de mamíferos, devido à ausência de enzimas hidrolíticas, contudo, eles afetam beneficamente e podem ser metabolizadas por colônias de microrganismos, denominadas probióticos. A fermentação de mano-oligossacarídeos é realizada por via glicolítica, sendo responsáveis por estimularem a proliferação de microrganismos desejáveis no cólon do intestino e inibindo do crescimento de patógenos. O local de atuação desses componentes é o intestino grosso, no entanto, eles podem, de algum modo, ter algum efeito sobre os microrganismos do intestino delgado (SAAD, 2006; SRIVASTAVA e KAPOOR, 2016).

\subsubsection{Produção de etanol de segunda geração}

Os materiais lignocelulósicos, como o bagaço de cana, palha de cana e casca de soja são matérias primas para a produção de bioetanol. Sua composição química é um fator chave que afeta a eficiência da produção de biocombustíveis. A utilização dos resíduos agroindustriais e florestais são de grande importância para a produção de combustíveis renováveis, produtos químicos e energia, pois é uma forma de reduzir a quantidade de resíduos gerados evitando a contaminação de solos e rios (NUNES, et al., 2013; SANTOS e GOUVEIA, 2009). Esse processo pode ser dividido em três partes: pré-tratamento, hidrólise e fermentação. A conversão microbiana da hemicelulose em componentes fermentescíveis é um passo crucial para a produção de etanol de segunda geração. Enzimas termoestáveis que degradam manana e outras hemicelulases podem ser utilizadas para degradarem carboidratos presentes na biomassa lignocelulósica, permitindo a produção de açúcares fermentescíveis e posteriormente esses açúcares são 
fermentados por diversos tipos de leveduras (GÍRIO et al., 2010; MOREIRA e FERREIRA FILHO, 2008).

\subsubsection{Extração de óleo de coco}

Mananases podem ser utilizadas na extração enzimática do óleo de coco. A parede celular do coco contém grandes quantidades de hemiceluloses, como mananas e galactomananas. A extração do óleo de coco é realizada, principalmente por extração mecânica, denominada expeller. Nesse tipo de extração, líquidos e sólidos são separados por aplicação de forças de compressão utilizadas por indústrias de alimentos e bebidas. Geralmente, para esse tipo de extração faz se necessária a realização de pré-tratamentos, como a remoção da polpa, redução do tamanho das partículas e aquecimento antes da separação, com intuito de aumentar o rendimento do óleo. Nesse processo, a extração máxima do óleo, é realizada com a adição de solventes, obtendo um produto com suas propriedades naturais alteradas, havendo perda de algumas propriedades químicas. Uma forma de evitar o refinamento excessivo do óleo de coco é por meio da extração enzimática desse componente, resultando no melhoramento da qualidade desse produto, podendo ser obtido o óleo de coco, um óleo aromático, contendo proteínas que podem ser utilizadas como bebida e um isolado de proteínas do coco (CARVALHO, 2011; DHAWAN e KAUR, 2007).

\subsection{O GÊNERO Clonostachys}

Clonostachys foi descrito por Corda entre 1839 e 1840, como espécie única denominada $C$. araucária Corda. Fundamentado em suas descrições e ilustrações $C$. araucária foi identificado como fungo que forma colônias brancas em amostras de solos, contendo conidióforos verticilados. Posteriormente, diversos autores classificaram diferentes fungos como um microrganismo pertencente ao mesmo gênero, nomeado Gliocadium, enfatizando a formação de dois tipos de conídios, verticilados e penicilados. Contudo, pesquisadores perceberam que os dois gêneros poderiam ser distintos por motivos micro morfológicos e por diferenças em seus teleomorfos (SCHROERS, et al., 1999).

O fungo $C$. byssicola comumente encontrado em amostras de solos, em associação com plantas, como também micoparasita, caracteriza-se por apresentar 
estruturas especializadas para formação de conídios, sendo assim denominados conidióforos dimórficos. C. byssicola alimenta-se de matéria orgânica em decomposição (espécie denominada saprófita), apresenta reprodução assexuada, e seu micélio é de coloração alaranjada apresentando conídios hialinos, ovoides e levemente curvados (MOREIRA, 2012; SCHROERS, 2001).

A espécie de $C$. byssicola, pertence à família Bionectriaceae, ordem Hypocreales e filo Ascomycota, seu teleomorfo é conhecido como Bionectria. Dentre as espécies de Clonostachys, C. rosea, tem sido a mais estudada, principalmente pelo seu grande potencial em parasitar hifas de outros fungos e sua utilização como agente de controle biológico contra diversos patógenos (Moreira, 2012).

Assim como $C$. rosea, $C$. byssicola é um fungo que também apresenta atividade antagônica contra alguns fungos, como por exemplo, no biocontrole de Trichoderma spp. em grãos de cacau (KRAUSS et al., 2013), como também na superfície de bananas (ALVINDIA e NATSUAKI, 2008), podendo parasitar hifas de diferentes patógenos.

\subsection{CASCA DE SOJA}

A soja é uma das plantas mais cultivadas no mundo com sua produção alcançando 119,732 milhões de hectares. Por ano, são produzidos 312,362 milhões de toneladas de casca de soja. Depois dos Estados Unidos, o Brasil é o segundo maior produtor mundial de soja, na safra de 2015/2016 a cultura de soja ocupou uma área de 33,177 milhões de hectares, totalizando uma produção de 95 milhões de hectares (EMBRAPA SOJA, 2017). A casca do grão de soja, um subproduto da indústria obtido em uma das primeiras etapas do processamento da semente de soja, constitui por volta de $8 \%$ de todo o grão (MICHEL, et al., 2008). Composta por uma fina camada, denominada tegumento que reveste o grão da casca de soja, é um resíduo de alto valor nutricional, como também para a produção de enzimas hidrolíticas. A composição química da casca de soja pode variar de forma significativa, pois não há padrão na moagem das industrias de soja (tabela 1) podendo conter $29-51 \%$ de celulose, $10-25 \%$ de hemicelulose, $1-9 \%$ de lignina e 9-14\% de proteína essa, sendo uma boa fonte de açúcares fermentescíveis, devido ao baixo teor de lignina (ROJAS, 2012). 
TABELA 1 - COMPOSIÇÃO QUÍMICA DA CASCA DE SOJA.

\begin{tabular}{|c|c|c|c|}
\hline Celulose (\%) & Hemicelulose (\%) & Lignina (\%) & Referências \\
\hline 38,4 & 10,2 & 2,8 & Mielenz et al., 2009 \\
\hline 39,7 & 25,5 & 9,1 & Cassales et al., 2011 \\
\hline 51,9 & 10,4 & 9,4 & Siqueira et al., 2010 \\
\hline
\end{tabular}

Considerada como um resíduo derivado da produção de óleo de soja, farelo de soja e outros produtos com alto teor de proteína, a casca de soja tem uma considerável importância na alimentação de ruminantes (principalmente onde a escassez de forragens torna-se o fator preponderante que limita a produtividade desses animais), como também de suínos. Sendo considerada uma fibra altamente fermentescível podendo ser utilizado como fonte de energia (ANDRADE e QUADROS, 2011; MIELENZ; BARDSLEY; WYMAN, 2009; ZAMBOM, et al., 2001).

Devido a existência de um mercado para a casca de soja como alimento de ruminantes, a utilização do resíduo para a produção de GH ainda é pouco estudada. Ademais, a conversão dos carboidratos da casca de soja em açúcares fermentescíveis pode resultar em uma significante quantidade de etanol (MIELENZ; BARDSLEY; WYMAN, 2009). Mielenz e colaboradores (2009) demostraram que a casca de soja é um resíduo agroindustrial que não necessita de um extenso pré-tratamento para que as enzimas hidrolíticas possam degradar os polímeros de carboidrato, uma vez que pouca quantidade de lignina é encontrada na casca de soja, sendo requeridas apenas celulases e $\beta$ glicosidases para uma significante despolimerização do complexo de carboidratos e posterior produção de etanol por S. cerevisae. Do mesmo modo, estudos realizados por Infante (2014) e Sciuto (2015) mostraram o potencial deste resíduo agroindustrial em produzir enzimas hidrolíticas com grande capacidade de aplicações biotecnológicas.

\section{JUSTIFICATIVA}

Devido à natureza complexa da parede celular, a degradação da biomassa lignocelulósica requer o uso de uma variedade de classes de enzimas que atuam sinergicamente para a degradação completa dos polissacarídeos. Diferente de outros tipos de biomassa lignocelulósica, a utilização da casca de soja como resíduo agroindustrial 
para a produção de mananases, não necessita de severos tratamentos, uma vez que a pequena quantidade de lignina presente neste resíduo é um fator chave para que as enzimas hidrolíticas sejam capazes de despolimerizar o complexo de carboidrato.

Microrganismos responsáveis pela degradação da celulose e hemicelulose podem ser encontrados livres na natureza ou como parte do sistema digestivo de alguns animais. A necessidade de se estudar enzimas capazes de hidrolisar a parede celular se dá não só pelas diferenças encontradas na composição da parede celular vegetal, mas também pela necessidade de se utilizar essas ferramentas em processos biotecnológicos. Vários fungos filamentosos capazes de produzir mananases em diferentes tipos de resíduos são descritos na literatura, em contrapartida, não há muitos estudos sobre as enzimas hidrolíticas produzidas por C. byssicola. Dessa maneira, o estudo dessas enzimas é de grande importância para posteriores aplicações industriais.

Dada à importância biotecnologia aplicada a mananase, o fungo C. byssicola foi utilizado como alvo de pesquisa para a produção de mananases, em cultivo submerso contendo casca de soja como fonte de carbono.

\section{OBJETIVOS}

O presente trabalho tem como objetivos investigar o potencial da casca de soja como fonte de carbono para produção de mananases por Clonostachys byssicola em cultivo submerso, assim como semi-purificar e caracterizar amostras de $\beta$-mananases.

\section{MATERIAIS E MÉTODOS}

\subsection{MICRORGANISMO}

Clonostachys byssicola foi obtido por meio de amostras de solo coletadas em uma fazenda no entorno do Distrito Federal em área de cerrado preservada. Foi feita a identificação molecular pela Dra. Rosane Mansan Almeida, do Laboratório de Microbiologia sob a supervisão do Prof. Dr. Robert Neil Gerard Miller. Este fungo faz parte da micoteca do Laboratório de Enzimologia da Universidade de Brasília, UnB, a autorização de acesso e de remessa de amostra de componente do patrimônio genético $\mathrm{n}^{\circ}$ 010237/2015-1. A micoteca também foi depositada no banco de microrganismos para controle de patógenos e plantas daninhas da Empresa Brasileira de Pesquisa Agropecuária 
(Embrapa). A micoteca do laboratório de Enzimologia é também registrada no Centro Mundial de Dados para Micro-organismos (WDCM), sob o código MCPPW 1128. O isolado foi cultivado em placas de Petri contendo meio ágar batata dextrose (BDA) com $10 \%$ de batata, $1 \%$ de dextrose e $2 \%$ de ágar e mantido em temperatura ambiente até a esporulação.

\subsection{FONTE DE CARBONO}

A casca de soja obtida da fazenda tropical em Cabeceiras, GO, é proveniente da espécie Glicine max. O material foi submetido a pré-tratamento, na qual $100 \mathrm{~g}$ da casca de soja foi autoclavado em erlenmeyer contendo $2 \mathrm{~mL}$ de água destilada a $12{ }^{\circ} \mathrm{C}$ por 1 h. Em seguida, a casca de soja foi lavada em água corrente e colocada para secar em estufa a $60{ }^{\circ} \mathrm{C}$ por $36 \mathrm{~h}$. Após esse procedimento, a casca de soja foi triturada em moinho de bancada, embalada em saco plástico e armazenada em caixa de isopor à temperatura ambiente.

\subsection{CULTIVO DO FUNGO}

Para o meio líquido suplementar utilizou-se a seguinte composição (g/v): 0,7\% de fosfato de potássio monobásico, $0,2 \%$ de fosfato de potássio dibásico, $0,01 \%$ de sulfato de magnésio 7 vezes hidratado, $0,1 \%$ de sulfato de amônio, $0,06 \%$ de extrato de levedura e $1 \%$ de casca de soja em um volume final de 1 litro de água destilada em $\mathrm{pH}$ 7,0. Em seguida o meio foi autoclavado por $30 \mathrm{~min}$ a $120^{\circ} \mathrm{C}$.

$\mathrm{Na}$ contagem de esporos em câmara de Neubauer, os esporos foram raspados das placas de Petri e com o auxílio de uma lâmina microscópica foram transferidos para $50 \mathrm{~mL}$ de solução salina $(0,9 \%$ de $\mathrm{NaCl}$ e $1 \mathrm{~mL}$ de Tween 80 a 1\%). Após a contagem, alíquotas da suspensão de esporos contendo $10^{7}$ esporos por $\mathrm{mL}$ foram inoculadas no meio suplementar (correspondendo a $1 \%$ do volume do meio).

O cultivo submerso foi realizado em quadruplicata biológica a $28^{\circ} \mathrm{C}$ sob agitação (120 rpm) por sete dias em frascos erlenmeyer de 1 litro, contendo $300 \mathrm{~mL}$ de meio. Após o cultivo, o meio foi filtrado a vácuo em funil de Büchener com papel filtro Whatman $\mathrm{n}^{\circ}$ 5. O material filtrado, denominado extrato bruto, e contendo enzimas secretadas pelo fungo, foi coletado (com adição de azida sódica na concentração de 0,02\%) e armazenado em câmara fria $\left(4^{\circ} \mathrm{C}\right)$. 


\subsection{SUBSTRATOS}

Os seguintes substratos foram utilizados nos ensaios enzimáticos: manana $1 \%$ (galactomanana - locust bean), xilana 1\% (oat spelt xylan), carboximetil-celulose 4\% (CMC), pectina 1\% (citrus fruit). Adquiridos da Sigma - Aldrich (St. Louis, MO. USA).

\subsection{DETERMINAÇÃO DA ATIVIDADE ENZIMÁTICA E CONCENTRAÇÃO PROTEÍCA}

Foram realizados microensaios em triplicata para a determinação das atividades enzimáticas de mananase, xilanase, CMCase e pectinase. A mistura de reação, contendo $5 \mu \mathrm{L}$ da solução enzimática e $10 \mu \mathrm{L}$ do substrato, foi incubada por 30 min a $50{ }^{\circ} \mathrm{C}$ (FERREIRA FILHO et al., 1993, com modificações). Após o tempo de incubação, o ensaio enzimático foi interrompido através da adição de $30 \mu \mathrm{L}$ de ácido 3,5-DinitroSalicílico (DNS) e posterior incubação por 10 min a $97^{\circ} \mathrm{C}$ (MILLER, 1959). Em seguida, $150 \mu \mathrm{L}$ de água destilada foram adicionados às amostras e realizada a leitura a $540 \mathrm{~nm}$ no espectrofotômetro (SpectraMax M2, Molecular Devices Co., EUA). Para o branco da enzima o substrato foi substituído por água destilada, em contrapartida, para o branco do substrato a enzima foi substituída por água destilada. As atividades enzimáticas foram expressas em UI/mL de solução enzimática, sendo UI definido como a quantidade de açúcar redutor $(\mu \mathrm{mol})$ liberado por minuto.

Para a determinação da quantidade de açúcar redutor liberado durante os ensaios enzimáticos, foram construídas curvas de calibração com os monossacarídeos que formam as cadeias principais dos polissacarídeos utilizados. Soluções estoques ( $2 \mathrm{mg} / \mathrm{mL})$ foram utilizadas para cada açúcar redutor (glicose, manose, xilose e ácido galacturônico) variando a concentração final do açúcar redutor $(0,1 \mathrm{mg} / \mathrm{mL}-1,4 \mathrm{mg} / \mathrm{mL})$ com um volume final de $15 \mu \mathrm{L}$. Os ensaios foram realizados em triplicatas. Após a adição do açúcar redutor, água destilada e DNS, a mistura de reação foi incubada a $97{ }^{\circ} \mathrm{C}$ e, subsequentemente, $150 \mu \mathrm{L}$ de água destilada foram adicionados na mistura de reação para a leitura a $540 \mathrm{~nm}$ no espectrofotômetro.

A determinação da quantidade de proteína foi realizada pelo método de Bradford (BRADFORD, 1976), utilizando o kit Protein assay (Bio-Rad Laboratories, EUA). 


\subsection{ULTRAFILTRAÇÃO}

O extrato bruto foi concentrado 10 vezes utilizando o sistema de ultrafiltração do tipo Amicon com membranas de retenção de 30 kDa (PM 30 Milipore Co., Ma, EUA), pressão de $5 \mathrm{~kg} . \mathrm{f} / \mathrm{cm}^{2}$ e temperatura de $4{ }^{\circ} \mathrm{C}$.

\subsection{PURIFICAÇÃO PARCIAL}

As amostras concentradas por ultrafiltração foram submetidas à cromatografia de troca aniônica do tipo DEAE Sepharose Fast Flow $(2,6 \times 6 \mathrm{~cm})$. A coluna foi previamente lavada com água destilada e equilibrada com tampão fosfato de sódio $\mathrm{pH}$ 7,0 $(50 \mathrm{mM})$ contendo $0,01 \%$ de azida sódica. Foram aplicados $10 \mathrm{~mL}$ de amostra na coluna frações de $5 \mathrm{~mL}$ foram eluídas com um fluxo de $0,33 \mathrm{~mL} / \mathrm{min}$. A eluição foi realizada em tampão fosfato de sódio $\mathrm{pH}$ 7,0 $(50 \mathrm{mM})$ e por meio de um gradiente de sal $(\mathrm{NaCl})$ de 0 a $50 \mathrm{mM}$. Posteriormente, foram realizados microensaios enzimáticos para a detecção das atividades de mananase, CMCase, xilanase e pectinase nas frações coletadas.

As frações contendo atividade de mananase foram coletadas (fração ManDEAE) e aplicadas em coluna de troca aniônica do tipo HiTrap Q Sepharose Fast Flow (QFF 1 mL) acoplada ao sistema de purificação $\ddot{k} k t a$ (GE Helthcare). A priori, a coluna foi lavada com água mili-Q, em seguida, a coluna foi equilibrada com tampão fosfato de sódio pH $7(50 \mathrm{mM})$. Foi aplicado $1 \mathrm{~mL}$ de amostra enzimática na coluna e frações de $1 \mathrm{~mL}$ foram coletadas com o fluxo de $1 \mathrm{~mL} / \mathrm{min}$. A eluição foi realizada em tampão fosfato de sódio pH 7,0 $(50 \mathrm{mM})$ e por meio de um gradiente de sal $(\mathrm{NaCl})$ de 0 a $50 \mathrm{mM}$. As frações contendo atividade de mananase foram reunidas (ManQFF) e utilizadas para posteriores caracterizações.

O perfil de proteína total foi determinado pela leitura das frações no comprimento de onda de $280 \mathrm{~nm}$ em Spectramax M2 (Molecular Devices).

\subsection{ELETROFORESE E ZIMOGRAFIA}

O grau de pureza das amostras enzimáticas foi analisado por eletroforese em gel de poliacrilamida, conforme descrito por Laemmli (1970). As proteínas foram previamente submetidas a precipitação em solução de ácido tricloroacético (TCA) $10 \%$ e incubadas a $4{ }^{\circ} \mathrm{C}$ por $1 \mathrm{~h}$. Em seguida, as amostras foram centrifugadas a $14000 \mathrm{rpm}$ por 
15 min a $4{ }^{\circ} \mathrm{C}$. Posteriormente, o sobrenadante foi removido e as amostras foram lavadas 3 vezes com $1 \mathrm{~mL}$ de acetona refrigerada e centrifugadas nas mesmas condições anteriores. Por fim, o sobrenadante foi descartado e as amostras foram submetidas a secagem na temperatura ambiente.

As amostras enzimáticas precipitadas foram ressuspensas em tampão de amostra 1x (Tris-HCL 125 mM pH 6,8; SDS 2,0\%; azul de bromofenol 0,05\%; glicerol 20\% e $\beta$ mercaptoetanol 5,0\%). As amostras enzimáticas foram aquecidas por 3 min a $100{ }^{\circ} \mathrm{C}$, e submetidas à eletroforese em gel de poliacrilamida $12 \%$.

A visualização de proteínas foi realizada por coloração com nitrato de prata. $\mathrm{O}$ gel foi incubado em uma solução fixadora (v/v de metanol $40 \%$ e ácido acético $12 \%$ ) durante o período de $1 \mathrm{~h}$, posteriormente o gel foi lavado três vezes com etanol $50 \%(\mathrm{v} / \mathrm{v})$ e incubado por 1 min em solução de tiossulfato de sódio $0,02 \%(\mathrm{~m} / \mathrm{v})$. A solução de tiossulfato foi removida por lavagens sucessivas de água destilada. $\mathrm{O}$ gel foi incubado por $15 \mathrm{~min}$ em solução de $0,2 \%(\mathrm{~m} / \mathrm{v})$ nitrato de prata contendo $0,074 \%(\mathrm{v} / \mathrm{v}) \mathrm{de}$ formaldeído (lavado três vezes com água destilada, e mantido em solução reveladora 6\% $(\mathrm{m} / \mathrm{v})$ de carbonato de sódio, 0,0004 (v/v) de tiossulfato e 0,05\% (v/v) de formaldeído). A reação foi interrompida pela adição de solução fixadora (BLUM; BEIER; GROSS, 1987).

Para realização do zimograma, o gel foi copolimerizado com o substrato (manana 1\%) em uma concentração final de $0,1 \%$ do substrato. As amostras foram precipitadas com TCA e ressuspensas em tampão de amostra, como descrito anteriormente. Após a corrida, o gel foi incubado 2 vezes em solução Triton 100x 2,5\% por $30 \mathrm{~min}$. A posteriori, o gel foi incubado em solução de acetato de sódio $(50 \mathrm{mM}) \mathrm{pH}$ 5,5 por duas vezes durante 30 min e mantido no mesmo tampão por $1 \mathrm{~h}$ e 30 min a $50^{\circ} \mathrm{C}$. A reação foi interrompida por incubação do gel em câmara fria por $30 \mathrm{~min}$. Por fim, o gel foi revelado em solução de vermelho congo $1 \%$ e descorado em solução $1 \mathrm{M}$ de $\mathrm{NaCl}$ e ácido acético $0,5 \%$.

\subsection{CARACTERIZAÇÃO ENZIMÁTICA}

\subsubsection{Efeito da temperatura e $\mathrm{pH}$}

O efeito da temperatura na atividade de mananase foi avaliado por incubação da enzima em um intervalo de temperatura de 30 a $80{ }^{\circ} \mathrm{C}\left(\Delta=0,5^{\circ} \mathrm{C}\right)$. $\mathrm{O}$ extrato bruto 
concentrado por ultrafiltração e a fração semi-purificada (QFF) foram submetidos a microensaios como descrito no item 4.7. Para a determinação do pH ótimo, a manana $1 \%$ foi tamponada com tampão universal a $50 \mathrm{mM}$ (glicina, fosfato e citrato) em uma ampla faixa de $\mathrm{pH}(3,5-9,0)$, em seguida foram realizados microensaios em triplicata como descrito anteriormente no item 4.7 .

\subsubsection{Avaliação da termoestabilidade}

A fim de avaliar a estabilidade térmica de mananase, o extrato bruto concentrado e a fração semi-purificada (QFF) foram incubados em tubos de $2 \mathrm{~mL}$, na ausência de substrato, em diferentes temperaturas $\left(40,50\right.$ e $\left.55^{\circ} \mathrm{C}\right)$. A posteriori, foram retiradas alíquotas e determinada a meia vida de mananase, por microensaios enzimáticos realizados em triplicatas.

\subsubsection{Determinação dos parâmetros cinéticos}

Para a determinação dos parâmetros cinéticos $\left(\mathrm{K}_{\mathrm{M}}\right.$ e $\left.\mathrm{V}_{\mathrm{max}}\right)$, foi preparada uma solução de manana, diluída em tampão acetato de sódio pH 5 (50 mm), com uma concentração final de $26,5 \mathrm{mg} / \mathrm{mL}$ e, posteriormente, essa solução foi diluída no intervalo de concentração de $0,5-26,5 \mathrm{mg} / \mathrm{mL}$. Foram realizados microensaios utilizando valores fixos da enzima $(5 \mu \mathrm{L})$ e diferentes concentrações do substrato. A constante de Michaelis e Menten $\left(\mathrm{K}_{\mathrm{M}}\right)$ e a velocidade máxima $\left(\mathrm{V}_{\text {máx }}\right)$ foram determinadas utilizando o software Enzifitter (LEATHERBARROW, 1999). Os ensaios foram realizados em triplicata.

\subsubsection{Efeito de íons metálicos e EDTA na atividade de mananase}

A influência dos íons metálicos e EDTA na atividade de mananase foi avaliada pela pré-incubação das amostras enzimática por 20 min (temperatura ambiente) na presença de diversos compostos em concentrações finais de 1 e $10 \mathrm{mM}$. Os íons utilizados para o ensaio foram: $\mathrm{AgNO}_{3}, \mathrm{CaCl}_{2}, \mathrm{CoCl}_{2}, \mathrm{CuSo}, 4 \mathrm{FeCl}_{3}, \mathrm{FeSO}_{4}, \mathrm{KCl}, \mathrm{MgCl}_{2}, \mathrm{MgSO}_{4}$ e $\mathrm{ZnSO}_{4}$. Como controle, os reagentes foram substituídos por água destilada. A atividade residual foi expressa como atividade relativa, no qual o valor de $100 \%$ correspondeu a atividade enzimática na ausência dos íons e EDTA. 
4.9.5 Efeito de compostos fenólicos na atividade de mananase

O efeito dos compostos fenólicos foi realizado utilizando os seguintes reagentes: vanilina e ácido tânico (dissolvidos em água); ácido 4-hidroxibenzóico, ácido ferúlico, ácido p-coumárico e ácido cinâmico (dissolvidos em etanol). As amostras enzimáticas contendo atividade de mananase foram pré-incubadas com os compostos fenólicos na concentração de $1 \mathrm{mg} / \mathrm{mL}$, em temperatura ambiente, por $20 \mathrm{~min}$. Em seguida foram realizados microensaios enzimáticos para a determinação de atividade relativa. Como controle, os reagentes foram substituídos por água ou etanol 50\%. Os ensaios foram realizados em triplicata.

\subsection{HIDRÓLISE ENZIMÁTICA}

As amostras do extrato bruto concentrado foram incubadas com a manana $1 \% \mathrm{e}$ a casca de soja em tubos de $2 \mathrm{~mL}$ por quatro dias (na proporção de 1:2 de amostra/substrato). Os ensaios de hidrólise foram realizados em vortemp (Labnet) sob agitação de $720 \mathrm{rpm}$ a $40^{\circ} \mathrm{C}$. Para os ensaios de hidrólise, alíquotas de $70 \mu \mathrm{L}$ foram retiradas durante o período de 0, 8, 24, 48, 72 e 96 horas de incubação. Em seguida, as amostras foram fervidas e quantificadas por meio do método DNS. Após o ensaio, as amostras foram armazenadas a $-20^{\circ} \mathrm{C}$, para posteriores análise por HPLC (Cromatografia líquida de alta performance). No controle enzimático, as amostras enzimáticas foram incubadas em tampão acetato de sódio pH 5,0 (50 mM) na ausência de substrato, do mesmo modo, o controle do substrato foi incubado com o mesmo tampão na ausência da enzima.

4.10.1 Análise por HPLC das amostras do ensaio de hidrólise

Alíquotas provenientes dos ensaios de hidrólise foram utilizadas para a análise em cromatografia líquida de alta eficiência de troca aniônica, acoplada a um detector de amperometria pulsada (HPAE-PAD), com o intuito de quantificar e identificar manooligossacarídeos liberados. Durante o ensaio de hidrólise, as amostras foram analisadas em sistema Dionex Dionex ICS 3000 DC Ion Chromatography com utilização de précoluna CarboPac Guard e coluna CarboPac PA-100 (Dionex Corporation, Sunnyvale, CA, EUA). Foram injetados $10 \mu \mathrm{L}$ de amostra com o auto sampler AS40 (Dionex), com 
o fluxo de $15 \mathrm{~mL} / \mathrm{min}$. As amostras foram eluídas em solução de hidróxido de sódio $(0,1$ M) e solução de acetato de sódio $(0,5 \mathrm{M})$. Os dados obtidos foram analisados pelo software Chromeleon 6.8 SR8 (Dionex).

Foram preparadas curvas de calibração para a quantificação de manooligossacarídeos. A priori, foram feitas várias soluções com os diferentes manooligossacarídeos (manose, manobiose, manotriose, manotetraose, manopentose e monohexose) na concentração final de $1 \mathrm{mg} / \mathrm{mL}$. Posteriormente, foi feito um mix contendo todos os mano-oligossacarídeos com concentrações distintas (variando de 0,0025-0,005 mg/mL).

Para todos os experimentos realizados foram calculados o erro padrão, sendo este inferior a $10 \%$. 


\subsection{ESQUEMA DA PURIFICAÇÃO PARCIAL DE MANANASE PRODUZIDA} POR C. byssicola.

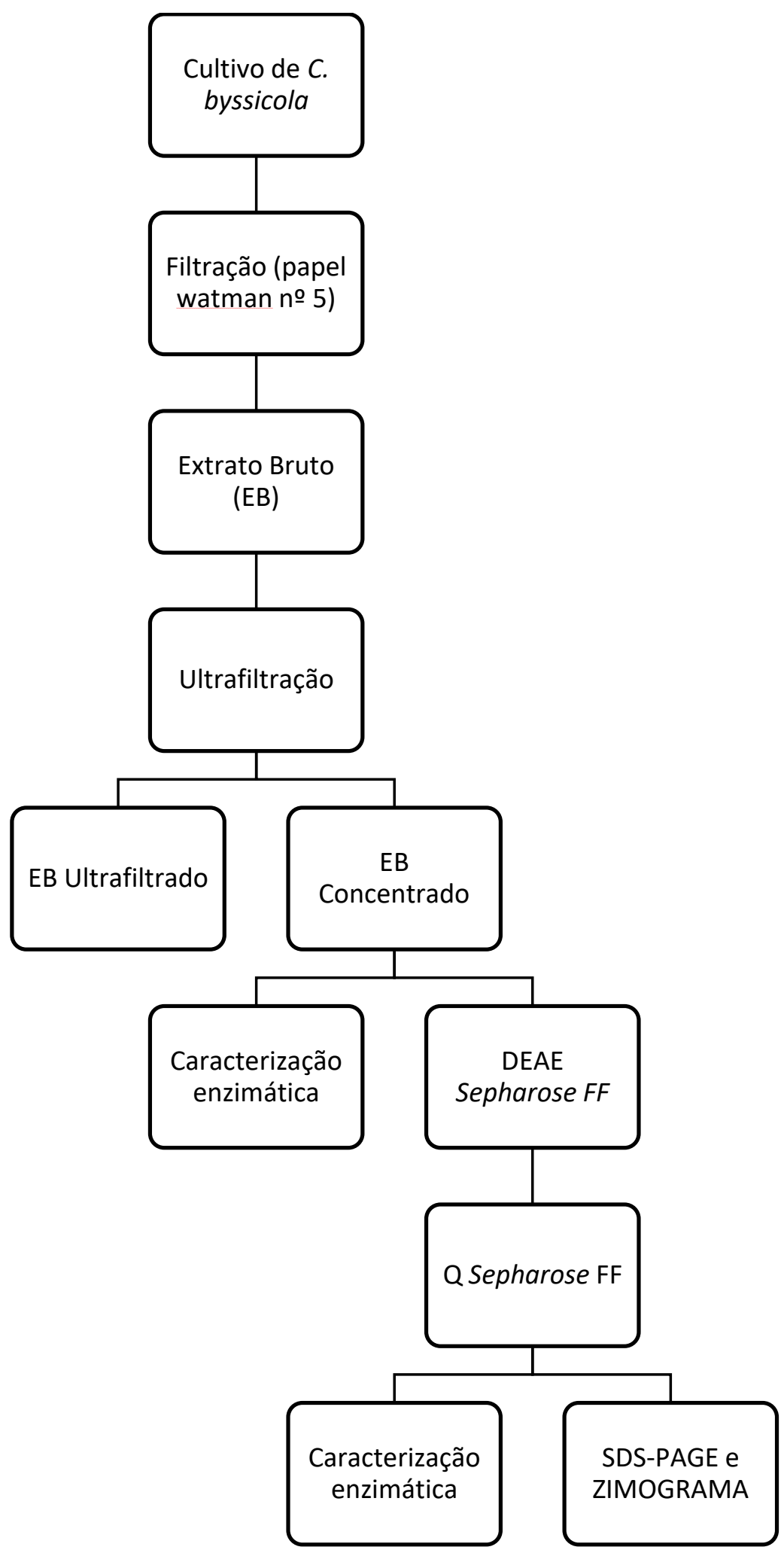

Figura 12: Esquema da purificação parcial e caracterização de $\beta$-mananase de $C$. byssicola crescido em casca de soja. 


\section{RESULTADOS E DISCUSSÕES}

\subsection{CULTIVO DO FUNGO}

Em estudos posteriores, a fim de avaliar o perfil da secreção enzimática de $C$. byssicola crescido em casca de soja, Sciuto (2015) mostrou que no sétimo dia de cultivo, o fungo apresentou maior atividade enzimática de mananase. O cultivo de $C$. byssicola em meio líquido suplementado com a casca de soja como fonte de carbono, durante o período de sete dias, produziu mananases com atividade de 0,41 UI/mL. Estes resultados corroboram com pesquisas realizadas por Gomes (2014), mostrando que a casca de soja é uma fonte de carbono indutora de mananase em virtude da grande quantidade de manana presente na estrutura do resíduo. Ademais, Infante (2014), demonstrou que o cultivo do fungo A. foetidus em meio submerso contendo casca de soja como fonte de carbono, apresentou maior atividade de mananase do que em resíduos da colheita de soja.

Weingartner (2010), otimizou as condições fermentativas para a produção de mananases, por meio das técnicas de fermentação no estado sólido (FES) e em biorreatores, utilizando a casca de soja como fonte de carbono para o crescimento de $A$. niger. $\mathrm{O}$ fungo apresentou um aumento da atividade de mananase até o quarto dia de cultivo em FES, em contrapartida, a maior atividade de mananase produzida em biorreatores foi alcançada no sexto dia de cultivo.

A produção de outros tipos de enzimas hidrolíticas capazes de degradar a casca de soja pode ser encontrada em pesquisas realizadas por Kalapathy e Proctor (2001). Estes autores mostraram que a casca de soja contém porcentagens de pectina comparável ao teor de pectina dos produtos cítricos, o que favorece a indução de enzimas pectinolíticas. Além do mais, a casca de soja pode ser armazenada e transportada sem processamentos adicionais. Em contraste, as cascas cítricas necessitam de processos de secagem para evitar a deterioração. Do mesmo modo, Brijawani e colaboradores (2010) produziram altos níveis de celulases utilizando a casca de soja como indutor dessas enzimas.

\subsection{ULTRAFILTRAÇÃO}

A ultrafiltração é um processo de separação de moléculas, no qual devido a diferença de pressão aplicada, as moléculas dos solventes e solutos com massa molecular 
inferior ao corte da membrana permeiam através dos poros da membrana. Em contrapartida, partículas maiores são retidas (RODRIGUES et al., 2003). Após o cultivo, durante o período de sete dias, o extrato bruto foi submetido à ultrafiltração com uma membrana de retenção de $30 \mathrm{kDa}$. Foram obtidas duas frações: concentrada e ultrafiltrada. A maior parte da atividade de mananase foi encontrada na fração concentrada (tabela 2), sendo a mesma escolhida para realização de estudos posteriores

TABELA 2- RESULTADOS OBTIDOS A PARTIR DA ULTRAFILTRAÇÃO DO EXTRATRO BRUTO DE C. byssicola.

\begin{tabular}{|c|c|}
\hline Amostra & Atividade (UI/mL) \\
\hline Extrato bruto & 0,41 \\
\hline Concentrado (PM 30 kDa) & 4,18 \\
\hline Ultrafiltrado (PM 30 kDa) & 0,11 \\
\hline
\end{tabular}

A ultrafiltração tem sido utilizada como importante ferramenta para concentração de enzimas com alta recuperação de atividade (POLLETO, 2015), SiikaAho e colaboradores (1993), utilizaram membranas de 10 e $25 \mathrm{kDa}$ recuperando por volta de $76 \%$ de mananases presente no extrato bruto. Cheng et al. (2016) conseguiram recuperar por ultrafiltração $89 \%$ de mananases utilizando membrana $10 \mathrm{kDa}$. Ademais, Infante (2014) conseguiu recuperar 100\% da atividade de mananase presente no extrato bruto também utilizando uma membrana de $10 \mathrm{kDa}$. A maioria desses estudos utilizam a ultrafiltração como etapa inicial para facilitar a posterior purificação de mananases por diferentes tipos de cromatografia (POLLETO, 2015).

\subsection{PURIFICAÇÃO PARCIAL DE MANANASE POR CROMATOGRAFIA DE TROCA IÔNICA}

A purificação parcial foi realizada à temperatura ambiente. A amostra do extrato bruto, concentrado por ultrafiltração, com membrana de retenção de $30 \mathrm{kDa}$ foi aplicada em coluna de troca aniônica do tipo DEAE Sepharose Fast Flow. Na figura 13, podemos observar três picos de atividade de mananase: o primeiro pico elui nas primeiras frações do cromatograma (frações 7-10). Junto com a mananase, foram detectadas atividades de CMCase, xilanase e pectinase (dados não mostrados). Posteriormente, dois picos de 
mananases foram eluidos durante o gradiente de $\mathrm{NaCl}$ entre as frações $28-33$ e 40-43, respectivamente. No segundo e terceiro pico a sobreposição de outras enzimas foi menor, contudo, apenas o terceiro pico foi selecionado para etapas posteriores, devido a maior atividade de mananase.

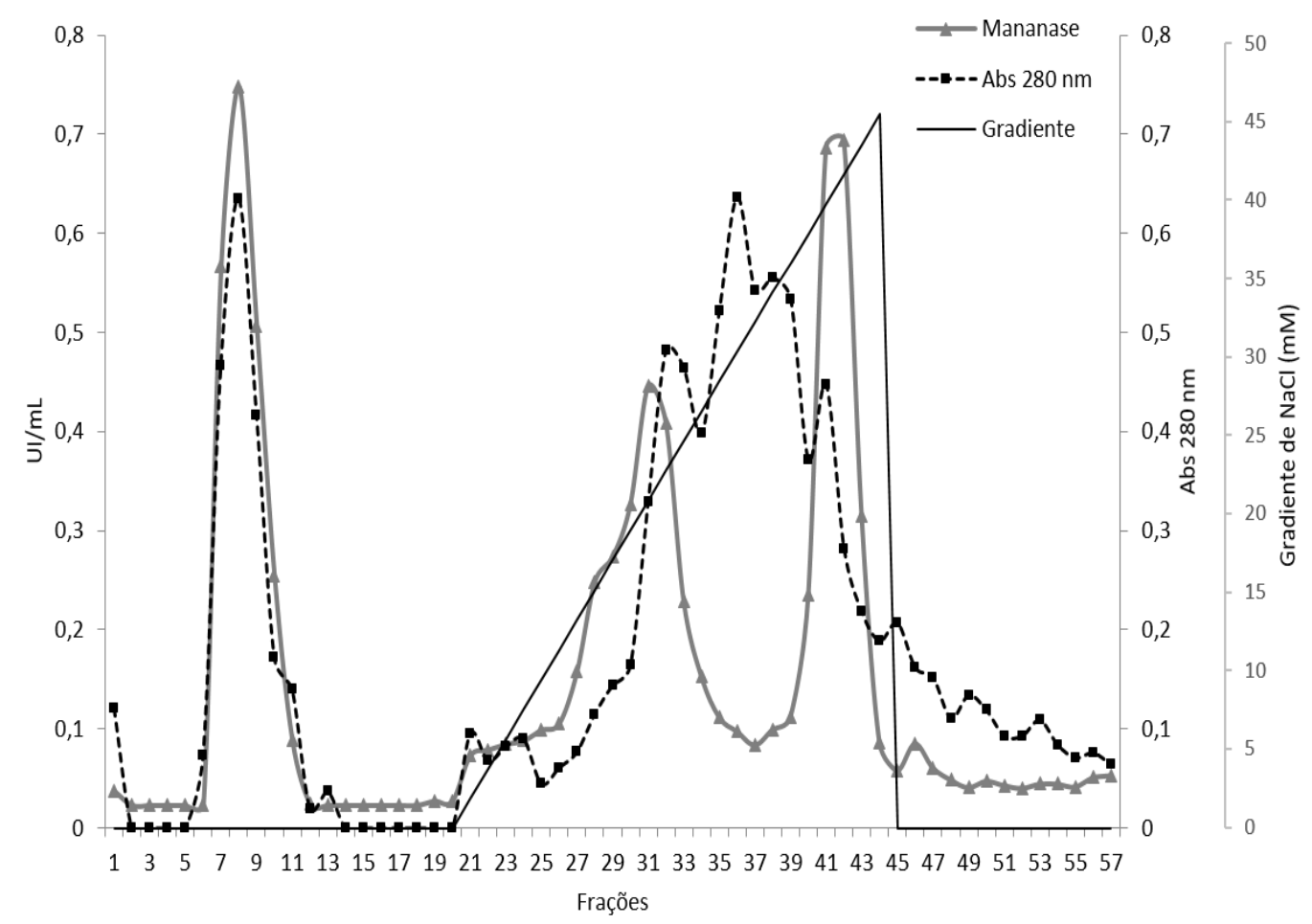

Figura 13. Perfil cromatográfico do EBC em cromatografia de troca aniônica (DEAE Sepharose Fast Flow).

As frações 40-43 (ManDEAE) foram reunidas e aplicadas em coluna de troca aniônica do tipo QFF Sepharose Fast Flow (fig. 14). Nesse caso, o perfil cromatográfico foi similar ao anterior. Na QFF foram detectados três picos contendo atividade de mananase: o primeiro pico corresponde a fração 2 do cromatograma, constituída de enzimas que não se ligaram ao grupo carregado (amina quaternária) da resina. Contudo, o segundo (frações 19-21) e o terceiro pico (fração 26) foram eluidos durante o gradiente de $\mathrm{NaCl}$. No segundo pico (ManQFF), co-eluíram enzimas com atividade de CMCase e Xilanse, inferior a $0,18 \mathrm{UI} / \mathrm{mL}$ (dados não mostrados). Ambos os picos se sobrepõe ao pico de proteína indicando a necessidade de passos adicionais para completa purificação de mananase.

A pureza das frações e o número aproximado de enzimas pode ser visualizado na figura 15. A multiplicidade de proteínas que eluíram no cromatograma é exibida no 
gel SDS-PAGE, como observado, a quantidade de proteínas ao longo das técnicas de purificação não diminuíram de forma significativa, necessitando de passos adcionais para obtenção da enzima pura. Com base na degradação do substrato copolimerizado, o zimograma apresentou várias proteínas com atividade mananase. $\mathrm{O}$ tamanho da enzima foi determinado pela sua migração relativa, mostrando que proteoformas de mananase são produzidas por $C$. byssicola e apresentam tamanhos que variam de $36,6-53 \mathrm{kDa}$. Assim como C. byssicola, Hilge et al. (1996) identicou três mananases produzidas por Thermomonospora fusca, embora as enzimas apresentassem pontos isoelétricos equivalentes, a mesma temperatura, $\mathrm{pH}$ e modo de ação, os tamanhos moleculares das enzimas eram diferentes, alternando entre 38 e $47 \mathrm{kDa}$. De acordo com Hilge et al. (1996), possivelmente, essas diferenças de tamanho poderiam ser explicadas pelo grau de glicosilação, como também por outro tipo de processamento, como por exemplo a clivagem proteolítica dessas enzimas, uma vez que análises genômicas indicaram que as enzimas eram derivadas do mesmo gene. Da mesma forma, estudos realizados por Schröder et al. (2006) mostraram a presença de quatro proteoformas de mananases extraídas de tomate cru. De acordo com Lermyte e Sobott (2015) proteoformas podem ser resultantes do splicing alternativo do RNA, pela ocorrência de mutações específicas, e por modificações pós-traducionais. 


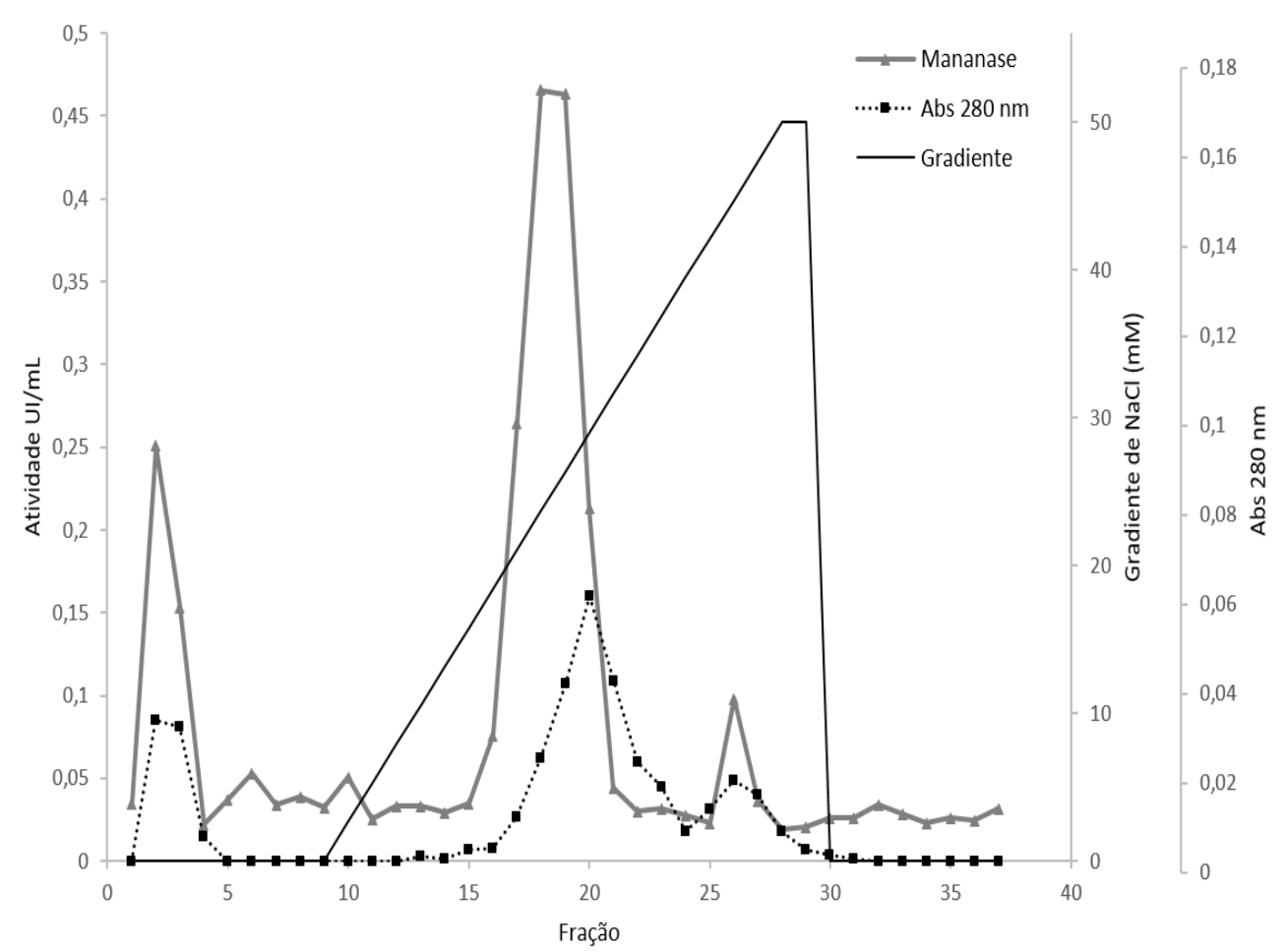

Figura 14. Perfil cromatográfico das frações ManDEAE em cromatografia de troca aniônica $Q$ Sepharose Fast Flow.

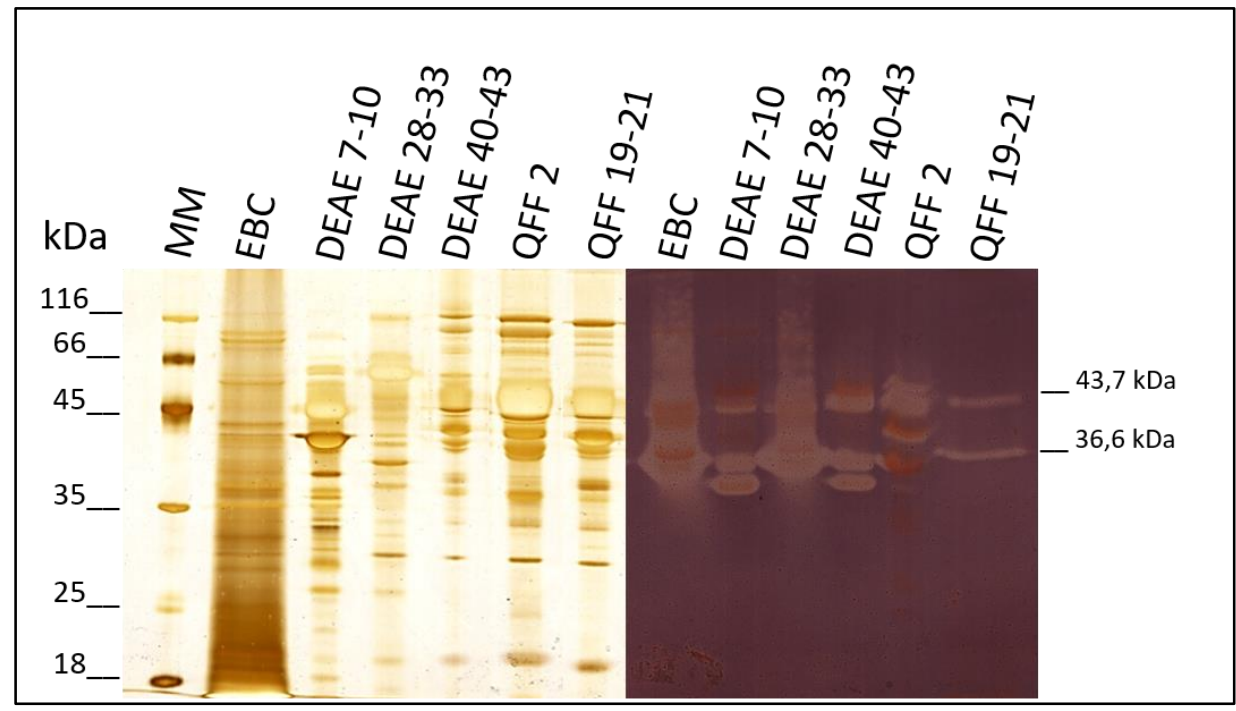

Figura 15. SDS-PAGE e Zimograma das frações das cromatografias de DEAE Sepharose Fast Flow e $Q$ Sepharose Fast Flow. Abreviações: MM, marcador molecular; EBC, extrato bruto concentrado.

A maioria das pesquisas sobre enzimas produzidas por microrganismos tem se concentrado no isolamento, purificação, caracterização e identificação dos produtos de degradação, como uma forma de entender o modo de ação das enzimas. Para a purificação 
de mananases é necessário um detalhamento bioquímico e molecular da enzima, assim como o conhecimento da sua estrutura química. A purificação de mananases é fundamentada na escolha de diversos tipos de combinações de procedimentos que proporcionem o isolamento da proteína alvo (MOREIRA e FERREIRA FILHO, 2008).

Lu et al. (2013) purificaram uma $\beta$-mananase de A. nidulans utilizando técnicas de ultrafiltração seguida de cromatografia de troca aniônica, obtendo uma mananase com tamanho molecular de $63 \mathrm{kDa}$. Inoue e colaboradores (2015) purificaram uma $\beta$ mananase de Talaromyces cellulolyticus por meio de cromatografias de troca iônica e de interação hidrofóbica obtendo uma enzima de 39,3 kDa. Uma mananase de $63 \mathrm{kDa}$ foi purificada por El-Sharouny et al. (2015) mediante a realização de cromatografias de troca aniônica e exclusão molecular. Soni et al. (2016a) purificaram uma $\beta$-mananase monomérica de $49 \mathrm{kDa}$ de A. terreus por meio de técnicas de ultrafiltração e cromatografias de troca iônica e e de exclusão molecular. Infante et al. (2015) semipurificaram uma $\beta$-mananase (Man58 de $45 \mathrm{kDa}$ ) por técnicas de ultrafiltração e cromatografia de exclusão molecular.

\subsection{CARACTERIZAÇÃO ENZIMÁTICA}

\subsubsection{Efeito da Temperatura e $\mathrm{pH}$}

Os efeitos da temperatura e $\mathrm{pH}$ sobre a atividade de mananase é demonstrado nas figuras 16 e 17, respectivamente. A avaliação desses parâmetros é de grande importância para a utilização industrial dessas enzimas, uma vez que os mesmos podem afetar a eficiência catalítica da enzima (SONI, et al., 2016a). Mananases microbianas são ativas em diferentes temperaturas que variam no intervalo de $37{ }^{\circ} \mathrm{C}-70^{\circ} \mathrm{C}$ (CHAUHAN et al., 2012). A amostra de mananase do extrato bruto concentrado apresentou maior atividade quando incubada a $55^{\circ} \mathrm{C}$ tendo uma diminuição da sua atividade em temperaturas maiores que $60^{\circ} \mathrm{C}$. Em contrapartida, a fração semi-purificada, ManQFF, exibiu maior atividade a $45^{\circ} \mathrm{C}$, tendo uma queda considerável em temperaturas maiores que $55^{\circ} \mathrm{C}$. 

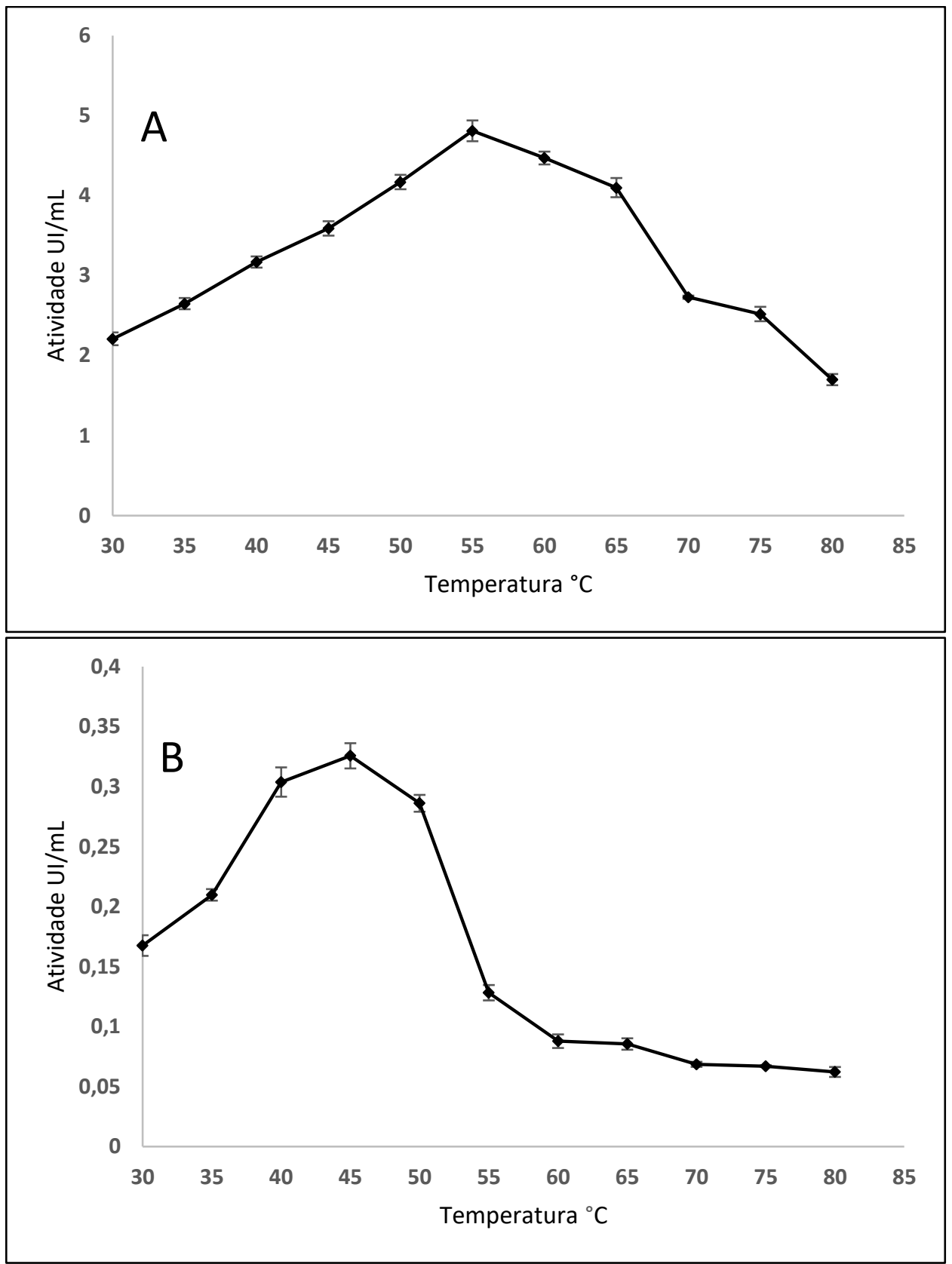

Figura 16. Efeito da temperatura na atividade de mananase. A: extrato bruto concentrado (EBC); B: fração semi-purificada ManQFF.

Quando incubada em diferentes faixas de $\mathrm{pH}$, a atividade de mananase do EBC não mostrou uma diferença significativa de atividade no intervalo de $\mathrm{pH}$ 5,0-6,5. Tendo uma redução da sua atividade em pH neutro e básico. Do mesmo modo, a fração semipurificada ManQFF manteve, consideravelmente, sua atividade entre o $\mathrm{pH} 5-6,5$, apresentando uma diminuição da sua atividade a partir do $\mathrm{pH}$ 7. Diferentes temperaturas e pH de mananase são mostrados na tabela 3 . 


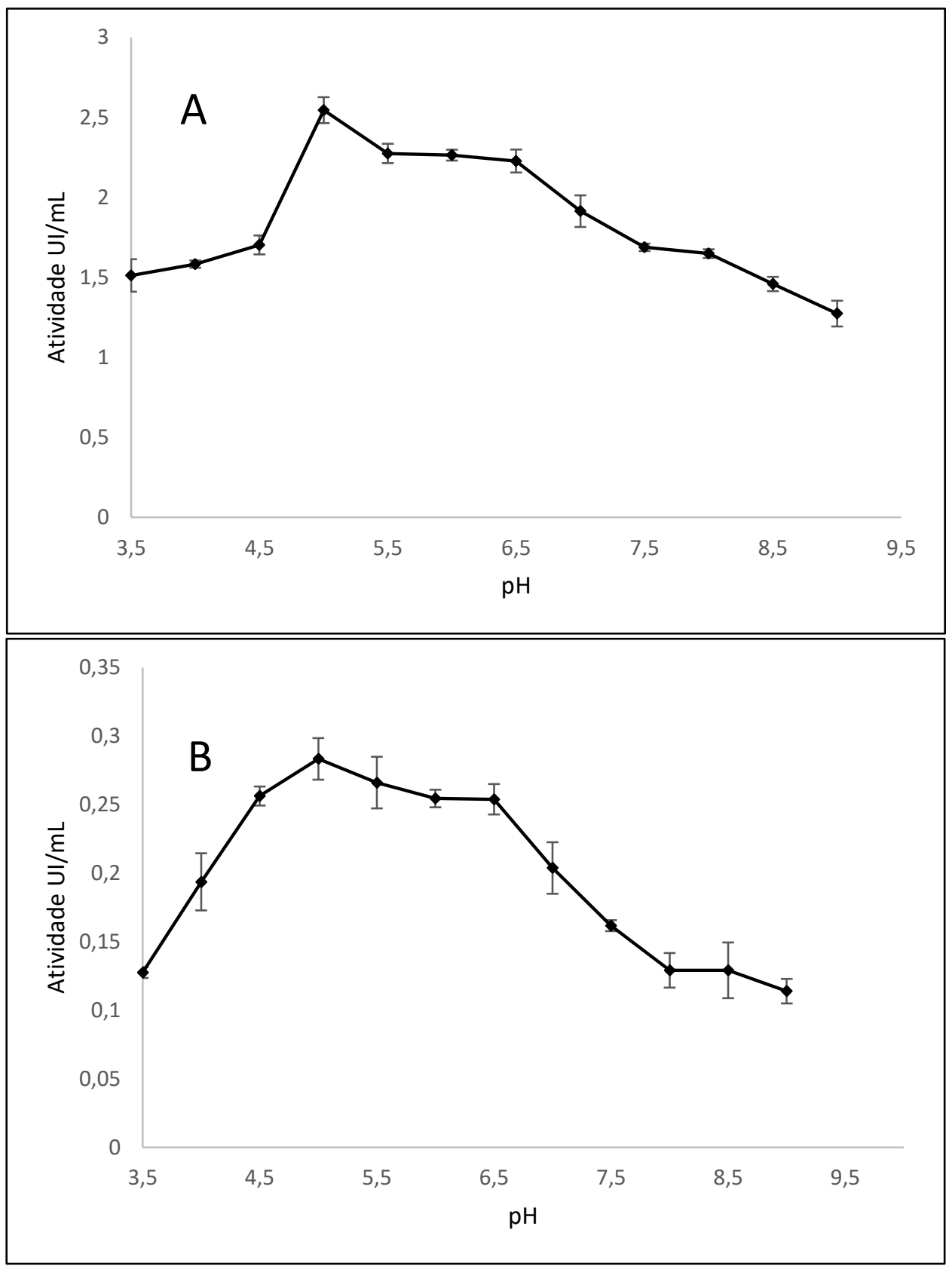

Figura 17. Efeito do $\mathrm{pH}$ na atividade de mananase. A: extrato bruto concentrado (EBC); B: fração semipurificada QFF. Tampão (glicina, fosfato e citrato). 
TABELA 3- pH E TEMPERATURA ÓTIMA DE MANANASE DESCRITA PARA DIFERENTES MICRORGANISMOS.

\begin{tabular}{|c|c|c|c|c|}
\hline Organismo & pH ótimo & $\begin{array}{c}\text { Temperatura } \\
\text { ótima }\end{array}$ & $\begin{array}{c}\text { Peso } \\
\text { molecular }\end{array}$ & Referência \\
\hline Aspergillus fumigatus & 4.5 & $65^{\circ} \mathrm{C}$ & $60 \mathrm{kDa}$ & Purchart, et al., 2004. \\
\hline Aspergillus fumigatus & 4.5 & $65^{\circ} \mathrm{C}$ & $63 \mathrm{kDa}$ & Purchart, et al., 2004. \\
\hline Orpinomyces sp. & 6.0 & $50^{\circ} \mathrm{C}$ & $55 \mathrm{kDa}$ & Ximenes, 2005. \\
\hline Aspergillus sulphureus & 2.5 & $50^{\circ} \mathrm{C}$ & $41.38 \mathrm{kDa}$ & Chen, et al., 2007. \\
\hline Biospora sp. MEY-I & 1 & $65^{\circ} \mathrm{C}$ & $46.8 \mathrm{kDa}$ & Luo, et al., 2009. \\
\hline Aspergillus niger & 5.5 & $30^{\circ} \mathrm{C}$ & - & Adesina, et al., 2013. \\
\hline Aspergillus nidulans & 5.0 & $80^{\circ} \mathrm{C}$ & $63 \mathrm{kDa}$ & Lu, et al., 2013. \\
\hline Bacillus pumilus & 8.0 & $60^{\circ} \mathrm{C}$ & 35 e $55 \mathrm{kDa}$ & Adiguzel, et al., 2014. \\
\hline Bacillus nealsonni & 8.8 & $65^{\circ} \mathrm{C}$ & $50 \mathrm{kDa}$ & Chauhan, et al., 2014. \\
\hline Penicillium oxalicum & 4.0 & $80^{\circ} \mathrm{C}$ & $61.6 \mathrm{kDa}$ & Liao, et al., 2014. \\
\hline Weissela viridescens & 5.0 & $40^{\circ} \mathrm{C}$ & $36.25 \mathrm{kDa}$ & Adiguzel, et al., 2015. \\
\hline Bacillus subtilis & 6.3 & $70^{\circ} \mathrm{C}$ & $41 \mathrm{kDa}$ & Li, et al., 2015. \\
\hline Bacillus subtilis & 6.5 & $55^{\circ} \mathrm{C}$ & $40 \mathrm{kDa}$ & Liu, et al., 2015 \\
\hline Aspergillus nidulans & 4.0 & $50^{\circ} \mathrm{C}$ & - & Shimizu, et al., 2015. \\
\hline Aspergillus niger & 4.5 & $80^{\circ} \mathrm{C}$ & $45 \mathrm{kDa}$ & Yu, et al., 2015. \\
\hline Neosartorya fischeri & 4.0 & $80^{\circ} \mathrm{C}$ & $43 \mathrm{kDa}$ & Yang, H., et al., 2015. \\
\hline Aspergillus nidulans & 5.5 & $80^{\circ} \mathrm{C}$ & $35.2 \mathrm{kDa}$ & Freiesleben, et al., 2016 \\
\hline Trichoderma reesei & 3.5 & - & $45.2 \mathrm{kDa}$ & Freiesleben, et al., 2016 \\
\hline Aspergillus terreus & 7.0 & $70^{\circ} \mathrm{C}$ & $49 \mathrm{kDa}$ & Soni, et al., 2016a. \\
\hline Bacillus subtilis & 6.0 & $65^{\circ} \mathrm{C}$ & $28.2 \mathrm{kDa}$ & Cheng, et al., 2016. \\
\hline
\end{tabular}


De acordo com a tabela 3, uma maior atividade tem sido relatada em $\mathrm{pH}$ ácidos para maioria das mananases de fungos filamentosos. Além do mais, temperaturas ótimas de mananases tem sido descrita no intervalo de $50-80^{\circ} \mathrm{C}$. Contudo, diferente dos fungos filamentosos, as bactérias apresentam maior atividade no intervalo de $\mathrm{pH}$ entre 6,0-8,0 e temperatura acima de $50^{\circ} \mathrm{C}$. Devido ao baixo valor de $\mathrm{pH}$ das mananases produzidas por C. byssicola, essas enzimas apresentam grande potencial como aditivos de rações de animais, uma vez que são necessárias enzimas que atuem em pH ácido para a eficiente hidrólise de galactomananas, como também enzimas que sejam resistentes a proteases, como pepsina e tripsina. Do mesmo modo, mananases de $C$. byssicola são enzimas adequadas para hidrólise de extratos de café devido à sua maior atividade em $\mathrm{pH}$ 5,0 (CHAUAN, et al., 2012).

\subsubsection{Termoestabilidade}

A estabilidade é um fator chave para a utilização de enzimas em processos industriais, seu estudo pode fornecer informações sobre estrutura e função de enzimas. Além do mais, a estabilidade enzimática sobre longos períodos é uma importante característica para seleção de mananases (GUMMADI e PANDA, 2003). A fim de avaliar a meia vida de mananase contida no EBC e na fração semi-purificada (ManQFF), foram realizados ensaios de termoestabilidade como mostrado na figura 18 e 19 . A meia vida de uma enzima pode ser definida como o tempo necessário para que a atividade enzimática decresça à metade da sua atividade original (GRIFFIN, et al., 1984 apud SCIUTO, 2015). A mananase presente no extrato bruto concentrado e na fração semi-purificada (ManQFF), foi incubada em três temperaturas distintas: 40, 50, e $55^{\circ} \mathrm{C}$. Pode-se observar que, quando o EBC foi incubado a uma temperatura de $40{ }^{\circ} \mathrm{C}$, a atividade de mananase permaneceu estável após 96 horas de incubação. No tempo de 192 horas (8 dias) a atividade de mananase atingiu 2,90 UI/mL, chegando próximo a metade da atividade máxima $(2,40 \mathrm{UI} / \mathrm{mL})$. Quando incubada à $50^{\circ} \mathrm{C}$, a meia vida da enzima foi de apenas 3 h de incubação. Em contrapartida, a mananase do EBC atingiu atividade inferior a 50\%, em apenas $30 \mathrm{~min}$, quando incubada a $55^{\circ} \mathrm{C}$.

Diferente do EBC, a fração semi-purificada (ManQFF) apresentou níveis inferiores de estabilidade (fig. 18). A enzima apresentou meia vida durante o tempo de 50 min quando incubada à $40^{\circ} \mathrm{C}$. No entanto, em temperaturas maiores $\left(50\right.$ e $\left.55^{\circ} \mathrm{C}\right) \mathrm{a}$ 
ManQFF atingiu sua meia vida em menos de 15 min. De acordo com Lu et al., (2014) a baixa estabilidade da enzima pode ser explicada pela ausência do substrato, uma vez que ele pode estabilizar a enzima e consequentemente, resultar em uma maior atividade em altas temperaturas. Além do mais, experimentos realizados por Srivastava, et al., (2016) mostraram que o aumento da termoestabilidade de enzimas pode ser explicado pela ligação de íons no sítio catalítico da enzima e pela presença de CBMs. Os CBMs podem fornecer proteção ao domínio catalítico e sua ausência pode desencadear diminuição na termoestabilidade de algumas enzimas.

A produção de mananases com características inferiores às mananases produzidas por $C$. byssicola são relatados em diversos trabalhos. Wang e colaboradores (2015) produziram uma $\beta$-mananase de Arabidopsis thaliana que manteve 90-100\% da sua atividade por 4 horas quando incubada a $35^{\circ} \mathrm{C}$, no entanto, quando incubada a $45^{\circ} \mathrm{C}$ a atividade residual alcançou 45\% depois de 4 horas de incubação. Zhang, et al. (2015) caracterizaram uma mananase isolada de Grus nigricolli que apresentou meia vida de 60 min a $37^{\circ} \mathrm{C}$, além disto, a enzima perdeu sua atividade após a incubação de 2 min a 50 ${ }^{\circ} \mathrm{C}$. Zhou, et al. (2012) identificaram uma mananase produzida por cepas Shingomonas que foram estáveis por mais de 60 min a $35^{\circ} \mathrm{C}$, no entanto, a meia vida da enzima foi de aproximadamente 15 min quando incubada a $45^{\circ} \mathrm{C}$. Song, et al. (2008) produziram uma mananase em que a meia vida era inferior a 10 min quando incubada a uma temperatura de $45^{\circ} \mathrm{C}$. 

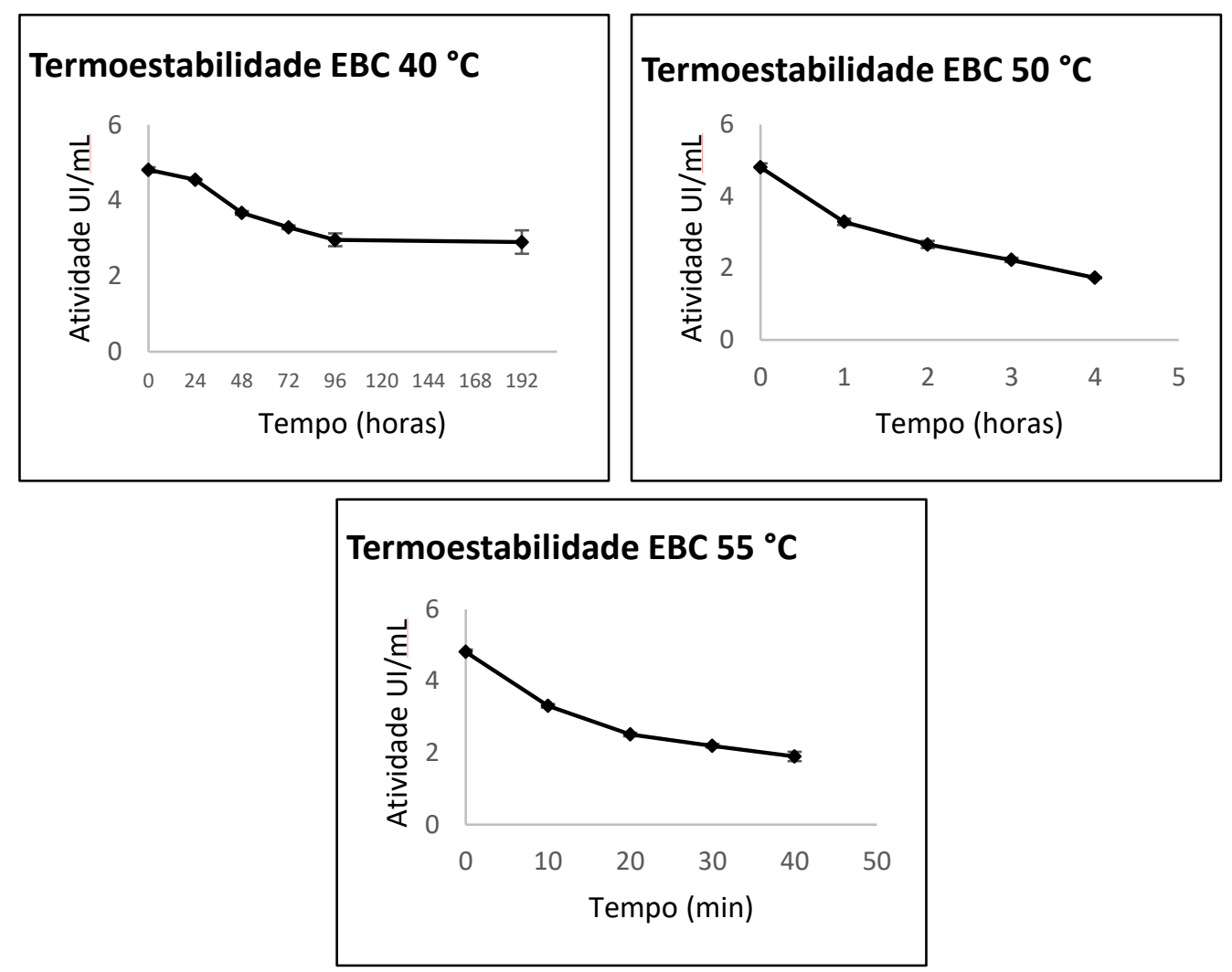

Figura 18. Determinação da termoestabilidade de mananase do extrato bruto concentrado a 40,50 e 55 ${ }^{\circ} \mathrm{C}$.
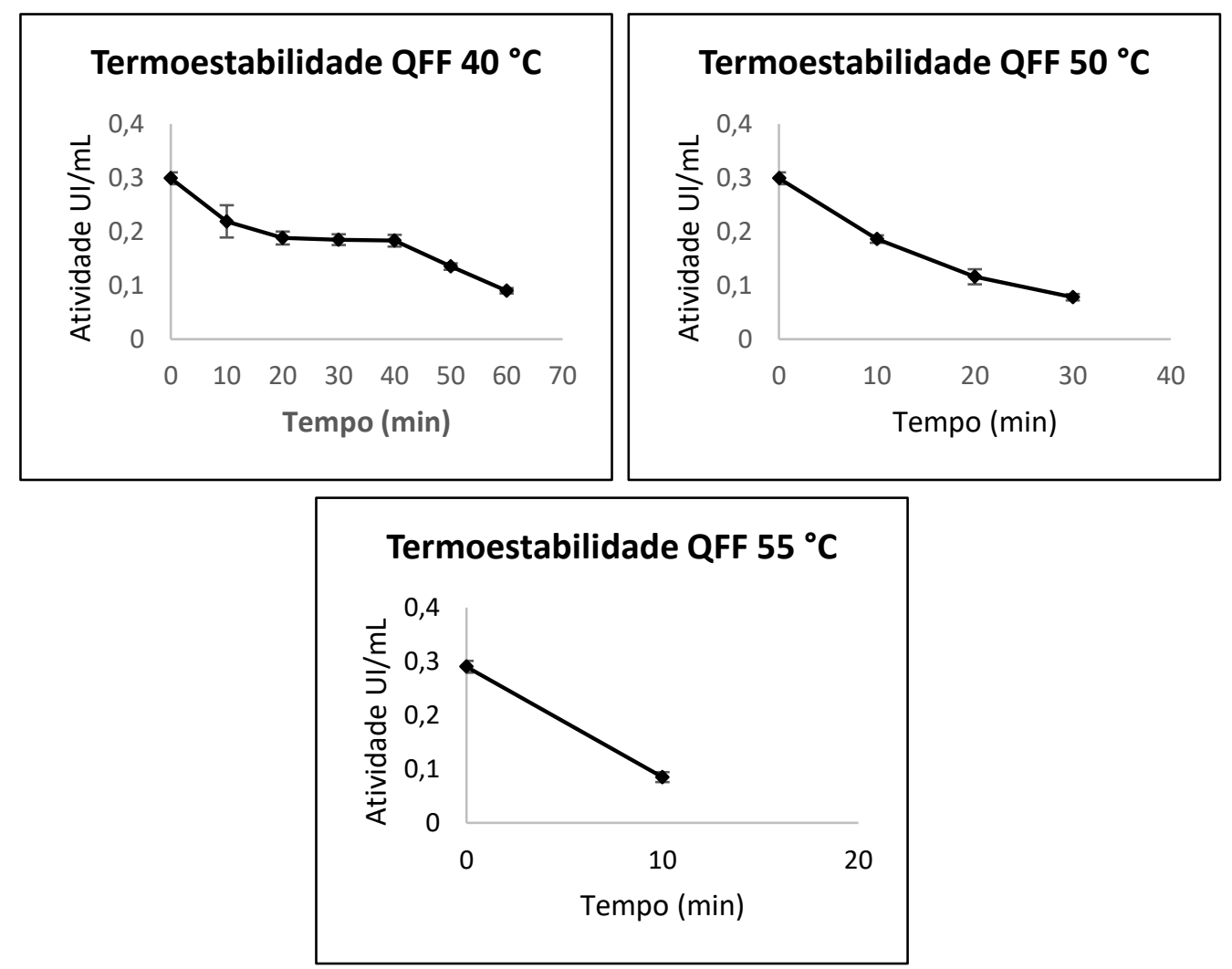

Figura 19. Determinação da termoestabilidade de mananase da fração semi-purificada (ManQFF) a 40, 50 e $55^{\circ} \mathrm{C}$. 


\subsubsection{Efeito de íons e EDTA na atividade de mananase}

$\mathrm{Na}$ natureza, enzimas que degradam a biomassa lignocelulósica estão, provavelmente, em contato com diversos íons metálicos. Ademais, níveis significantes desses compostos podem ser encontrados em sistemas enzimáticos industriais para conversão da biomassa (TEJIRIAN e XU, 2010).

Algumas enzimas necessitam, além de seus resíduos de aminoácidos, componentes químicos adicionais como os cofatores. Os cofatores são íons inorgânicos que podem estar firmemente ligados às proteínas aumentando sua atividade. A ativação e inibição de íons e compostos químicos na atividade de enzimas constitui uma ferramenta de grande importância para caracterização química e o entendimento do modo de ação das enzimas (JARAMILLO, 2014). A tabela 4, apresenta o efeito de íons e EDTA na atividade de mananase. A atividade de mananase do EBC foi parcialmente inibida na presença do íon (concentração final de $1 \mathrm{mM}$ ), $\mathrm{Co}^{2+}$. Os íons $\mathrm{Ag}^{+}, \mathrm{Co}^{2+}, \mathrm{Ca}^{2+}, \mathrm{Cu}^{2+}, \mathrm{Fe}^{2+}$, $\mathrm{Fe}^{3+}, \mathrm{K}^{+}, \mathrm{Mg}^{2+}, \mathrm{Mg}^{3+}, \mathrm{Zn}^{2+}$ e o agente quelante EDTA (nas concentrações de 1 e $10 \mathrm{mM}$ ) inibiram de forma mais significativa a atividade da enzima. No entanto, o íon $\mathrm{Co}^{2+}$, aumentou (5\%) a atividade de mananase do EBC (na concentração de $10 \mathrm{mM}$ ). Por outro lado, o íon $\mathrm{Co}^{2+}$ ativou em $15 \%$ e $35 \%$ a atividade da ManQFF, quando incubada nas concentrações de $1 \mathrm{mM}$ e $10 \mathrm{mM}$, respectivamente. Como mostrado na tabela, nenhum aumento considerável de atividade de mananase foi observado quando os íons foram incubados na concentração final de $1 \mathrm{mM}$.

Quando as mananases foram incubadas em concentrações maiores de íons (10 $\mathrm{mM}$ ) apenas o íon $\mathrm{Co}^{2+}$ foi capaz de aumentar atividade da mananase do EBC e da enzima ManQFF. Os íons $\mathrm{Fe}^{2+}, \mathrm{Fe}^{3+}, \mathrm{Zn}^{2+}$, e o quelante EDTA inibiram fortemente a atividade do EBC e da Fração semi-purificada. Assim como mostrado nesse trabalho, a presença de $\mathrm{Fe}^{3+}, \mathrm{Zn}^{2+}, \mathrm{Cu}^{2+}$ e outros íon afetaram fortemente a atividade de mananase produzida por Biospora sp. (LUO, et al., 2009). Do mesmo modo, Lu et al. (2013) relataram que a presença dos íons $\mathrm{Fe}^{3+}, \mathrm{Zn}^{2+}, \mathrm{Cu}^{2+}$ inibiram parcialmente a atividade de mananases derivadas de Aspergillus nidulans. Yang W. e colaboradores (2015) evidenciaram qua a mananase do fungo Arabidopisis thaliana diminuiu sua atividade na presença de $\mathrm{Fe}^{3+}$. LIU, et al. (2015) detectaram uma moderada inibição dos íons $\mathrm{Fe}^{3+}$ e $\mathrm{Cu}^{2+}$ na atividade de mananase de Bacillus subtilis. Chen, et al. (2007) produziram uma mananase de Aspergillus sulphureus que sofreu forte inibição quando incubada com o íon $\mathrm{Cu}^{2+}$. 
TABELA 4- EFEITO DE ÍONS E EDTA NA ATIVIDADE DE MANANASE

\begin{tabular}{|c|c|c|c|c|}
\hline \multicolumn{5}{|c|}{ Atividade relativa (\%) } \\
\hline & \multicolumn{2}{|c|}{$1 \mathrm{mM}$} & \multicolumn{2}{|c|}{$10 \mathrm{mM}$} \\
\hline & EBC & ManQFF & EBC & ManQFF \\
\hline Controle & $100 \pm 3,1$ & $100 \pm 2,8$ & $100 \pm 3,1$ & $100 \pm 2,8$ \\
\hline $\mathrm{AgNO}_{3}$ & $66,99991 \pm 5,5$ & $48,40705 \pm 2,3$ & $35,83655 \pm 3,9$ & $58,78083 \pm 3,9$ \\
\hline $\mathrm{CaCl}_{2}$ & $77,63413 \pm 1,4$ & $75,67223 \pm 3,8$ & $99,33099 \pm 3,6$ & $53,72015 \pm 2,4$ \\
\hline $\mathrm{CoCl}_{2}$ & $93,04312 \pm 1,7$ & $105,0181 \pm 3,6$ & $115,6208 \pm 3,3$ & $135,0943 \pm 2,8$ \\
\hline $\mathrm{CuSO}_{4}$ & $69,93433 \pm 4,0$ & $48,08737 \pm 2,5$ & $32,79544 \pm 2,9$ & $43,88056 \pm 5,6$ \\
\hline $\mathrm{FeCl}_{3}$ & $86,42016 \pm 3,2$ & $29,5087 \pm 1,2$ & $8,549558 \pm 2,6$ & $36,11704 \pm 2,7$ \\
\hline $\mathrm{FeSO}_{4}$ & $82,49805 \pm 2,6$ & $28,84165 \pm 2,3$ & $3,294548 \pm 3,7$ & $28,84165 \pm 1,8$ \\
\hline $\mathrm{KCl}$ & $80,34959 \pm 5,9$ & $52,22327 \pm 3,4$ & $35,83655 \pm 1,3$ & $78,94512 \pm 1,6$ \\
\hline $\mathrm{MgCl}_{2}$ & $78,36473 \pm 4,9$ & $86,76454 \pm 1,1$ & $99,33099 \pm 2,9$ & $86,0856 \pm 4,5$ \\
\hline $\mathrm{MgSO}_{4}$ & $84,93036 \pm 3,5$ & $87,88793 \pm 2,8$ & $79,98921 \pm 3,4$ & $63,16738 \pm 5,3$ \\
\hline $\mathrm{ZnSO}_{4}$ & $87,08977 \pm 5,4$ & $29,22386 \pm 4,7$ & $8,549558 \pm 2,1$ & $30,26929 \pm 1,6$ \\
\hline EDTA & $84,4051 \pm 5,3$ & $29,57487 \pm 2,6$ & $3,294548 \pm 1,3$ & $54,63747 \pm 1,3$ \\
\hline
\end{tabular}

Como parte da caracterização de enzimas, íons metais divalentes, $\left(\mathrm{Mg}^{2+}, \mathrm{Ca}^{2+}\right.$, $\left.\mathrm{Mn}^{2+}, \mathrm{Fe}^{2+}, \mathrm{Co}^{2+}, \mathrm{Ni}^{2+}\right)$ trivalentes, $\left(\mathrm{Fe}^{3+}\right)$ e monovalentes $\left(\mathrm{Na}^{+}, \mathrm{K}^{+}\right)$são frequentemente testados para o seu efeito na atividade enzimática (TEJIRIAN e XU, 2010). Assim como o íon $\mathrm{Co}^{2+}$ aumentou a atividade de mananase de $C$. byssicola, a tabela 5 mostra que para outros microrganismos esse íon atua como ativador de diferentes tipos de mananases, estando raramente agindo como inibidor dessas enzimas. No entanto, ao analisarmos a tabela podemos perceber que o íon $\mathrm{Cu}^{2+}$ atua como inibidor para a maioria das enzimas apresentadas. De acordo com Tijirian e Xu (2010) as diferenças encontradas em relação a ativação e inibição de enzimas podem ser explicadas pela interação dos íons com os resíduos de aminoácidos das proteínas, podendo exercer ou não inibição. 
TABELA 5- EFEITO DE ÍONS E EDTA NA ATIVIDADE DE MANANASES DE DIVERSOS MICRORGANISMOS.

\begin{tabular}{|c|c|c|c|}
\hline [] $\mathrm{mM}$ & Ativador & Inibidor & Referência \\
\hline 1 & $\mathrm{Ca}^{2+}$ & $\mathrm{Ag}^{2+}, \mathrm{Cu}^{2+}, \mathrm{Mg}^{2+}$ & Naganagouda, et al., 2009. \\
\hline 5 & $\mathrm{NaCl}, \mathrm{KCl}, \mathrm{MgCl}$ & $\mathrm{FeCl}_{2}$ & Kumagai, et al., 2011. \\
\hline & - & $\mathrm{CaCl}_{2}, \mathrm{CuSO}_{4}, \mathrm{FeSO}_{4}$ & Chantorn, et al., 2013. \\
\hline 1 & & $\mathrm{CoCl}_{2}$ EDTA, & \\
\hline 1 & $\mathrm{Co}^{2+}, \mathrm{Cu}^{2+}, \mathrm{Mg}^{2+}$ & $\mathrm{Fe}^{3+}, \mathrm{Fe}^{2+}$ & Chauhan, et al., 2014. \\
\hline 1 & $\mathrm{Co}^{+}$ & $\mathrm{Cu}^{2+}, \mathrm{Fe}^{2+}$, EDTA & Piwpankaew, et al., 2014. \\
\hline 1 & $\mathrm{Zn}^{2+}, \mathrm{K}^{+}, \mathrm{Na}^{+}$ & EDTA & Chai, et al., 2015 \\
\hline 5 & $\mathrm{Zn}^{2+}, \mathrm{K}^{+}, \mathrm{Na}^{+}$ & EDTA & Chai, et al., 2015 \\
\hline 1 & $\mathrm{Co}^{2+}, \mathrm{Fe}^{3+}$ & $\mathrm{Ca}^{2+}$ & Srivastava, et al., 2015. \\
\hline 25 & $\mathrm{KCl}, \mathrm{CoCl}, \mathrm{MgCl}$ & $\mathrm{FeCl}_{3}$, & Ge, et al., 2016. \\
\hline 1 & $\mathrm{Co}^{2+}, \mathrm{K}^{+}, \mathrm{Na}^{+}$ & $\mathrm{Cu}^{2+}$, EDTA & Pradeep, et al., 2016. \\
\hline 1 & $\mathrm{Co}^{2+}, \mathrm{Ag}^{+}, \mathrm{EDTA}, \mathrm{Ca}^{2+}$ & $\mathrm{Zn}^{2+}, \mathrm{Na}^{+}$ & Wang, et al., 2016. \\
\hline 5 & $\mathrm{Co}^{2+}, \mathrm{Zn}^{2+}$ & $\begin{array}{c}\mathrm{Fe}^{3+}, \mathrm{Na}^{+}, \mathrm{EDTA}, \mathrm{Ag}^{+} \\
\mathrm{Cu}^{2+}\end{array}$ & Wang, et al., 2016. \\
\hline 1 & $\mathrm{Ca}^{2+}, \mathrm{Mg}^{2+}, \mathrm{Zn}^{2+}$ & $\mathrm{Cu}^{2+}$ & Yang et al., 2016. \\
\hline 10 & $\mathrm{Ca}^{2+}, \mathrm{Mg}^{2+}, \mathrm{Co}^{2+}$ & $\mathrm{Cu}^{2+}$ & Yang et al., 2016. \\
\hline
\end{tabular}

5.4.4 Efeito de compostos fenólicos na atividade de mananase

Os compontos fenólicos presentes em plantas podem inibir a hidrólise enzimática em concentrações que variam entre $\mu \mathrm{M}$ a mM (XIMENES, et al., 2010). A tabela 6 mostra a influência dos compostos fenólicos na atividade de mananase do EBC e na fração semi-purificada (ManQFF) quando incubados em uma concentração final de $1 \mathrm{mg} / \mathrm{mL}$. Para as duas amostras, os resultados mostraram-se negativos, não havendo aumento da atividade de mananase. O ácido-p-coumário e o ácido cinânimo inibiram fortemente a atividade do EBC (com uma redução de 42 e $44 \%$ da atividade de mananase) e da ManQFF (reduzindo cerca de 99 e $87 \%$ da atividade de mananase). Além do mais a 
atividade da ManQFF apresentou uma redução de 69\% quando incubado com o ácido ferúlico.

Poucos estudos tem avaliado o efeito de compostos fenólicos na atividade de mananases, contudo, estudos realizados por Infante et al. (2015) e Gomes (2014) mostraram que os compostos fenólicos podem aumentar a atividade de mananases de diferentes microrganismos, o que não foi observado nesse trabalho. Infante et al. (2015) mostraram que a mananase semi-purificada de A. foetidus foi inibida (7\%) por ácido cinâmico, contudo a incubação com ácido ferúlico proprocionou um aumento de $51 \%$ da atividade de mananase (Man58). Ademais, os outros compostos fenólicos não influenciaram a atividade de mananase. Da mesma forma, Gomes (2014) mostrou que o ácido cinâmico inibiu (10\%) a atividade de mananase, enquanto que o ácido ferúlico ativou a enzima em quase $150 \%$. Outros compostos como o ácido p-coumárico e o ácido 4-hidroxi-benzóico aumentaram a atividade de mananase em 25\% e 23\%, respectivamente.

O efeito de compontos fenólicos na atividade de outras enzimas hemicelulósicas, como as xilanases, tem ganhado maior atenção. Moreira e Ferreira Filho (2016) mostraram que as xilanases podem aumentar sua atividade quando incubadas com vanilina. Como também podem ser resistentes a presença de ácidos como: p-coumárico, ferúlico, tânico e 4-hidróxi-benzóico. Contudo, xilanases de alguns microrganismos são inibidas por ácido cinâmico, ácido p-cumarico e o ácido 4-hidroxi-benzóico. O efeito dos compostos fenólicos sobre as funções biológicas de proteínas e estruturas secundárias e terciárias, assim como parâmetros termodinâmicos tem sido estudado para maior compreensão do modo de ação dessas enzimas (MOREIRA e FERREIRA FILHO, 2016). 
TABELA 6- EFEITO DE COMPOSTOS FENÓLICOS NA ATIVIDADE DE MANANASE.

\begin{tabular}{c|cc}
\hline \multicolumn{3}{c}{ Atividade Relativa (\%) } \\
\hline Controle & EBC & ManQFF \\
Vanilina & $100 \pm 2,7$ & $100 \pm 3,1$ \\
Ácido tânico & $78,15273 \pm 1,1$ & $50,82301 \pm 2,9$ \\
Ácido p-coumárico & $68,66232 \pm 3,6$ & $59,9312 \pm 2,5$ \\
Ácido cinâmico & $58,2603 \pm 4,1$ & $0,99091 \pm 3,3$ \\
Ácido ferúlico & $80,22051 \pm 2,0$ & $31,62134 \pm 1,9$ \\
Ácido 4-hidróxi-benzóico & $61,20603 \pm 1,8$ & $47,78536 \pm 4,3$
\end{tabular}

\subsubsection{Parâmetros cinéticos}

Afim de avaliar a afinidade da enzima pelo substrato e a velocidade da reação, foram determinados os parâmetros cinéticos de mananase do EBC e da fração ManQFF. O EBC apresentou um $\mathrm{K}_{\mathrm{M}}$ aparente de 12,73 $\pm 1,97 \mathrm{mg} / \mathrm{mL}$ e $\mathrm{V}_{\text {máx }}$ de 7,65 \pm 0,52 UI/mL, enquanto a fração semi-purificada exibiu $K_{M}$ de $8,53 \pm 0,31 \mathrm{mg} / \mathrm{mL}$ e $\mathrm{V}_{\text {máx }}$ de $0,255 \pm$ 0,0033. Zhou, et al. (2015) descreveram um $\mathrm{K}_{\mathrm{M}}$ de $9,5 \pm 0,5 \mathrm{mg} / \mathrm{mL}$ para enzima recombinante Man1312. Da mesma forma, Zhou et al. (2016) produziram mananases (Man26 e Man1606) com valores de $\mathrm{K}_{\mathrm{M}}$ de 9,2 $\pm 0,1$ e 8,5 $\pm 0,1$.

Srivastava, et al. (2015) purificaram uma mananase com $\mathrm{K}_{\mathrm{M}}$ e $\mathrm{V}_{\text {máx }}$ de 6,5 $\mathrm{mg} / \mathrm{mL}$ e $5000 \mathrm{UI} / \mathrm{mL} / \mathrm{min}$, respectivamente. Wang et al. (2014) caracterizaram duas mananases recombinantes com diferentes níveis de glicosilação mostrando $K_{M}$ e $V_{\text {máx }}$ de $1,90 \mathrm{mg} / \mathrm{mL}$ e 3,092 U/min/mg para Man5A1, e 2,19 mg/mL e 3,501 U/min/mg para Man5A2. Zheng, et al. (2016) obtiveram mananases que apresentaram $K_{M}$ e $V_{\text {máx }}$ de: 11 $\mathrm{mg} / \mathrm{mL}$ e $3333,33 \mu \mathrm{mol} / \mathrm{min}$ (32 ${ }^{\mathrm{a}}$-ManAR2) e $4 \mathrm{mg} / \mathrm{mL}$ e $5000 \mu \mathrm{mol} / \mathrm{min}$ (22b-ManAR2).

\subsection{HIDRÓLISE ENZIMÁTICA}

A figura 20 mostra a liberação de açúcares redutores totais pela hidrólise enzimática da manana e casca de soja utilizando a amostra enzimática do EBC. Como 
podemos observar, a quantidade de açúcares redutores resultantes da degradação da manana aumentou até oito horas de incubação, permanecendo estáveis por 96 horas. Em contrapartida, os açúcares liberados durante a hidrólise da casca de soja aumentaram gradualmente até o tempo de 24 horas, mantendo-se estáveis entre o período de 24-72 horas, produzindo maiores quantidades de açúcares redutores após 72 horas. A liberação de açúcares redutores durante a hidrólise da manana $1 \%$ até o tempo de 72 horas foi maior do que a casca de soja. Essa diferença, pode ser explicada pela composição química dos substratos utilizados, uma vez que diferente da manana (derivada de goma de alfarroba) a casca de soja apresenta em sua composição química (tabela 1) pectina, celulose, hemicelulose e lignina, componentes responsáveis por aumentar a recalcitrância de sua estrutura.

A hidrólise enzimática de produtos com alto teor de manana, e a quantificação dos açúcares redutores totais tem sido demostrada em diversos trabalhos. Blibech et al. (2011) mostraram que a hidrólise de goma de alfarroba $(0,5 \%)$ por mananases de Penicillium occitanis liberou açúcares redutores até o tempo de 6 horas. Nesse caso, a enzima semi-purificada foi incubada por 10 horas à $70^{\circ} \mathrm{C} \mathrm{em} \mathrm{pH} \mathrm{7,0.} \mathrm{Chantorn,} \mathrm{et} \mathrm{al.}$ (2013) mostraram que a hidrólise de diferentes resíduos agroindustriais produziu grandes quantidades de açúcares redutores quando o extrato bruto, contendo mananases, foi incubado por 48 horas à $60^{\circ} \mathrm{C} \mathrm{e} \mathrm{pH} \mathrm{4,0.} \mathrm{Os} \mathrm{valores} \mathrm{de} \mathrm{açúcares} \mathrm{redutores} \mathrm{foram:} \mathrm{7,517.82}$ $\mu \mathrm{g} / \mathrm{mL}$ (farelo de copra), 3,827.64 $\mu \mathrm{g} / \mathrm{mL}$ (bagaço), 3,309.49 $\mu \mathrm{g} / \mathrm{mL}$ (casca de batata) e 2,325 $\mu \mathrm{g} / \mathrm{mL}$ (farelo de soja). Os trabalhos citados anteriormente, corroboram com os dados obtidos nesse trabalho, mostrando que resíduos agroindustriais liberam maiores quantidades de açúcares redutores em tempos maiores de hidrólise. 


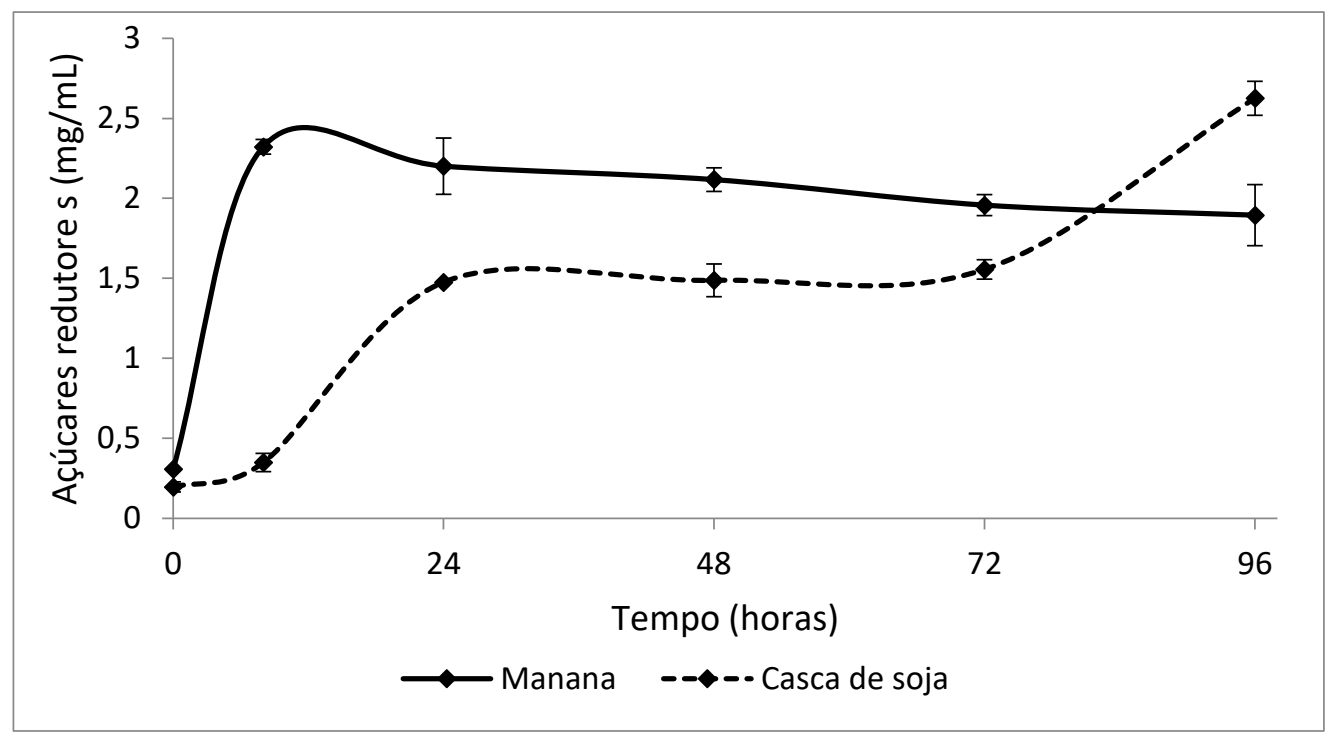

Figura 20. Quantificação de açúcares redutores totais por DNS obtidos pela hidrólise da manana $1 \%$ e casca de soja pelas enzimas do EBC.

A detecção de mano-oligossacarídeos é exibida na figura 21. De acordo com o gráfico, os produtos liberados durante a hidrólise da casca de soja (21-A) foram: manose, manobiose, manotriose e manopentose. Oligossacarídeos como manotetraose e manohexaose não foram identificados. Contudo, na degradação de manana 1\% (21-B), além dos produtos encontrados anteriormente, foi possível identificar a presença de manotetraose e manohexaose.

Quando comparamos a figura 20 e 21, podemos perceber que o perfil de açúcares redutores gerados durante a hidrólise da casca de soja aumentou gradualmente, atingindo seu pico máximo no tempo de 96 horas. Da mesma forma, na detecção de manooligossacarídeos (21-A) a quantidade de manose aumentou ao longo do tempo. No entanto, quando analisamos a hidrólise enzimática da manana, os açúcares redutores aumentaram até 8 horas, contudo na detecção de mano-oligossacarídeos (21-B) há um aumento de manose ao longo do tempo, apresentando um perfil diferente da hidrólise enzimática. Essa diferença pode ser explicada pela presença de mano-oligossacarídeos com grau de polimerização maior que a manohexaose, fazendo com que haja uma maior detecção de açúcares redutores pelo método de DNS. No entanto, nas análises de HPLC esses açúcares não são detectados, pois a curva padrão não identifica mano-oligômeros com grau de polimerização maior do que sete.

Uma característica importante apresentada na hidrólise dos substratos é a grande quantidade de manose gerada. A presença de manose como produto de hidrólise da 
manana $1 \%$ e casca de soja, sugere que as enzimas do EBC são compostas, principalmente, por $\beta$-manosidases (exo mananases), enzimas que degradam manooligossacarídeos, gerando manose como produto final.

A produção de manose tem despertado grande interesse como pré-biótico da microbiota intestinal (YAMABHAI et al., 2014). Quando comparado com outros trabalhos, as enzimas produzidas por $C$. byssicola mostraram-se mais eficientes para a produção de manose. Soni et al. (2016b) realizaram a hidrólise de goma de alfarroba (LBG), goma de konjac (KG) e goma guar (GG), por mananase produzidas por A. levis. Os autores descreveram que a hidrólise de LBG e GG gerou poucas quantidades de manobiose e manose, e porcentagens maiores de oligossacarídeos. Contudo, na hidrólise de KG não houve detecção de manose e manobiose, sendo detectados apenas oligossacarídeos. A hidrólise do substrato não liberou, esse resultado pode ser explicado pela ausência de uma exo-mananase, responsável por clivar mano-oligossacarídeos gerando como produto manose.

Dhawan, et al. (2015) realizaram a hidrólise de farelo de trigo, LBG, GG e KG, utilizando enzimas produzidas por Paenibacillus thiaminolyticus. A hidrólise de LBG gerou manobiose, manotriose e manotetraose. KG e GG foram degradados à manobiose, manotriose e manotetraose, por fim, a degradação do farelo de trigo gerou como produto todos os demais mano-oligossarídeos, incluindo manose e manohexaose. No entanto, pouco quantidade de manose foi detectada, indicando que as enzimas do extrato bruto contêm grandes quantidades de endo-mananases em detrimento de $\beta$-manosidases.

Em trabalho realizado por Harnpicharnchai et al. (2016), mananases de A. niger foram utilizadas em ensaio de hidrólise enzimática de farelo de amêndoa de palma (PKM) e farelo de copra (CM). Ambos os substratos foram degradados à manose, manobiose e manotriose, contudo, maiores quantidades de manose foram produzidas pela hidrólise de PKM.

Pangsri et al. (2015) produziram uma mananase de Bacillus circulans que degradou LBG, CM e KG. LBG foi hidrolisado à manobiose, manotriose, manotetraose, manopentose e manohexaose. Contudo, $\mathrm{CM}$ e $\mathrm{KG}$ foram clivados em manotriose, manotetraose, manopentose e manohexaose. 


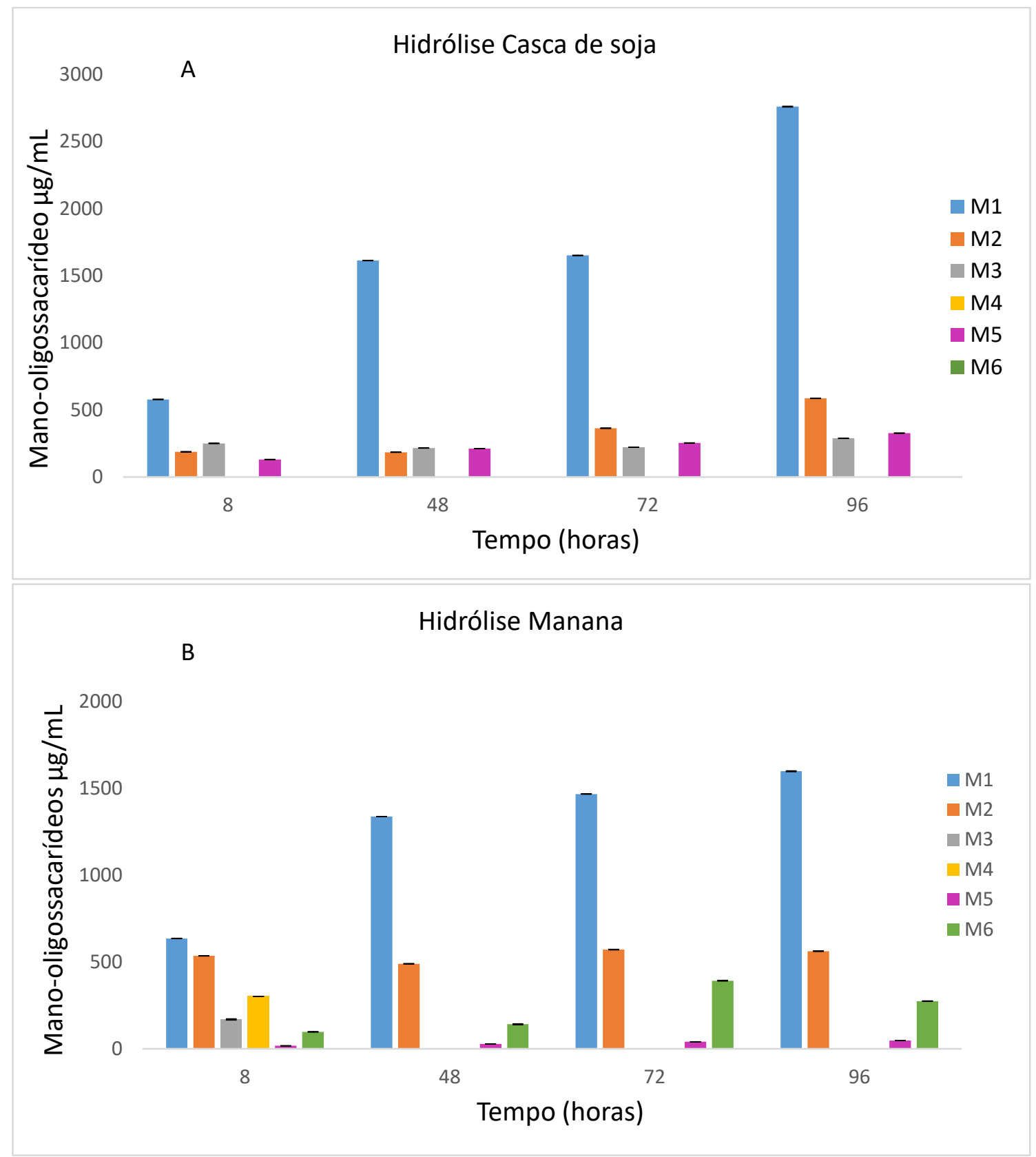

Figura 21. Identificação de mano-oligossacarídeos produzidos durante a hidrólise da casca de soja (A) e da manana $1 \%$ (B) por enzimas presentes no EBC.

\section{CONCLUSÕES}

Pouco se sabe sobre a capacidade de $C$. byssicola em produzir enzimas que sejam capazes de desconstruir a parede celular vegetal, uma vez que pesquisas acerca de tal fungo tem levado em consideração apenas suas características como agente de controle biológico e como fungo produtor de quitinases. $\mathrm{O}$ estudo de algumas propriedades de $C$. byssicola mostrou que o isolado foi capaz de crescer em meio submerso, contendo casca 
de soja como fonte de carbono, produzindo proteoformas de mananases com tamanhos que variam entre $36,6-53 \mathrm{kDa}$.

A utilização da casca de soja como matéria prima para o crescimento de fungos ainda é pouco explorada. Devido ao alto teor de manana encontrado em sua estrutura, esse substrato mostrou-se ideal para indução de mananases. Além do mais, a pequena quantidade de lignina encontrada na casca de soja torna esse substrato menos recalcitrante, não necessitando de pré-tratamentos com a utilização de ácidos ou solventes orgânicos.

A caracterização do EBC e da fração ManQFF, mostrou que essas amostras enzimáticas foram ativas em $\mathrm{pH}$ e temperatura determinantes para que essas enzimas sejam utilizadas em diversas aplicações industriais, incluindo aditivos de ração e hidrólise de extratos de café.

Outra característica importante de mananases do EBC e da fração semipurificada ManQFF, foi a grande produção de manose gerada pela hidrólise da casca de soja e manana 1\%. Esses açúcares têm despertado interesse em indústrias farmacêuticas e de alimentos, devido ao favorecimento do crescimento de microrganismos benéficos no intestino.

\section{PERSPECTIVAS}

Dar continuidade ao processo de purificação de isoformas de mananases. Com intuito de clonar e expressar os genes que codificam essas enzimas. As sequências de mananases serão identificadas por espectrometria de massas. Ademais, mananases resultantes da expressão heteróloga serão utilizadas em ensaios de hidrólise enzimática, para a detecção dos produtos de hidrólise gerados pela enzima pura. Será realizado também um estudo detalhado do efeito de mananases na redução da viscosidade de extratos de café e como aditivos de ração. 


\section{REFERÊNCIAS}

ABRAMSON, M.; SHOSEYOV, O.; SHANI, Z. Plant cell wall reconstruction toward improvement lignocellulosic production and processability. Plant Science, v. 178, n. 2, p. 5, p. 61-72, 2013.

ACKER, R. V. et al. Lignin biosynthesis perturbations affect secondary cell wall composition and saccharification yield in Arabidopsis thaliana. Biotechnology for Biofuels, v. 6, n. 1, p. 117, 2013.

ADESinA, F. C.; OlubOYEDE, O. A.; ONILUdE, A. Production, purification and characterization of $\beta$-mannanase by Aspergillus niger through solid state fermentation (SSF) of Gmelia arbórea shavings. African Journal of Microbiology Research, v. 7, n. 4, p. 282289, 2013.

ADIGUZEL, A; NADAROGLU, H.; ADIGUZEL, G. Purification and characterization of $\beta$ mannanase from Bacillus pumilus (M27) and its application in some fruit juices. Journal of Food Scienci and Technology, v. 52, n. 8, 2014.

ADIGUZEL, G. et al. Purification and characterization of a thermostable endo-beta-1,4 mannanase from Weissella viridescens LB37 and its application in fruit juice clarification. Eropean Food Research and Technology, v. 242, n. 5, p. 769-776, 2015.

ÁLVAREZ, C.; REYES SOSA, F. M.; DÍEZ, B. Enzymatic hydrolysis of biomass from wood. Microbial biotechnology, v. 9, n. 2, p. 149-156, 2015.

ALVINDIA, D. G.; NATSUAKI, K. T. Evaluation of fungal epiphytes isolated from banana fruit surfaces for biocontrol of crown rot disease. Crop protection, v. 27, n. 8, p.1200-1207, 2008.

ANDRADE, A. P.; QUADROS, D. G.; Composição bromatológica da casca de soja amonizada com uréia. Revista de Biologia e Ciências da Terra, v. 11, n. 1, p. 38-46, 2011.

ANDREAUS, J.; FERREIRA FILHO, E. X.; BON, E. P. S. Biotechnology of holocelulosedegrading enzymes. In: HOU, C. T.; SHAW, J. F. (Eds.) Biocatalysis and Bioenergy. New Jersey: Wiley, 2008. Chapter 11, p. 197-229.

ARANTES, V.; SADDLER, J. N. Acess to cellulose limts the efficiency of enzymatic hydrolysis: the role of amorphogenesis. Biotecnhology for Biofuels, v. 3, n. 4, p. 1-11, 2010.

ARO, N.; PAKULA, T.; PENTTILÃ. Transcriptional regulation of plant cell wall degradation by filamentous fungi. FEMS Microbiology Reviews, v. 29, n. 4, p. 719-739, 2005. 
AZEVEDO, M. A. B. Diferentes processos de branqueamento da celulose e seus efeitos nas propriedades físicas e cristalinidade. 2011. 158 f. Tese (Doutorado em Química) Universidade Federal de Minas Gerais) - UFMG, Belo Horizonte, 2011.

BENECH, R. O. et al. Recombinant expression, characterization, and pulp prebleaching

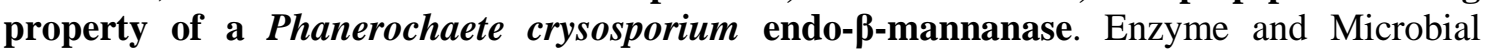
Technology, v. 41, n.6-7, p. 740-747, 2007.

BLIBECH, M. et al. Production of manno-oligossacharides from locust bean gum using immobilized penicillium occitanis mannanase. Journal of Molecular and Catalysis B Enzymatic, v. 73, n. 1, p. 11-115, 2011.

BLUM, H.; BEIER, H.; GROSS, H. J. Improved silver staining of plant-proteins, RNA and DNA in polyacrylamide gels. Electrophoresis, v. 8, p.93-99, 1987.

BOERJAN, W.; RALPH, J.; BAUCHER, M. Lignin biosynthesis. Annual review of Plant of Biology, v. 54, p. 519-546, 2003.

BRADFORD, M. M. A rapid and sensitive method for the quantitation of microgram quantities of protein utilizing the principle of protein-dye binding. Analytical Biochemistry, v. 72 , n. 1-2, p. 248-254, 1976.

BRÁS, F. N.; FERNANDES, P. A.; RAMOS, M. J. Docking and molecular dynamics studies on stereoselectivity in the enzymatic synthesis of carbohydrates. Theoretical Chemistry accounts, v. 122, n. 5, p. 122-283, 2009.

BRIJAWANI, K.; OBEROI, H. S.; VADLANI, P. V. Production of a cellulolytic enzyme system in mixed-culture solid-state fermentation of soybean hulls supplemented with wheat bran. Process Biochemistry, v. 45, n. 1, p. 120-128, 2010.

CAFFALL, K. H.; MOHNEN, D. The structure, function, and biosynthesis of plant cell wall pectin polysaccharides. Carbohydrate, v. 344, n. 14, p. 1879-900, 2009.

CASSALES, A. et al. Optimization of soybean hull acid hydrolysis and its characterization as a potential substrate for bioprocessing. Biomass and Bioenergy, v. 35, n. 11, p. 4675-4683, 2011.

CARVALHO, C. O. Comparação entre métodos de extração de óleo de Mauritia flexuosa L.f. (arecaceae - buriti) para o uso sustentável na reserva de desenvolvimento tupé: rendimento e atividade antimicrobiana. 2011. $110 \mathrm{f}$. Dissertação (Mestrado em Biotecnologia e Recursos Naturais) - Universidade do Estado de Amazonas - UEA, Manaus, 2011.

CHAI, S. Y. et al. A thermotolerant endo-1,4- $\beta$-mannanase from Tricoderma virens UKM1: cloning, recombinant, expresssion and characterization. Journal of Biocatalysis B: Enzymatic, v. 125 , p. 49-57, 2015. 
CHAUHAN, P. S. et al. Mannanases: microbial sources, production, properties and potential biotechnological applications. Applied Microbiology Biotechnology, v. 93, n. 5, p. 1817-1730, 2012.

CHAUHAN, P. S. et al. Purification and characterization of an alkaline-termostable $\beta$ mannanase from Bacillus nealsonii PN and its application in mannoligosaccharides preparation having a prebiotic potential. European Food Research and Technology, v. 238, n. 6, p. 927-936, 2014.

CHANTORN, S. T. et al. Characterization of mannanase S1 from Klebsiella oxytoca KUBCW2-3 and its application in copra mannan hydrolysis. Scienci Asia, v. 39, p. 237-245, 2013.

CHANTORN, S. T. et al. Optimization of extracellular mannanase production from Penicillium oxalicum KUB-SN2-1 and application for hydrolysis properties. Journal of Science and Technology, v. 35, n. 1, p. 17-22, 2013.

CHEN, X. et al. Cloning, functional expression and characterization of Aspergillus sulphureus $\beta$-mannanase in Pichia pastoris. Journal of Biotechnology, v. 20, n. 3, p. 452-461, 2007.

CHENG, L. et al. Purification and characterization of a thermostable $\beta$-mannanase from Bacillus subtilis BE-91: Potential application in inflammatory diseases. BioMed Research International, v. 2016, n. 1, p. 1-7, 2016.

CHERUBINI, F. The biorefinery concept: using biomass instead of oil for producing energy and chemicals. Energy conversion and management, v. 51, n. 7, p. 1412-1421, 2010.

CLARKE, J. et al. A comparison of enzyme-aided bleaching of softwood paper pulp using combinations of xylanases, mannanase and $\alpha$-galactosidade. Applied Microbiology Biotechnology, v. 53, n. 6, p. 661-667, 2000.

CONCEIÇÃO, T. A. Estudo da produção de enzimas ligninolíticas por fungos agaricomycetes cultivados em resíduos agroindustriais do estado da Bahia. 2010. $92 \mathrm{f}$. Dissertação (Mestrado em Biotecnologia) - Universidade Estadual de Feira de Santana - UEFS, Bahia, 2010.

DOHERTY, W. O. S.; MOUSAVIOUN, P.; FELLOWS, C. M.; Vallue-adding to cellulosic ethanol: Lignin polymers. Industrial Crops and Products, v. 33, n. 2, p. 259-276, 2011.

DHAWAN, S.; KAUR, J.; Microbial mananases: an overview of production and applications. Critical Reviews in Biotechnology, USA, v. 27, n. 4, p. 197-216, 2007. 
DHAWAN, S. et al. A $\beta$-mannanase from Paenibacillus sp.: Optimization of production and its possible prebiotic potential. Biotechnology and Applied Biochemistry, v. 63, n. 5, p. 669678, 2015.

EMBRAPA AGROENERGIA, 2015. Disponível em:

http://ainfo.cnptia.embrapa.br/digital/bitstream/item/48750/1/biorrefinaria-modificado-web.pdf

EMBRAPA SOJA, 2017. Disponível em:

https://www.embrapa.br/soja

EL-SHAROUNY, E. E. et al. Optimization and purification of mannanase produced by an alkaliphilic-thermotolerant Bacillus cereus $\mathrm{N1}$ isolated from Bani Salama Lake in Waldi ElNatron. Biotechnoly \& Biotechnological Equipment, v. 29, n. 2, p. 315-323, 2015.

FERNANDO, et al. Biorefineries: current status, challenges, and future direction. Energy and Fuels, v.20, n. 4, p. 1727-1737, 2006.

FERREIRA FILHO, E. X.; PULS, H. COUGHLAN, M. P. Biochemical characteristics of two

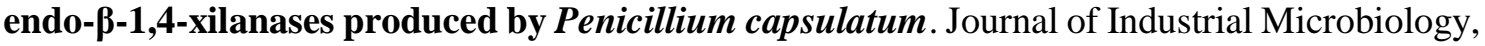
v. 11, n. 3, p. 171-180, 1993.

FREIESLEBEN, P. V. et al. An Aspergillus nidulans GH26 endo- $\beta$-mannanase with a novel degradation pattern on highly substituted galactomannas. Enzyme and Microbial Technology, v. 83, n. 0, p. 68-77, 2016.

GE, J. P. et al., Bio-chemical characterization of a $\beta$-mannanase from Bacillus licheniforms HDYM-04 isolated from flax water-retting liquid and its decolorization ability of dyes. RSC Advances, v. 6, n. 28, p. 23612-23621, 2016.

GHAFFAR, S. H.; FAN, M. Structural analysis for lignin characteristics in biomass straw. Biomass and Bioenergy, v. 57, n.1, p. 264-279, 2013.

GÍRIO, F. M. et al., Hemicelluloses for fuel ethanol: A review. Bioresource Technology, v. 101, n. 13, p. 4775-4800, 2010.

GOMES, H. A. R. Perfil e caracterização de holocelulases secretadas por Penicillium fellutanun com ênfase em mananase. 2014. 80 f. Dissertação (Mestrado em Biologia Microbiana) - Universidade de Brasília - UNB, Brasília, 2014.

GUMMADI, S. N.; PANDA, T. Purification and properties of microbial pectinases-a review. Process Biochemistry, v. 38, n. 7, 2003. 
HILGE, M. et al. Crystallization and preliminary crystallographic analysis of two $\boldsymbol{\beta}$ mannanase isoforms from Thermomonospora fusca KW3. Acta Crystallographica, v. D52, n. 6, p. 1224-1225, 1996.

HARHOLT, J.; SUTTANGKAKUL, A.; SCHELLER, H. V.; Biosynthesis of pectin. American Society of Plant Biologists, v. 153, n. 2, p. 384-395, 2010.

HARNPICHARNCHAI, P. et al. Production of high activity Aspergillus niger BCC4525 $\beta$ mannanase in Pichia pastoris and its application for manooligosaccharides production from biomass hydrolysis. Bioscienci, Biotechnology, and Biochemistry, v. 80, n. 12, p. 2298-2305, 2016.

HOWARD, et al. Lignocellulose biotechnology: issues of bioconversion and enzyme production. African Journal of Biotechnology, v. 2, n. 12, p. 602-619, 2003.

HERNÁNDEZ, J. A. Lignina organosolv de Eucalyptus dunni maiden, alternativa para a síntese de adesivos de poliuretano para madeira. 2007. $93 \mathrm{f}$. Tese (Doutorado em Engenharia Florestal) - Universidade Federal do Paraná - UFP, Curitiba, 2007.

HEMSWORTH, G. R. et al. Discovery and characterization of a new family of lytic polysaccharide monooxygenases. Nature Chemical Biology, v. 10, n. 2, p. 122-126, 2014.

HENRIKSSON, G.; JOHANSSON, G.; PETTERSSON, G. A critical review of celobiose dehydrogenases. Journal of Biotechnology, v. 78, n. 2, p. 93-113, 2000.

HORN, S. et al. Novel enzymes for the degradation of cellulose. Biotechnology for Biofuels, v. 5, n. 45, p. 1-12, 2012.

HUANG, Y. B.; FU, Y. Hydrolysis of cellulose to glucose by solid acid catalysts. Green Chemistry, v. 15, n. 5, p. 1095-1111, 2013.

INFANTE, J. C. M. Produção e caracterização de mananase de Aspergillus foetidus cultivado em casca do grão de soja. 2014. 72 f. Dissertação (Mestrado em Microbiologia) - Universidade de Brasília - UNB, Brasília, 2014.

INFANTE, J C. et al. Partial purification and characterization of a thermostable $\beta$-mannanase from Aspergillus foetidus. Applied Scienci, v. 5, n. 4, p. 881-893, 2015.

INOUE, H.; YANO, S.; SAWAYAMA, S.; Effect of $\boldsymbol{\beta}$-mannanase and $\boldsymbol{\beta}$-mannosidase supplementation on the total hydrolysis of softwood polysaccharides by the Talaromyces cellulolyticus celulase System. Applied Biochemistry Biotechnology, v. 176, n. 6, p. 1673-1686, 2015. 
JAYANI, R. S.; SAXENA, S.; GUPTA, R. Microbial pectinolytic enzymes: a review. Process Biochemistry, v. 40, n. 9, p. 2931-2944, 2005.

JARAMILLO, P. M. D. Produção, caracterização e aplicação biotecnológica de pectinases produzidas pelo fungo Aspergillus orizae cultivado em casca de maracujá-amarelo. 2014. 145 f. Tese (Doutorado em Biologia Molecular) - Universidade de Brasília - UNB, Brasília, 2014.

JUTURU, V.; WU, J. C. Microbial cellulases: engineering, production, and applications. Renewable and Sustainable Energy Reviews, v. 33, n. 1, p. 188-203, 2014;

KASHYAP, D. R. et al. Applications of pectinases in the commercial sector: a review. Bioresource Technology, v. 77, n. 3, p. 215-227, 2001.

KALAPATHY, U.; PROCTOR, A. Effect of acid extraction and alcohol precipitation conditions on the yield and purity of soy hull pectin. Food Chemical, v. 73, n. 4, p. 393-396, 2001.

KIRK, O.; BORCHERT, V.; FUGLSANG, C. C. Industrial enzyme applications. Current Opinion in biotechnology, v. 13, n. 4, p. 345-351, 2002.

KRISTENSEN, J. B. Enzymatic hydrolysis of lignocellulose: substrate interactions and high solids loadings. Forest and Landscap, Frederiksberg, n. 42, p. 130, 2009.

KRAUSS, U. et al. Mycoparasitism by Clonostachys byssicola and Clonostachys rosea on Trichoderma spp. from cocoa (Theobroma cacao) and implication for the design of mixed biocontrol agentes. Biological Control, v. 67, n. 3, p. 317-327, 2013.

KUBICEK, C. P. The structure of plant cell wall. In: KUBICEK, C. P. (Ed.) Fungi and lignocellulosic biomass. India: John Wiley e Sons, 2012. Chapter 1, p. 1-28.

KUMAGAI, Y. et al. Characterization of a calcium ion sensitive region for $\boldsymbol{\beta}$-mannanase from Streptomyces thermolilacinus. Biochimica et Biophysica Acta, v.1814, n. 9, p. 1127-1133, 2011.

LAEMMLI, U. K. Cleavage of structural proteins during the assembly of the head of Bacteriophage T4. Nature, v. 227, p. 680-685, 1970.

LEATHERBARROW, R. J. Enzfitter Manual, a Non-Linear Curve Fitting Program for Windows. Biosoft, 1999. 
LERMYTE, F.; SOBOTT, F. Eletron transfer dissociation provides higher-order structural information of native and partially unfolded protein complexes. Proteomics, v. 15, n. 16, p. 2813-2822, 2015.

LEVASSEUR, A. et al. Expansion of the enzymatic repertoire of the CAZy database to integrate auxiliary redox enzymes. Biotechnology for Biofuels, v. 6, n. 1, p. 9-14, 2013.

LI, H. et al. Secretory expression and characterization of a novel thermo-stable, salt-tolerant endo-1,4-p-mannanase of Bacillus subtilis WD23 by Pichia pastoris. European Food Research and Technology, v. 240, n. 4, p. 671-677, 2015.

LIAO, H. et al.; A new acidophilic thermostable endo-1,4- $\beta$-mannanase from Penicillium oxalicum GZ-2: cloning characterization and functional expression in Pichia pastoris. BMC Biotechnology, v. 14, n. 1, p. 2-12, 2014.

LIEPMAN, A. H. et al. Functional genomic analysis supports conservation of function among cellulose synthase-like a gene family members and suggests diverse roles of mannans in plants. Plant physiology, v. 143, n. 4, p. 1881-1893, 2007.

LIU, H. X. et al. Biochemical and characterization and cloning of an end- $\beta$-mannanase from bacillus subtilis YH12 with an unusually broad substrate profile. Process Biochemistry, v. 50, n. 5, p. 712-721, 2015.

LOPES, V. C. P. Recursos microbianos ligninolíticos: potencial para deslignificação e produção de Ligninases. 2016. 133 f. Tese (Doutorado em Microbiologia aplicada)) Universidade Estadual Paulista - UNESP, Rio Claro, 2016.

LU, H. et al. A novel thermophilic endo-ß-1,4- mannanase from Aspergillus nidulans XZ3: functional roles of carbohydrate-binding module and Thr/Ser- rich linker region. Applied Microbiology Biotechnology, v. 98, n. 5, p. 2155-2163, 2013.

LUO, H. et al. A novel highly acidic $\beta$-mannanase from acidophilic fungos Biospora sp. MEY-1: gene cloning and overexpression in Pichia Pastoris. Applied Microbiol Biotechnol, v. 82, n. 3, p. 453-461, 2009.

LYND, L et al. Microbial cellulose Utilization: fundamentals and biotechnology. Microbial and Molecular Biology Reviews, v. 66, n. 3, p. 506-577, 2002.

MAATSCH, J. M.; et al. Pectin content and composition from different food waste streams. Food Chemistry, v. 201, n. 1, p. 37-45, 2016.

MALGAS, S.; DYK, S. V.; PLETSCHKE, B. I.; A review of the hydrolysis of mannanas and synergistic interactions between $\beta$-mannanase, $\beta$-mannosidade and $\alpha$-galactosidase. Word Journal of Microbiology and Biotechnology, v. 31, n. 8, p.1167-1175, 2015. 
MALHERBE, S.; CLOETE, T. E. Lignocellulose biodegradation: Fundamentals and applications. Environmental Science and Biotecnology, v. 1, n. 2, p. 105-114, 2002.

MARTÍNEZ, A. T. et al. Biodegradation of lignocellulics: microbial, chemical, and enzymatic aspects of the fungal attack of lignin. Internationally Microbiology, v. 8, n. 3, p. 195-204, 2005.

MEHRI, M. et al. Effects os $\boldsymbol{\beta}$-mannanases on broiler performance, gut morphology and immune system. African Journal of Biotechnology, v. 9, n. 37, p. 6221-6228, 2010.

MICHEL, A. C. S. et al. Production of ethanol from soybean hull hydrolysate by osmotorelant Candida guilliermondii NRRL Y-2075. Bioresource technology, v. 99, n. 8, p. 2898-2904, 2008.

MIELENZ, J. R.; BARDSLEY, J. S.; WYMAN, C. E. Fermentation of soybean hulls to ethanol while preserving protein value. Bioresource Biotechnology, v. 100, n. 14, p. 3532-3539, 2009.

MHLONG, N. N. et al. A critical survey of average distances between catalytic carboxyl groups in glycoside hydrolases. Proteins, v. 82, n. 9, p. 1747-1755, 2014.

MILLER, G. L. Use of dinitrosalicylic acid reagent for determination of sugars. Analytical Chemistry, v. 31, n. 3, p. 426-428, 1959.

MORALES, E. V. Influência do fator de extração de café torrado e granulado e injeção de gás na formação de espuma no café solúvel tipo spray drier. 2014. 68 f. Dissertação (Tecnologia de Alimentos) - Universidade Tecnológica Federal do Paraná - UTFPR, Londrina, 2014.

MONTEIRO, V. N.; SILVA, R. N. Aplicações industrias da biotecnologia enzimática. In: Processos químicos: Aplicações industriais da biotecnologia enzimática. Goiânia: FIEG, 2009. Cap. 1, p. 9-23.

MOREIRA, L. R. S.; FERREIRA FILHO, E. X. An overview of mannan structure and mannan-degrading enzyme systems. Applied Microbiol Biotechnol, v. 79, n. 2, p. 165-178, 2008.

MOREIRA, L. R. S.; FERREIRA FILHO, E. Insights into the mechanism of enzymatic hydrolysis of xylan. Applied Microbiology and Biotechnology, v. 100, n. 12, p. 5205-5214, 2016.

MOREIRA, L. R. S.; MILANEZI, N. vG.; FERREIRA FILHO, E. X. Enzymology of pant cell wall breakdown: an update. In: BUCKERIDGE, M. S.; GOLDMAN, G. H. (Eds.) Routes to cellulosic etanol. New York: Spring Science, 2011. Chapter 6, p. 73-93. 
MOREIRA, L. R. S. Xilanases produzidas por Aspergillus terreus: Caracterização, degradação de biomassa lignocelulósica e efeitos de compostos fenólicos 2013. 297 f. Tese (Doutorado em Biolobia Molecular) - Universidade de Brasília - UNB, Brasília, 2013.

MOREIRA, G. M. Caracterização de espécies de Clonostachys byssicola e avaliação do parasitismo a Botrytis cinera. 2012. 83 f. Dissertação (Microbiologia Agrícola) - Universidade de Lavras - UFLA, Lavras, 2012.

NAGANAGOUDA, K.; SAlimATH, P. V.; MUlimani, V. H. Purification and characterization of endo- $\beta-1,4$ mannanase from Aspergillus niger gr for application in food processing Industry. Journal of Microbiology, v. 19, n. 10, p. 1184-1190, 2009.

NUNES, R. M. et al. Resíduos agroindustriais: potencial de produção de etanol de segunda geração no Brasil. Revista Liberato, v. 14, n. 22, p. 113-238, 2013.

PALIN, R.; GEITMAN, A. The role of pectin in plant morphogenesis. Bio Systems, v. 109, n. 3, p. 397-402, 2012.

PANGSRI, P. et al. Characterization of mannanase from Bacillus circulans NT 6.7 and its application in mannooligosaccharides preparation as prebiotic. Springer Plus, v. 4, n. 1, p. 2$11,2015$.

PARVATHY, K. S. et al. A simple non-aqueous method for carboxymethylation of galactomananas. Carbohydrates Polymers, v. 62, n.2, p. 137-141, 2005.

PÉREZ, J. et al. Biodegradation and biological treatments of cellulose, hemicellulose and lignin: an overview. International Microbiology, v. 5, n. 2, p. 53-63, 2002.

PIWPANKAEW, Y. et al. Cloning, secretory expression and characterization of recombinant 及-mannanase from Bacillus circulans NT 6.7. Springer Plus, v. 3, n. 1, p. 2-8, 2014.

POLLETO, P. Produção e avaliação de pectinases de Aspergillus niger LB-02-SF obtidos em biorreator de tambor rotativo. 2015. $139 \mathrm{f}$. Tese (Doutorado em Biotecnologia) - Universidade de Caxias do Sul - UCS - Caxias do Sul, 2015.

PRADEEP, G. C. et al. An extremely alkaline mannanase from Streptomyces sp. CS428 hydrolyzes galactomannan producing series of mannooligosaccharides. World Journal of Microbiology and Biotechnology, v. 32, n. 5, p. 84, 2016.

PURCHART, V. et al. Purification and chacacterization of two forms of endo- $\beta$-mannanases from a thermotolerant fungus, Aspergillus fumigatus IMI 385708 (formerly Thermomyces lanuginosus IMI 158749). Biochimica et Biophysica Act, v. 1674, n. 3, p. 239-250, 2004. 
RAGAUSKAS, et al. The path forward Biofuels and Biomaterial. Science, v. 311, n. 5760, p. 484-489, 2006.

REITER, W. D. Biosynthesis and properties of the plant cell wall. Current Opinion in Plant Biology, v. 5, n. 6, p. 536-542, 2002.

RODRIGUES, S. L. C. et al. Avaliação de parâmetros de ultrafiltração de suco de banana. Food Science and Technology, v. 23, p. 98-101, 2003.

RODRÍGUEZ GACIO, M. D. C. Softening-up mannan-rich cell walls. Journal of experimental botany, v. 63, n. 11, p. 3976-3988, 2012.

ROJAS, M. J.; Produção de etanol proteico da casca de soja. 2012. 93 f. Dissertação (Mestrado em Engenharia Bioquímica) - Universidade Federal de São Carlos - UFSCAR, São Carlos, 2012.

SAAD, S. M. I. Probióticos e prébióticos: o estado da arte. Revista de Ciências Farmacêuticas, v. 42, n, 1, p. 1-15, 2006.

SAMIR MA, A.; ALLOIN, F.; DUFRESNE, A. Review of recent research into cellulosic whiskers, their properties and their application in nanocomposite field. Biomacromolecules, v. 6, n.2, p. 612-626, 2005.

SANTOS, J. R. A.; GOUVEIA, E. R. Produção de bioetanol de bagaço de cana de açúcar. Revista Brasileira de Produtos Agroindustriais, v. 11, n. 1, p. 27-33, 2009.

SIIKA-AHO, M.; TENKANEN, M.; VIIKARI, L. Purification and characterization of two $\beta$ mannanases from Trichoderma reesi. Journal of Biotechnology, v. 29, n. 3, p. 229-242, 1993.

SCHÄFER, T. et al. Enzymes for technical applications. In: FAHNESTOCK, S. R.; STEINBÜCHEL, S. R. Biopolymers. Wiley VCH, 2005, Chapter 13, p. 377-437.

SCIUTO, D. L. Produção de holocelulases por Clonostachys byssicola cultivado em casca de soja - purificação parcial e caracterização de uma endoglicanases. 2015. 100 f. Dissertação (Mestrado em Microbiologia) - Universidade de Brasília - UNB, Brasília, 2015.

SCHROERS, H. J. et al. Classification of the Mycoparasite Gliocladium roseum in Clonostachys as $C$. rosea, Its Relationship to Bionectria ochroleuca, and Notes on Other Gliocladium-like Fungi. Mycology, v. 91, n. 2, p. 365-368, 1999.

SCHROERS, H. J. A monograph of Bionectria (Ascomycota, Hypocreales, Bionectriaceae) and its Clonostachys anamorph. 2015. 214 f. Monograph (Centraalbureau voor Schimmel cultures) - Utrecht, 2001. 
SCHRÖDER, R. et al. LeMAN4 endo-mannanase from ripe tomato fruit can act as mannan transglycosylation or hydrolase. Plant, v. 224, n. 5, p. 1091-1102, 2006.

SCHWARZE, F. W. M. R.; ENGELS, J.; MATTHECK, C. Fungal strategies of wood decay in trees. 2 nd. New York: Springer-Verlag Berlin Heidelberg, 2000.

SHIMIZU, M. et al. Novel $\beta$-mannanase belonging to a new glycoside hydrolase family in Aspergillus nidulans. Journal of Biological Chemistry, v. 290, n. 46, p. 3-34, 2015.

SIQUEIRA, F. G. et al. The potential of agro-industrial residues for production of holocellulose from filamentous fungi. International Biodegradation, v. 64, n. 1, p. 20-26, 2009

SIQUEIRA, F. G.; FERREIRA FILHO, E. X. Plant cell wall as a substrate for the production of enzymes with industrial application. Organic Chemistry, v. 7, n. 1, p.54-56, 2010.

SIQUEIRA, F. G. et al. Evaluation of holocellulase production by plant-degrading fungi grown on agroindustrial residues. Biodegradation, v. 21, n. 5, p. 85-824, 2010.

SONI, H. et al. Purification and characterization of $\beta$-mannanase from Aspergillus terreus and its applicability in depolymerization of mannans ams saccharification of lignocellulosic biomass. Biotech, v. 6, n. 2, p. 1-11, 2016.

SONI, H. et al. Screning, statistical optimized production and application of $\boldsymbol{\beta}$-mannanases from some newly isolated fungi. Engineering and Life Scienci, v. 16, n. 7, p. 1-30, 2016.

SONG, J. M. et al., Molecular cloning and characterization of a novel cold-active $\beta$ mannanase from the Antarctic springtail, Cryptopygus antarticus. Comparative Biochemistry and Physiology , v. 151, n. 1, p. 32-40, 2008.

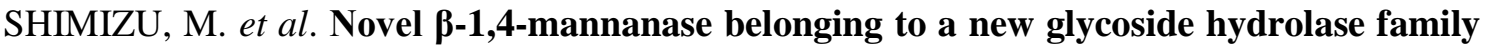
in Aspergillus nidulans. The Journal of Biological Chemistry, v. 290, n. 46, p. 27914-27927, 2015.

SHOBHA, M. S. et al. Modification of guar galactomannan with the aid of Aspergillus niger pectinase. Carbohydrate Polymers, v. 62, n. 3, p. 267-273, 2005.

SHOSEYOV, O.; SHANI, Z.; LEVY, I. Carbohydrate binding modules: biochemical properties and novel applications. Microbiology and Molecular Biology Reviews, v. 70, n. 2, p. 283-295, 2006.

SRIAMORNSAK, P. Chemistry of pectin and its pharmaceutical uses: a review. Silpakon University International journal, v. 3, n. 1, p. 206-228, 2003. 
SRIVASTAVA, P. K.; KAPOOR, M. Production, properties and applications of endo- $\beta$ mannanases. Biotechnology Advances, v. 35, n. 1, p. 1-19, 2016.

SRIVASTAVA, P. K. et al. Metal-dependent thermal stability of recombinant endomannanase (Man-1601) belonging to family GH 26 from Bacillus sp. CFR1601. Enzyme and Microbial Technology, v. 84, p. 41-49, 2016.

SRIVASTAVA, P. K; KAPOOR, M. Recombinant GH-26 endo-mannanase from Bacillus sp. CFR1601: Biochemical characterization and application in preparation of partially hydrolysed guar gum. Food Scienci and Technology, v 64, n. 2, p. 809-816, 2015.

STICKLEN, M. B. Plant genetic engineering for biofuel production: towards affordable cellulosic ethanol. Nature Reviews Genetics, v. 9, n. 6, p.433-443, 2008.

TAMARU, et al. Comparative genomics of the mesophilic cellulosome-producing Clostridium cellulovorans and its application to biofuel production via consolidated bioprocessing. Environmental Technology, v. 31, n. 8-9, p. 889-903, 2010.

TEWARI, R.; TEWARI R. P.; HOONDAL, G. S. Microbial pectinase. In: BARRETO, J. L. (Ed.) Microbial enzymes and biotransformations. Methods in Biotechnology, 2005, chapter 12, p. 191-2008.

TEJIRIAN, A.; XU, F. Inibiton off cellulose-catalysed lignocellulosic hydrolysis by iron and oxidation metal ions and complexes. Applied Enviromental Microbiology, v. 76, n. 23, p. 7673$7682,2010$.

TUOMELA, M. et al. Biodegradation of lignina in a compost environment: a review. Bioresource Technology, v. 72, n. 2, p. 169-183, 2000.

UENOJO, M.; PASTORE, G. M. Pectinases: aplicações industriais e perspectivas. Química nova, v. 30, n. 2, p. 388-394, 2007.

BRINK, V. D. J.; VRIES, R. P.; Fungal enzyme sets for plant polysaccharide degradation. Applied Microbiology and Biotechnology, v. 91, n. 6, p. 1477-1492, 2011.

VAN ZYL, et al. Fungal $\beta$-mannanases: mannan hydrolysis, heterologous production and biotechnological applications. Process Biochemistry, v. 45, n. 8, p. 1203-1213, 2010.

VANHOLME, R. et al. Lignin biosynthesis and structure. Plant Physiology, v. 153, n. 3, p. 895-905, 2010.

VANNUCE, A. L.; REZENDE, M. H. Anatomia vegetal: noções básicas. Goiânia: Adson Pereira Souza, 2003. 
VÁRNAI, A.; SIIKA-AHO, M.; VIIKARI, L. Carbohydrate-binding modules (CBMs) revisited: reduced amount of water counterbalances the need for CBMs. Biotechnology for Biofuels, v. 6, n. 1, p. 6-30, 2013.

VILLARREAL, M. O. et al. Plant cell wall polymers: function, structure and biological activity of their derivaties. In: GOMES, A. S. (Ed.) Polymerization. Kijeka: Intech, 2012. Chapter 4, p. 63-86.

WANG, Y. et al. Biochemical characterization of the novel endo- $\beta$-mannanase AtMan5-2 from Arabidopsis thaliana. Plant Science, v. 241, p. 151-163, 2015.

WANG, C. et al. Biochemical characterization of an acidophilic $\beta$-mannanase from Gloeophyllum trabeum CBS900.73 with significant transglycosylation activity and feed digesting ability. Food Chemistry, v. 197, p. 474-481, 2016.

WANG, C. et al., Biochemical characterization of a thermophilic $\beta$-mannanase from Talaromyces leycettanus JCM12802 with high specific activity. Applied Microbiology and Biotechnology, v. 99, n. 3, p. 1217-1228, 2014.

WEINGARTNER, V. Produção, purificação de mananase, obtida por fermentação no estado sólido utilizando casca de soja e Aspergillus niger. 2010. 161 f. Dissertação (Mestrado em Processos Biotecnológicos) - Universidade Federal do Paraná - UFP, Curitiba, 2010.

WILLFÖR, S. et al. Characterisation of water soluble galactoglucomannans from norway spruce wood and thermomechanical pulp. Carbohydrates Polymers, v. 52, n. 2, p. 175-187, 2003.

YAMABHAI, M. et al. Mannan biotechnology: from biofuels to health. Critical Reviews in Biotechnology, v. 36, n. 1, p. 32-42, 2014.

YANG, H. et al. A thermophilic $\beta$-mannanase from Neosartorya fischeri P1 whith broad pH stability and significant hydrolysis ability of various mannan polymers. Food Chemistry, v. 173, n. 1, p. 283-289, 2015.

YANG, M. et al. Characterization of an endo- $\beta$-mannanase from Enterobacter ludwigii MY271 and application in pulp industry. Bioprocess and Biosystems Engineering, v. 40, n. 1, p. 35-43, 2016.

YANG, W. et al. Biochemical characterization of the novel endo- $\beta$-mannanase AtMan5-2 from Arabidopsis thaliana. Plant Scienci, v. 254, n. 0, p. 151-163, 2015.

YU, S. et al. High-level expression and characterization of a thermophilic $\beta$-mannanase from Aspergillus niger in Pichia pastoris. Biotechnology Letters, v. 37, n. 9, p. 1853-1859, 2015. 
XIMENES, E. A.; FÉLIX, C. R. O sistema celulolítico de microrganismos anaeróbios: uma mini revião sobre celulossoma. Universitas Ciências da Saude, v. 1, n. 2, 2003.

XIMENES, E, A. A mannanase, ManA, of the polycentric anaerobic fungus Orpinomyces sp. Strain PC-2 has carbohydrate binding and docking modules, v. 51, n. 7, p. 558-568, 2005.

XIMENES, E. et al. Inhibition of cellulases by phenols. Enzyme and Microbial Technology, v. 46, n. 3-5, p. 170-176, 2010.

ZAMBOM, M. A. et al. Valor nutricional da casca do grão de soja, farelo de soja milho moído e farelo de trigo para bovinos. Revista Brasileira de Zootecnia, Viçosa, v. 38, n. 11, p. 937-946, 2001.

ZHENG, H. et al. High level extracelular production of a truncated alcaline $\boldsymbol{\beta}$-mannanases from alkaliphilic Bacillus sp. N16-5 in Escherichia coli by the optimization of induction condition and fed-batch fermentation. Journal of Industrial Microbiology \& Biotechonology, v. 43, n. 7, p. 977-987, 2016.

ZHANG, Y. H.; LYND, L. R. Toward an aggregated understanding of enzymatic hydrolysis of cellulose: noncomplexed cellulose systems. Biotechnol and Bioengineering, v. 88, n. 7, p. 797-824, 2004.

ZHANG, R. et al. Molecular and biochemical characterizations of a new low-temperature active mannanase. Folia Microbiologica, v. 60, n. 6, p. 483-492, 2015.

ZHOU, J. et al. Novel low-temperature-active, salt tolerant and resistant endo-1,4-pmannanase from a new Shingomonas strain. Journal of Bioscience and bioengineering, v. 113, n. 5 , p. 568-574, 2012.

ZHOU, H. et al. N-terminal truncation contributed to increasing termal stability of mannanase Man1312 withou activity loss. Journal of the Scienci of Food and Agriculture, v. 96, n. 4, p. 1390-1395, 2015.

ZHOU, H. et al. Mannanase Man23 mutants library construction basing on a novel cell-free protein expression. System. Journal of the Scienci of Food and Agriculture, v. 94, n. 13, 2016. 